\title{
Assessing and Managing Rapid Credit Growth and the Role of Supervisory and Prudential Policies
}

Paul Hilbers, Inci Otker-Robe, Ceyla Pazarbasioglu, and Gudrun Johnsen 


\title{
IMF Working Paper
}

Monetary and Financial Systems Department

\section{Assessing and Managing Rapid Credit Growth and the Role of Supervisory and Prudential Policies}

Prepared by Paul Hilbers, Inci Otker-Robe, Ceyla Pazarbasioglu, and Gudrun Johnsen ${ }^{1}$

July 2005

\begin{abstract}

\section{This Working Paper should not be reported as representing the views of the IMF.} The views expressed in this Working Paper are those of the author(s) and do not necessarily represent those of the IMF or IMF policy. Working Papers describe research in progress by the author(s) and are published to elicit comments and to further debate.

This paper reviews trends in bank lending to the private sector, with a particular focus on Central and Eastern European countries, and finds that rapid growth of private sector credit continues to be a key challenge for most of these countries. The paper discusses possible implications for economic and financial stability and the policy options available to counter and reduce these risks. It argues that the authorities will need to focus on the implications for both the macro economy and the financial system and, depending on their assessment, may need a comprehensive policy response comprising a mix of macro and prudential policies. In particular where there are limitations to the effective use of monetary and fiscal measures, supervisory and prudential policy responses will have a key role in addressing financial stability concerns.
\end{abstract}

JEL Classification Numbers: E44, E51, G21

Keywords: credit growth, financial stability, supervisory and prudential policies

Author(s) E-Mail Address: philbers@imf.org, iotker@imf.org, cpazarbasioglu@imf.org, gjohnsen@imf.org

\footnotetext{
${ }^{1}$ The authors are grateful for comments from Marta Castello-Branco, Sean Craig, Charles Enoch, Tonny Lybek, Marcel Peter, Susan Schadler, Marco Terrones, Jan-Willem van der Vossen and Maxwell Watson. The paper has also benefited from comments from participants attending a Monetary and Financial Systems Department seminar at the International Monetary Fund. Nada Oulidi provided useful research assistance at the initial stages of this project.
} 


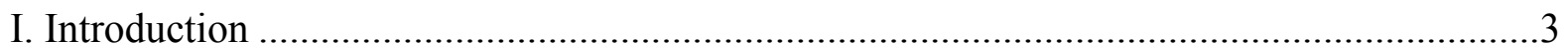

II. Analysis of Rapid Credit Growth.................................................................................

III. Country Experiences with Rapid Credit Growth .....................................................6

A. Recent Developments in Credit Growth in the CEE Countries ............................8

B. Country Experiences with Lending Booms and Implications for CEE Countries..12

IV. Policy Responses to Rapid Credit Growth in the CEE Countries .................................21

A. Measures Taken in Response to Rapid Credit Expansion ..................................23

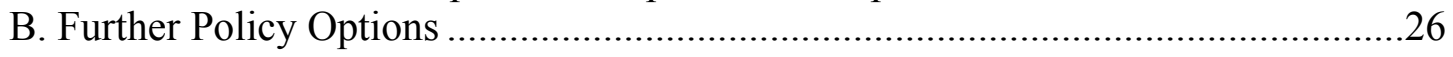

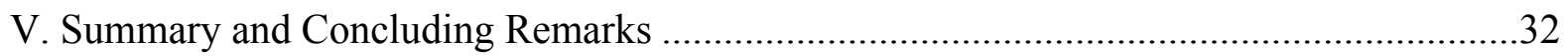

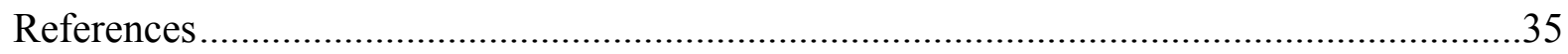

Tables

1. Components of the Analysis of Rapid Credit Growth ..................................................8

2. Growth of Private Sector Credit in Eastern and Central European Countries ......................9

3. Bank Credit to the Private Sector (BCPRS) during Credit Boom Episodes....................... 14

4. Selected Financial Indicators for the CEE Countries with the Fastest Growth of Credit....22

5. Policy Responses to Rapid Credit Growth in Selected CEE Countries............................25

6. Key Risks Associated with Credit Growth ..............................................................29

7. Prudential and Supervisory Measures to Manage Key Risks of Rapid Credit Growth ........30

Figures

1. CEE Countries: Real Credit Growth over 2000-04 vs. Credit to GDP in 1999.................11

2. Real Private Sector Credit Growth and Financial Deepening in the CEE Countries ..........11

3. Macroeconomic Developments during Credit Boom Episodes .....................................16

4. CEE Countries: Funding of the Credit Growth..........................................................19

5. Menu of Policy Options in Responding to Rapid Credit Growth ...................................24

Boxes

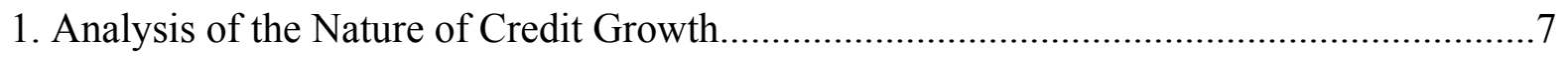

Appendices

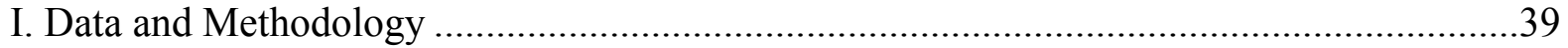

II. The Nature of Credit Growth in the Group of Countries with Rapid Credit Growth .........42

III. Policy Options to Cope with Rapid Credit Growth ....................................................45

IV. Measures Used to Deal with Credit Growth in Selected European Countries ..................54 


\section{INTRODUCTION}

This paper discusses the phenomenon of rapid growth in bank credit to the private sector, which in recent years has been particularly prominent in many Central and Eastern European countries as well as countries to the East and South of the European Union (a group henceforth referred to as "CEE"). In the past few years, real growth rates of credit to the private sector in these countries were often in the range of 30-50 percent per annum, albeit beginning from a low base. This trend has generally been viewed as a normal and positive consequence of the growing degree of deepening and restructuring of the financial system. It fits in with the transition process from centrally planned to market-based economies and has often been supported by the prospect of European Union (EU) accession. At the same time, however, there are growing concerns about the implications for macroeconomic and financial stability, in particular where rapid credit growth has coincided with a weakening current account and vulnerabilities in the financial systems.

The paper reviews the trends in bank lending to the private sector in CEE countries; identifies episodes and cases of rapid credit growth; discusses possible implications for macroeconomic and financial stability; and discusses the pros and cons of a number of instruments - both macroeconomic and prudential in nature - that could be used to counter and reduce these risks, drawing on country experiences. It is by no means the first study on this topic ${ }^{2}$, and it focuses in particular on developments in the most recent years, which have often shown a further acceleration of credit growth. The distinctive feature of this paper is that it concentrates on the supervisory and prudential implications of rapid credit growth, and on how prudential and supervisory policies could be used in strengthening the resistance of the financial system to adverse consequences of rapid credit expansion. These prudential and supervisory aspects, and their relationship to macroeconomic policy responses as part of an overall policy mix, have received less attention in the literature.

The paper is organized as follows. Section II discusses the possible factors underlying rapid growth of credit and the implications for macroeconomic and financial stability. Section III provides a brief summary of recent developments in bank credit in the CEE countries and, drawing on stylized facts on the behavior of selected macroeconomic and financial variables during episodes of rapid credit growth internationally, discusses the implications for CEE economies. Section IV discusses the wide variety of possible policy responses, with greater focus on prudential and supervisory measures. Concluding remarks follow in Section V.

\section{Analysis of RAPID Credit Growth}

This section provides a brief overview of the factors underlying a rapid expansion of bank credit to the private sector and its possible implications for macroeconomic and financial stability. It establishes a framework to analyze a credit growth process by providing a menu of indicators of vulnerability that could be examined and monitored to assess the possible risks.

2 See also Cottarelli, Dell' Ariccia, and Vladkova-Hollar (2003), Schadler and others (2004), Maechler and Swinburne (2005), International Monetary Fund (2004a), and Watson (2004). 
The literature generally identifies three main drivers of rapid credit growth: ${ }^{3}$

- During the development phase of an economy, credit grows more quickly than output (Favara, 2003; King and Levine, 1993; and Levine, 1997). This "financial deepening" argument is supported by empirical work suggesting that a more developed financial sector helps promote economic growth.

- Credit expands more rapidly than output at the beginning of a cyclical upturn due to firms' investment and working capital needs, according to the conventional accelerator models (see, e.g., Fuerst, 1995; and International Monetary Fund, 2004a).

- $\quad$ Excessive credit expansions may result from inappropriate responses by financial market participants to changes in risks over time. According to the "financial accelerator models" in capital inflows, increases collateral values (increases the relative price of nontradables), and allows firms and households to borrow and spend. If performance falls below these expectations, asset prices and collateral values decline. This reverses the financial accelerator, increasing the indebtedness of the borrowers, decreasing both their capacity to service their loans and their access to new loans. These factors play an important role in extending a boom and increasing the severity and length of a downturn.

In practice, it has proven difficult to distinguish among these three factors driving credit growth and to determine a "neutral" level or rate of growth for credit. ${ }^{5}$ When assessing rapid credit growth, it is therefore necessary to carefully consider the potential implications for macroeconomic stability. A rapid expansion of bank credit to the private sector may affect macroeconomic stability by stimulating aggregate demand compared to potential output and creating overheating pressures, as bank lending fuels consumption and/or import demand, with subsequent effects on the external current account balance, inflation, and currency stability. A continued deterioration in the current account deficit may in turn trigger a cutback of external credit lines and foreign liquidity and thus lead to a deterioration of the condition of the banking system, bringing about a full-fledged financial and economic crisis.

\footnotetext{
${ }^{3}$ See, for example, International Monetary Fund (2004a) and Gourinchas, Valdes, and Landerretche (2001).

${ }^{4}$ See Bernanke and Gertler (1995), Bernanke, Gertler and Gilchrist (1999), Borio, Furfine and Lowe (2001), Kindleberger (1996), Kiyotaki and Moore (1997), and Minsky (1992).

${ }^{5}$ Cottarelli, Dell'Ariccia, and Vladkova-Hollar (2003) estimate an equation for bank credit to the private sector as a function of public debt, per capita income, inflation, financial liberalization, and the legal system, and they use this equation to determine an equilibrium level with which actual levels can be compared. They note, however, that the ongoing transition process in these countries complicates the determination of a "normal" growth rate, and that the focus on aggregate credit developments may lead to an underestimation of risks.
} 
Rapid credit growth also has implications for financial stability. There is a large body of literature that links credit overexpansion and banking crises. ${ }^{6}$ Kaminsky, Lizondo, and Reinhart (1997), in a survey of the literature, report that five out of seven studies find credit growth to be an important determinant of banking and/or currency crises. Goldstein (2001) provides evidence on the link between a credit boom and the likelihood of twin crises (banking and currency crises) as a result of capital flows. Similarly, a recent study (International Monetary Fund, 2004a) concludes that credit booms pose significant risks for emerging market countries, as they are generally followed by sharp economic downturns and financial crises. In a broad sample of boom episodes over forty years, lending booms are often found to be associated with a domestic investment boom, an increase in domestic interest rates, a worsening of the current account, a decline in international reserves, a real appreciation of the exchange rate, and a fall in growth of potential output. About three-fourths of credit booms are shown to be associated with a banking crisis and almost seven-eighths with a currency crisis.

The macroeconomic and microeconomic implications of rapid credit growth are interrelated. On the one hand, in a situation of continued macroeconomic deterioration (inflation and/or external imbalances), financial stability will likely also deteriorate. For example, macroeconomic imbalances impact the stability of the financial system as the repayment capacity of borrowers may worsen with the slowdown in economic activity and the movements in interest and exchange rates associated with the macroeconomic instability. On the other hand, concerns about financial sector health may lead to macroeconomic instability, as markets react to such concerns by adjusting investment portfolios, including holdings of currencies.

These risks are generally underestimated during booms due to measurement difficulties both in forecasting overall economic activity and its link with credit losses, and in assessing how correlations of credit losses across borrowers and lenders change over time. This underestimation of risk may result in overoptimism about the degree of structural change that may be fueling the credit growth and a socially suboptimal reaction to risk by market participants. Incentive structures that reward short-term performance further contribute to credit growth even if risk is measured properly. Certain accounting and regulatory frameworks may also encourage or lead to lending decisions that may contribute to financial system vulnerability. Moreover, rapid credit growth may result from certain micro- or bank-level factors that create incentives for banks to take on excessive risk, including moral hazard arising from implicit or explicit government guarantees or inappropriate governance structures.

The banks' ability and resources to monitor and manage risks are also stretched by the increased volume and speed of credit expansion. Substandard loan-granting procedures and unrealistic projections of future repayment capacity of borrowers may distort the growth and allocation of credit. Such exuberance would allow large exposures to develop, which could

\footnotetext{
${ }^{6}$ See Demirguc-Kunt and Detragiache (1997), Drees and Pazarbasioglu (1995), Goldfajn and Valdes (1997), Goldstein (2001), Gourinchas, Valdes and Landerretche (2001), Kaminsky, Lizondo, and Reinhart (1997), and Kaminsky and Reinhart (1999).
} 
magnify real sector costs in the event of a shock. Governance issues related to insider or connected lending may be aggravated under these circumstances. Apart from developments in the amount of credit, the nominal increase in the number of loans is a relevant factor, also in terms of the ability of the banks and supervisors to assess credit quality. Banks need to have sufficiently trained credit assessors to determine which credit requests should be honored. However, even if the assessors are skilled, the sheer number of credit applications in an upswing may be so large that the existing staff cannot handle them. In that case, requests that should not be considered may be accepted. Credit bureaus may help to alleviate the problems but may not always be established or functioning properly.

The inter-relationship between macroeconomic and financial sector stability suggests that in determining the risk profile of and policy responses to rapid credit growth, a more detailed analysis of its characteristics is important. When it has been determined that bank credit to the private sector is growing at a rapid pace, there will be a need to collect and monitor more detailed information about this process. No less important are to have a detailed breakdown of aggregated credit data according to the borrower and to have information on the purpose, use, and specific features of the loans. All these aspects are relevant to assess the risks and to determine the best policy response, since the magnitude of losses in the event of an adverse shock will depend on the degree of maturity mismatches, the sectoral composition and concentration of credit, the relative importance of collateral-based lending, the currency exposure of banks and borrowers, the availability of hedging instruments, and the extent to which banks and borrowers use these instruments to cover their exchange and interest rate risks. Box 1 further discusses the various ways to assess the nature of credit growth.

More generally, assessing risks associated with rapid credit growth involves a comprehensive analysis of the stability of the macro economy and the financial system (Table 1). Such an assessment includes a variety of relevant macroeconomic and financial sector data (financial soundness indicators and structural financial sector data), as well as information from stress tests and scenario analyses to determine the sensitivity of the financial system to macroeconomic and market shocks (International Monetary Fund, 2005a). Real estate developments require special attention, as indicated above. Market-based information complements the financial sector data by conveying market perceptions of the health and stability of the financial system. Information on the quality of the institutional and regulatory frameworks, mostly through assessments of the compliance with international financial sector standards, helps in interpreting and assessing developments in prudential variables.

\section{COUNTRY EXPERIENCES WITH RAPID CREDIT GROWTH}

Given the framework suggested in Section II, this section assesses the challenges associated

with the continuing rapid credit growth to the private sector in some of the CEE countries. The first subsection provides an overview of the recent developments regarding credit growth in $\mathrm{CEE}$ countries and finds that credit to the private sector continues to grow at a very rapid pace in many of these countries. In the following subsection, the experience of CEE countries is compared with that of other countries that have experienced credit booms, with a particular 


\section{Box 1. Analysis of the Nature of Credit Growth}

In determining the risk profile of, and policy response to, rapid credit growth, a more detailed analysis of its characteristics is important. Such analysis would include a detailed breakdown of aggregated credit data according to the borrower, the purpose and use of the loans, their sectoral composition and concentration, the currency denomination, and the maturity and other conditions of the loans.

In terms of the breakdown of credit data, a key element is the type of borrower, in particular, the distinction between households and the corporate sector. Households tend to borrow for purchases of durable consumer goods (e.g., cars) or for real and financial assets. Consumer loans are generally relatively small; there may be substantial risks involved on a case-by-case basis, but the overall risk is diversified due to the large number of the debtors. There have been few cases where rapid expansion of consumer loans has led to systemic problems. Household borrowing for purchases of assets has a very different risk profile. Mortgage lending and lending for equity purchases involve higher amounts - in the case of real estate lending, often a multiple of the household's income - but are generally supported by collateral. Key variables in assessing the risks are loan-to-value ratios, the effectiveness of collateral legislation, and the financial health of the borrowers. With regard to the latter, it is important to closely monitor the overall balance sheet of the household sector and in particular the degree of indebtedness in relation to disposable income. But these indicators may not be sufficient to detect asset price bubbles, and therefore a careful analysis of the relationship between asset prices and, in particular, rates of return on assets may be needed in cases where bubbles are suspected. With regard to corporate loans, the risk of the latter is increased by weaknesses in transparency, accounting, contract enforcement etc., to an extent that in some countries lending to households (for which these problems are not so serious) can actually be less risky.

Within the corporate sector, it is useful to conduct a sectoral breakdown of the borrower. A distinction between various sectors (agriculture, manufacturing, construction, services, etc.) is useful to determine the likely character and purpose of the loan-e.g., whether the credit provided will be used for productive economic activities. A careful analysis of sectoral balance sheets and financial results plays a key role in assessing corporate sector credit risk. In addition, it may be relevant to include the ownership of the industry sector as a relevant factor, distinguishing between credit to state-owned enterprises, domestic private enterprises, and foreign-owned industries.

The currency denomination is another key factor in assessing rapid credit growth. Borrowing in foreign currency is generally driven by lower foreign interest rates compared to domestic rates. The main risk is related to the exchange rate. Banks are generally constrained by limits on open foreign exchange positions, which forces them to fund these credits in foreign currency as well, e.g., through foreign currency deposits, credit lines with the banks' foreign owner, or other borrowing from abroad. But their customers may not be hedged, hence it will be important to assess whether the borrower has foreign exchange income that can be used to repay the debt and/or whether hedging instruments are available and used. Even if the banks are fully covered against currency risk, the exchange rate risk for their clients may translate into sizeable credit risk for the banking sector.

Other relevant factors include maturity, interest rate conditions, and collateral. When maturities are short, repayment problems surface at an early stage, unless evergreening practices are widespread. In general, maturities in emerging markets will tend to be shorter than in fully developed markets, due to a lack of available long-term funding. For the same reason, interest rate fixation periods will tend to be shorter. If expectations of interest rate declines prevail, unexpected interest rate increases may result in debt servicing problems for debtors. Collateral - if it can readily be accessed and used to cover defaults - reduces the risk for financial institutions and creates an incentive for debtors to meet their obligations. It may, however, also exacerbate cycles in real estate lending.

More generally, rapid credit growth and real estate market developments are often closely related, which makes close monitoring of the latter essential in assessing credit growth. Booms and busts in asset prices (in particular for real estate) can contribute to unbalanced credit growth, resulting in financial sector distress and macroeconomic imbalances. There are various channels through which real estate cycles and bubbles can develop. Optimistic investors may drive up prices since the supply reaction is slow due to lags in construction. Cycles can be exacerbated by the use of real estate as collateral for financing, and by financial institutions' capital gains on their own holdings of real estate, which increase their ability to lend. In addition, financial sector liberalization can extend the sector's ability to finance real estate transactions in an environment of potentially insufficient credit assessment skills. A lack of good quality and timely data on real estate developments, however, can complicate assessing the risks associated with real estate market developments. ${ }^{1}$

${ }^{1}$ On the specifics of real estate markets and related measurement issues, see Hilbers, Lei, and Zacho (2001), Sundararajan and others (2002), and Bank for International Settlements (2005). 
Table 1. Components of the Analysis of Rapid Credit Growth

\begin{tabular}{|c|c|}
\hline Key data & Provide information on \\
\hline $\begin{array}{l}\text { Macroeconomic data } \\
\text { (inflation, current account, etc.) }\end{array}$ & Pending macro risks or vulnerabilities \\
\hline $\begin{array}{l}\text { Financial Soundness Indicators } \\
\text { (capital, asset quality, earnings, liquidity) }\end{array}$ & Soundness and resilience of the financial sector \\
\hline Sectoral balance sheets & Corporate sector debt and earnings \\
\hline (corporate sector, households) & Household sector indebtedness \\
\hline $\begin{array}{l}\text { Stress tests of the financial system } \\
\text { (sensitivity of balance sheets to shocks) }\end{array}$ & $\begin{array}{l}\text { Vulnerability to changes in key macro and } \\
\text { market variables }\end{array}$ \\
\hline $\begin{array}{l}\text { Real estate market developments } \\
\text { (price developments, rents, vacancy levels, etc.) }\end{array}$ & $\begin{array}{l}\text { Unbalanced developments and potential bubbles } \\
\text { in the market }\end{array}$ \\
\hline $\begin{array}{l}\text { Other market data } \\
\text { (stock prices and yields, credit ratings) }\end{array}$ & $\begin{array}{l}\text { The markets' expectations about future risks and } \\
\text { returns }\end{array}$ \\
\hline $\begin{array}{l}\text { Structural financial sector information } \\
\text { (size, ownership, concentration, legal framework) }\end{array}$ & $\begin{array}{l}\text { Risks of contagion and owner's obligation and } \\
\text { ability to control such risks }\end{array}$ \\
\hline $\begin{array}{l}\text { Qualitative information } \\
\text { (compliance with financial sector standards) }\end{array}$ & $\begin{array}{l}\text { Quality of data (transparency) and of supervision } \\
\text { and regulation of markets and institutions }\end{array}$ \\
\hline
\end{tabular}

emphasis on those countries that have experienced crises in the aftermath of credit booms and on the countries experiencing credit booms that have adopted the euro (henceforth called "euro-convergence countries," including Greece, Ireland, Portugal, and Spain). The section concludes with an assessment of the emergence of risks as a result of the ongoing credit booms in the CEE countries.

\section{A. Recent Developments in Credit Growth in the CEE Countries}

Many of the CEE countries have been experiencing a rapid expansion of bank credit to the private sector in recent years. This process, which was already apparent at the beginning of this decade, has only become stronger since. ${ }^{7}$ During 2000-04, credit increased by about 17 percent a year on average in real terms across the region (Table 2). ${ }^{8}$ In 2004, credit to

${ }^{7}$ In all the countries that had been identified as "early risers" in Cottarelli, Dell'Ariccia, and Vladkova-Holar (2003), with the exception of Croatia and Poland, credit continues to rise at a rapid pace (Bulgaria, Estonia, Hungary, Latvia, and Slovenia). Some of the "sleeping beauties" (Albania and Romania, and lately the Czech and Slovak Republics) seem to have woken up, while in "late risers" (Bosnia and Herzegovina, Serbia and Montenegro, and Lithuania), real growth of credit has continued to rise.

${ }^{8}$ This paper focuses on bank credit to the private sector, excluding bank credit extended to the public sector and credit extended by nonbank financial institutions for which data availability is limited. Breakdown of credit between foreign and domestic currency denominated components is also not available across all countries in the sample, and hence no attempt has been made to treat them separately in the analyses. Moreover, the credit growth figures used in the analyses were all obtained from International Financial Statistics for purposes of comparability and may differ from those of the national authorities. 
Table 2. Growth of Private Sector Credit in Eastern and Central European Countries (in percent)

\begin{tabular}{lllllll}
\hline & & Average & Cumulative Change \\
\end{tabular}

Real Growth of Credit

Countries with real credit growth higher than the sample average (16.8\%)

$\begin{array}{lrrrrrr}\text { Ukraine } & 32.9 & 25.5 & 48.8 & 55.7 & 21.6 & 36.9 \\ \text { Latvia } & 28.1 & 33.5 & 34.3 & 41.2 & 41.1 & 35.6 \\ \text { Albania } & 33.9 & 38.9 & 25.6 & 23.0 & 28.5 & 30.0 \\ \text { Bulgaria } & 6.0 & 23.0 & 34.6 & 45.4 & 40.5 & 29.9 \\ \text { Lithuania } & -7.0 & 4.9 & 30.1 & 60.8 & 38.1 & 25.4 \\ \text { Russia } & 27.2 & 25.1 & 12.3 & 27.4 & 34.0 & 25.2 \\ \text { Belarus } & 6.8 & 8.3 & 16.2 & 43.8 & 36.1 & 22.2 \\ \text { Estonia } & 7.4 & 12.1 & 15.6 & 30.9 & 39.5 & 21.1 \\ \text { Moldova } & 6.1 & 26.2 & 31.0 & 29.8 & 7.9 & 20.2 \\ \text { Hungary } & 30.3 & 8.0 & 13.6 & 27.4 & 11.2 & 18.1\end{array}$

Countries with real credit growth lower than the sample average (16.8\%)

$\begin{array}{lrrrrrr}\text { Croatia } & 1.4 & 17.2 & 27.5 & 13.1 & 11.3 & 14.1 \\ \text { Romania } & -10.2 & 16.5 & 14.2 & 23.7 & 18.9 & 12.6 \\ \text { Slovenia } & 7.6 & 9.6 & 5.2 & 9.3 & 16.0 & 9.5 \\ \text { Bosnia } & 0.7 & -26.7 & 27.3 & 19.5 & 14.9 & 7.1 \\ \text { Macedonia } & -9.0 & -7.3 & 2.3 & 14.0 & 24.0 & 4.8 \\ \text { Poland } & 5.8 & 1.9 & 2.4 & 5.8 & 0.1 & 3.2 \\ \text { Czech Republic } & -9.7 & -15.0 & -22.8 & 8.5 & 10.3 & -5.8 \\ \text { Slovak Republic } & -7.1 & -26.2 & 10.9 & -19.8 & -0.4 & -8.5 \\ \text { Sample Average } & \mathbf{8 . 4} & \mathbf{9 . 7} & \mathbf{1 8 . 3} & \mathbf{2 5 . 5} & \mathbf{2 1 . 9} & \mathbf{1 6 . 8}\end{array}$

\section{Credit-to-GDP Ratio}

Countries with real credit growth higher than the sample average (16.8\%)

$\begin{array}{lrrrrrrr}\text { Ukraine } & 11.1 & 12.9 & 17.5 & 24.3 & 24.9 & 18.1 & 16.4 \\ \text { Latvia } & 17.2 & 21.3 & 26.5 & 34.6 & 45.4 & 29.0 & 30.9 \\ \text { Albania } & 4.6 & 5.9 & 7.3 & 8.4 & 9.9 & 7.2 & 6.0 \\ \text { Bulgaria } & 12.6 & 14.9 & 19.6 & 27.4 & 36.7 & 22.2 & 24.6 \\ \text { Lithuania } & 11.4 & 11.4 & 14.0 & 20.4 & 25.6 & 16.6 & 12.8 \\ \text { Russia } & 13.3 & 16.5 & 17.7 & 21.0 & 24.5 & 18.6 & 11.5 \\ \text { Belarus } & 8.8 & 8.2 & 8.9 & 11.9 & 13.9 & 10.3 & 4.7 \\ \text { Estonia } & 23.9 & 25.2 & 26.9 & 33.1 & 43.3 & 30.5 & 19.0 \\ \text { Moldova } & 12.6 & 14.7 & 17.1 & 20.5 & 21.3 & 17.3 & 9.5 \\ \text { Hungary } & 32.4 & 33.7 & 35.8 & 43.0 & 46.0 & 38.2 & 19.9\end{array}$

Countries with real credit growth lower than the sample average (16.8\%)

$\begin{array}{lrrrrrrr}\text { Croatia } & 37.2 & 42.2 & 50.7 & 54.2 & 57.5 & 48.4 & 20.3 \\ \text { Romania } & 7.2 & 7.7 & 8.3 & 9.5 & 10.0 & 8.5 & 2.0 \\ \text { Slovenia } & 36.4 & 38.4 & 38.9 & 41.5 & 46.3 & 40.3 & 12.4 \\ \text { Bosnia } & 43.3 & 30.1 & 36.3 & 41.4 & 45.2 & 39.2 & -0.6 \\ \text { Macedonia } & 17.8 & 17.6 & 17.7 & 19.5 & 23.6 & 19.3 & 2.8 \\ \text { Poland } & 27.3 & 27.9 & 28.4 & 29.0 & 27.7 & 28.1 & 1.7 \\ \text { Czech Republic } & 47.9 & 39.6 & 29.8 & 30.7 & 32.2 & 36.0 & -21.1 \\ \text { Slovak Republic } & 51.3 & 37.6 & 39.6 & 31.6 & 30.6 & 38.1 & -23.9 \\ \text { Sample Average } & \mathbf{2 3 . 1} & \mathbf{2 2 . 5} & \mathbf{2 4 . 5} & \mathbf{2 7 . 9} & \mathbf{3 1 . 4} & \mathbf{2 5 . 9} & \mathbf{8 . 3}\end{array}$

Source: International Financial Statistics, World Economic Outlook and IMF staff calculations.

1/ Percentage point difference between figures for 2004 and 1999. 
the private sector increased by about 30-45 percent in real terms in six of the countries in the region. In a number of countries, growth continued at an unabated pace (Belarus, Bulgaria, Estonia, Latvia, and Russia), while in others (Hungary, Lithuania, Moldova, and Ukraine), the pace started to decelerate somewhat from early 2004, albeit remaining at high rates. As a result, the ratio of private sector credit to GDP has also been increasing significantly in these countries, albeit from a low base. ${ }^{9}$

This expansion in credit occurred at relatively low levels of financial intermediation, providing support for the "catching-up" hypothesis. With the exceptions of Estonia and Hungary, the countries with the fastest growth in private sector credit had credit-to-GDP ratios below the group average of 22 percent (compared to the average for the EU-15 countries of over 100 percent of GDP) (Figures 1 and 2). In contrast, in those countries where the real credit growth has been relatively low, the credit-to-GDP ratio has been generally above the group average (except in Macedonia and Romania). ${ }^{10}$

Rapid credit growth in the region has been supported by a general easing of monetary conditions and improved economic prospects. Consistent with the "overoptimism" argument discussed in Section II, favorable economic conditions, combined with macroeconomic stability and progress in financial sector reforms, have led to an upward revision in income expectations of the private sector. Consequently, strong consumption and investment in a number of these economies has emerged (e.g., Bulgaria, Estonia, Latvia, Lithuania, and Romania), thereby increasing credit demand. For some of the countries in the region, EU prospects and convergence expectations also played a role in the pace of credit expansion.

Also, in a number of countries, incentives created by the prevailing monetary and exchange rate policy mix, as well as fiscal or quasi-fiscal policies, may have stimulated certain types of bank credit. For example, in many of these countries, exchange rate regimes are characterized by pegged or tightly predictable exchange rates. ${ }^{11}$ Combined with wide interest rate margins in the domestic market, predictable exchange rates may have created incentives for borrowing in foreign currencies (by banks and/or borrowers) and led to capital inflows that help stimulate credit expansion. On the fiscal side, open-ended government interest rate subsidies may have stimulated the growth of consumption lending, for example in Hungary; in Estonia, interest rate deductibility of mortgage loans created real estate borrowing incentives; and in Belarus, government guarantees to support bank loans rose sharply in 2004.

\footnotetext{
${ }^{9}$ See also Cottarelli, Dell'Ariccia, and Vladkova-Hollar (2003), Schadler and others (2004), and International Monetary Fund (2004b).

${ }^{10}$ Note that the negative growth of credit in the Czech and Slovak Republics in the early 2000s reflects, in part, the efforts to clean up the bad loans in the system.

11 These regimes include: currency board arrangements in Bosnia, Bulgaria, Estonia, and Lithuania; horizontal exchange rate bands in Hungary and Slovenia; fixed exchange rates in Latvia, Macedonia, and Ukraine; crawling bands in Belarus and Romania; and tightly managed floats in Croatia, Moldova, Russia, and Serbia.
} 
Figure 1. CEE Countries: Real Credit Growth over 2000-04 vs. Credit to GDP in 1999 (in percent)

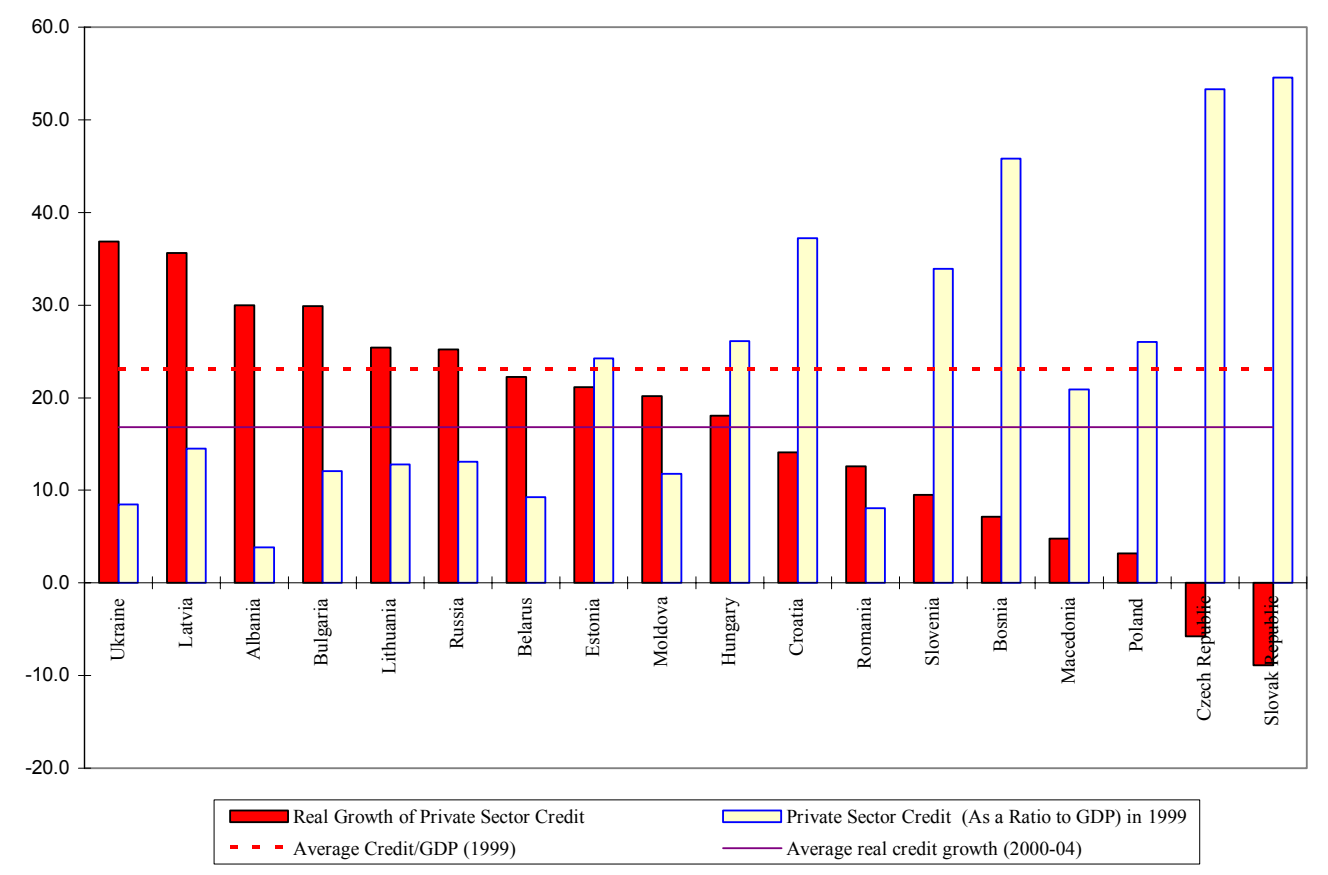

Figure 2. Real Private Sector Credit Growth and Financial Deepening in the CEE Countries (averages over 2000-2004)

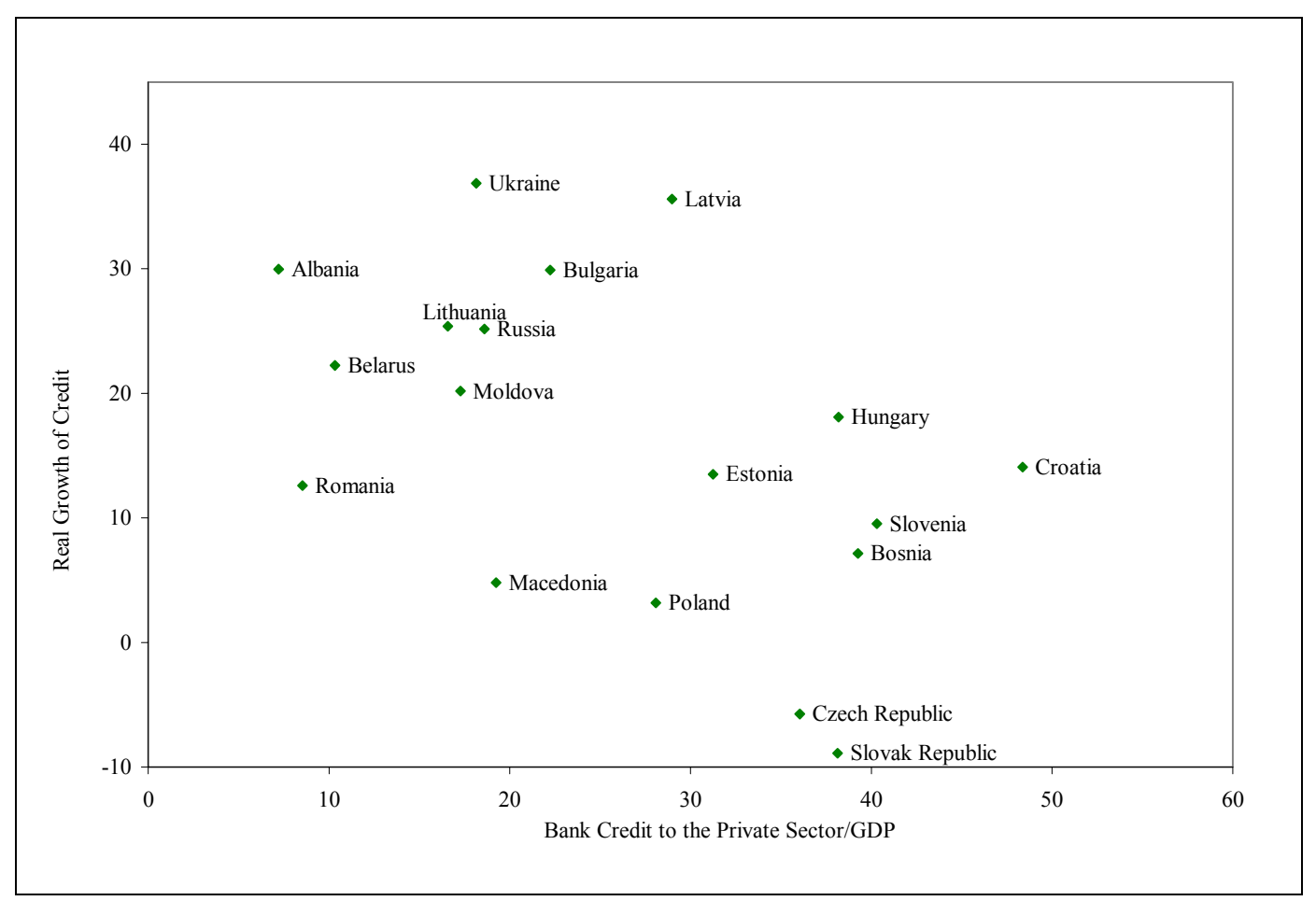


In most CEE countries, the banking sector is the most important channel of funds to support increased demand for credit, with capital and equity markets still small and relatively underdeveloped. The share of bank assets in total assets of the financial system (including also insurance companies, pension funds, securities firms, investment funds, and leasing companies) is in fact very high, generally exceeding 75 percent.

Privatization of the banking sector and increased participation by foreign banks has also contributed to rapid credit growth in a number of countries. Banks have now been largely privatized in most of the countries with the fastest growth of credit. The share of foreign ownership of banks has also been very high, with the share of assets ranging from around 6070 percent (Latvia, Romania, and Hungary) to about 80-90 percent (Bulgaria, Croatia, Estonia, and Lithuania). The expectation of high profits has been an important motive for foreign investors to move into the CEE banking market. While exposure to these countries in foreign banks' overall portfolio remains quite small, steady expansion of the foreign (mainly European) banking groups in the CEE region has had a positive impact on the profitability of the banks. In some of the CEE countries, foreign banks have engaged in aggressive lending to the private sector to raise their share in these profitable markets; this has resulted in downward pressure on lending rates and has helped stimulate credit demand. ${ }^{12}$

\section{B. Country Experiences with Lending Booms and Implications for CEE Countries}

This section compares the credit boom episodes in the sample of CEE countries (focus group) with those in a sample of benchmark countries to identify salient features and risks associated with credit booms. ${ }^{13}$ In doing so, it uses the methodology developed by Gourinchas and others (2001) to identify countries that have experienced lending booms. The deviation of the ratio of credit to GDP from a rolling country-specific trend is calculated, and lending booms are defined as episodes when the deviation from the trend exceeds a certain threshold value. ${ }^{14}$ The

${ }^{12}$ It is reported that about 70 percent of the CEE banking market is currently controlled by Western European banking groups (Breyer, 2004).

${ }^{13}$ The focus group includes: Albania, Belarus, Bosnia and Herzegovina, Bulgaria, Croatia, the Czech Republic, Estonia, Hungary, Latvia, Lithuania, Macedonia, Moldova, Poland, Romania, Russia, the Slovak Republic, Slovenia, and Ukraine. The benchmark group includes:

Argentina, Australia, Brazil, Canada, Chile, Dominican Republic, Ecuador, Egypt, Finland, Germany, Greece, Iceland, Indonesia, Ireland, Japan, Jordan, Korea, Lebanon, Luxembourg, Malaysia, Mexico, New Zealand, Norway, Paraguay, Philippines, Portugal, Singapore, Spain, Sweden, Thailand, Tunisia, Turkey, United Kingdom, United States, Uruguay, and Venezuela.

${ }^{14}$ The standard Hodrick-Prescott filter is sensitive to the beginning and end values of the series for which the trend needs to be determined. It is appropriate when the trend is to be determined in retrospect, but not as good in determining a boom when it is actually taking place. Gourinchas and others (2001) correct for this by using the recursive or rolling filter, which sets a trend for the first five years, then calculates a trend for the first 6 years, and another for the first 7 years etc. In this way, a continuing boom can be better identified. This methodology has its own shortcomings, which are discussed in more detail in Appendix I. 
analysis distinguishes between countries that experienced rapid credit growth and ended up with a banking crisis and those that did not. Crisis countries are those that have been identified by Caprio and Klingebiel (2003) as having experienced systemic banking crisis (see Appendix I for details).

This approach identifies four broad types of lending boom episodes in the sample, with some evidence of bunching up of episodes across time and regions:

- $\quad$ The lending boom episodes with no subsequent crises: These episodes include those of a number of industrial countries (Australia, Iceland, New Zealand, and United Kingdom), as well as developing countries (Egypt, Lebanon, and Indonesia) in which lending booms were driven largely by the financing needs of a large investment and consumption expansion as a result of structural reforms. These countries experienced a rapid and permanent financial deepening.

- Lending boom episodes with crises in the aftermath of the booms: These include the lending booms in Latin American countries and Turkey, where failed exchange rate based stabilization policies in the 1990s led to banking and currency crises, as well as in Lebanon and the Philippines. These countries suffered from a large disruption to the economy which was exacerbated by a subsequent credit crunch.

- $\quad$ Continuing lending boom episodes in the euro-convergence countries (this group of countries includes Greece, Ireland, Portugal, and Spain).

- $\quad$ Continuing lending boom episodes in certain CEE countries (Belarus, Bulgaria, Hungary, Latvia, Lithuania, Macedonia, and Ukraine).

The duration of boom episodes is shorter in the case of the crisis countries, while noncrisis countries are able to sustain high credit growth for a longer period. ${ }^{15}$ Lending booms are continuing in all of the seven CEE countries listed above as well as in the euro-convergence countries. So far, the average duration of the continuing boom episodes in the CEE countries is about 6 years, compared to 10.3 years in the euro-convergence countries (Table 3 ). The average level of the credit-to-GDP ratio at the beginning of the boom for the CEE countries (11.3 percent) is closer to the average level for the crisis countries (19.1 percent) than for the noncrisis countries (42.8 percent). However, it should be noted that the low initial credit-to-GDP ratios in CEE countries reflect the underdeveloped nature of domestic financial sector at the beginning of the transition. Many countries liberalized their financial sectors and

15 The typical boom episode is comprised of a build-up phase which starts when the credit-toGDP ratio rises above the limit threshold and ends a year before peak year, during which the episode reaches its largest deviation from the trend. The ending phase starts at the end of the peak year and ends when the ratio returns to the limit threshold. 
Table 3. Bank Credit to the Private Sector (BCPRS) during Credit Boom Episodes ${ }^{1,2,3}$

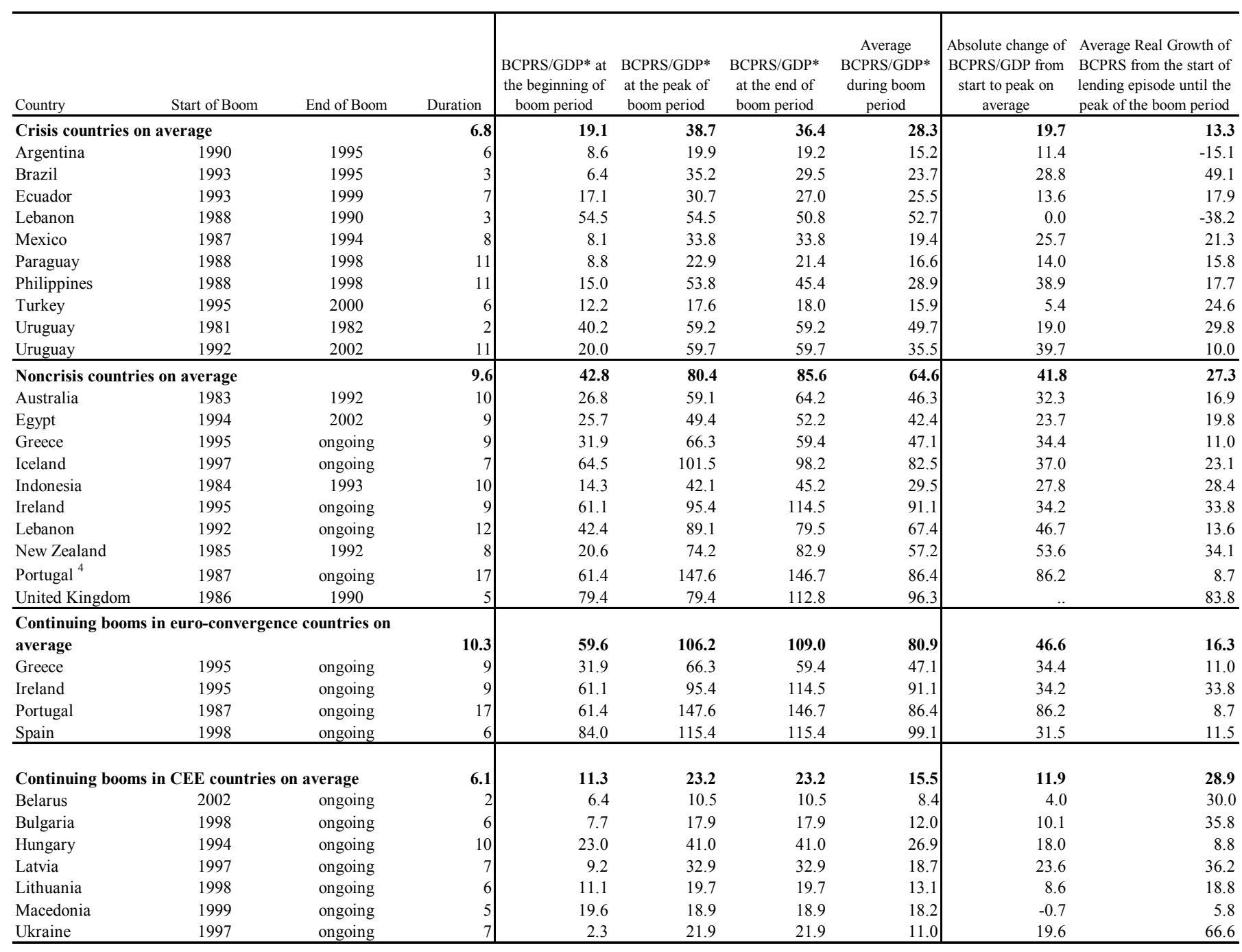

${ }^{1}$ The start and end of the boom periods are determined by using the methodology developed by Gourinchas, Valdes, and Landerretche (2001). In cases where the boom is ongoing, the end of the boom period is considered to be the end of the period under consideration.

${ }^{2}$ Note that countries can be categorized under more than one group.

${ }^{3}$ Credit booms in the Nordic countries during the latter part of the 1980s and early 1990s were not detected in this exercise; see further discussion on credit boom identification in Appendix I.

${ }^{4}$ The pace of the credit expansion accelerated in the 1990s. 
eliminated distortions at the beginning of the transition, while at the same time strengthening their supervision and regulation. The latter factor should be taken into account in comparing CEE countries to other countries that have witnessed a rapid credit expansion.

The following main developments in macroeconomic and financial sector indicators are observed during the credit boom episodes of the different subsamples (Figure 3):

- Lending booms are accompanied by a sharp deterioration in the trade balance and current account balance in the crisis countries. Similar trends are observed in CEE countries and euro-convergence countries where the current account deficit also widened sharply.

- Lending booms coincide with a decline in inflation in most of the countries. Inflation at the start of the lending boom is much higher in the crisis countries and declines sharply during the credit boom episode (credit booms coincided with stabilization programs in most of these countries). Inflation has been declining from already relatively low levels in most of the CEE countries.

- In the noncrisis countries growth accelerates prior to the start of the lending boom episode and the cyclical upturn continues until the peak. Although growth decelerates in the end phase, unlike in the case of the crisis countries, a sharp downturn is not experienced. In euro-convergence and CEE countries the credit boom period coincides with a period of relatively high economic growth.

- The fiscal position deteriorates during the build-up phase in the noncrisis countries while it improves in the euro-convergence countries. A sharp deterioration is observed in some of the crisis countries in the aftermath of the lending boom, reflecting the costs of bank restructuring. In most CEE countries the fiscal position has been improving during the course of the credit expansion period.

- $\quad$ The initial lending-deposit rate spreads are much wider in the crisis countries and CEE countries. However, while the spreads remained wide in the crisis countries, they have contracted in the CEE countries during the build-up phase.

- $\quad$ For most of the countries in the sample, loans are also being financed increasingly with liabilities other than deposits (loans are almost fifty percent higher than deposits). In particular for the CEE countries, loans are twice as large as deposits. In those countries, banks expand credit to the private sector by changing the composition of their assets and by increasing external borrowing (Figure 4).

Judging from these experiences, deterioration in external imbalances and high dependence on foreign funding suggest increased vulnerabilities in most of the CEE countries. The rapid expansion of bank credit seems to be associated with high current account deficits in most of the CEE countries. These deficits are partly caused by increasing import demand, which in turn may have been stimulated by credit growth. The low savings rates in most of the countries imply that they are highly dependent on the willingness of foreign investors to fund 
Figure 3. Macroeconomic Developments during Credit Boom Episodes (averages; in percent)
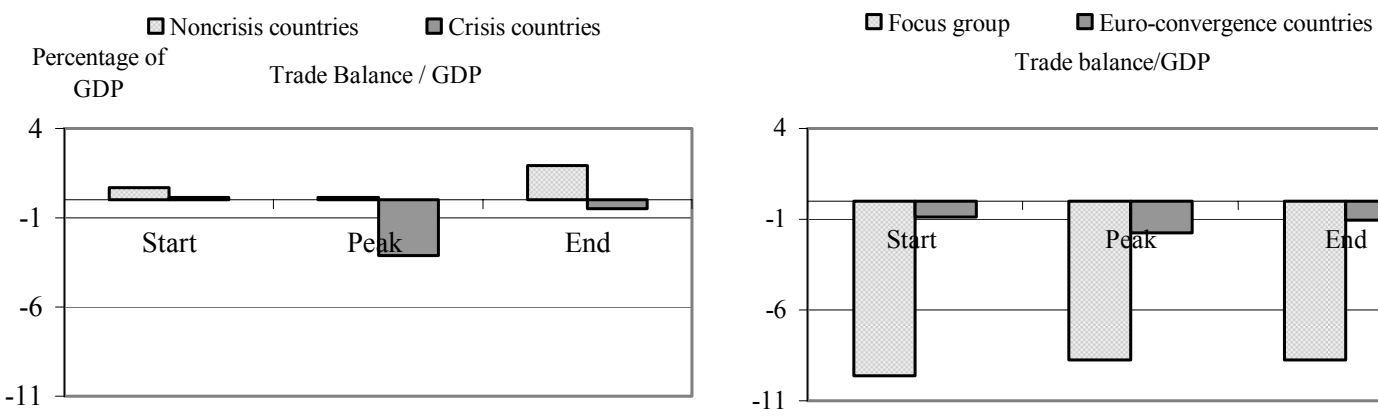

Current Account/GDP

Current Account/GDP
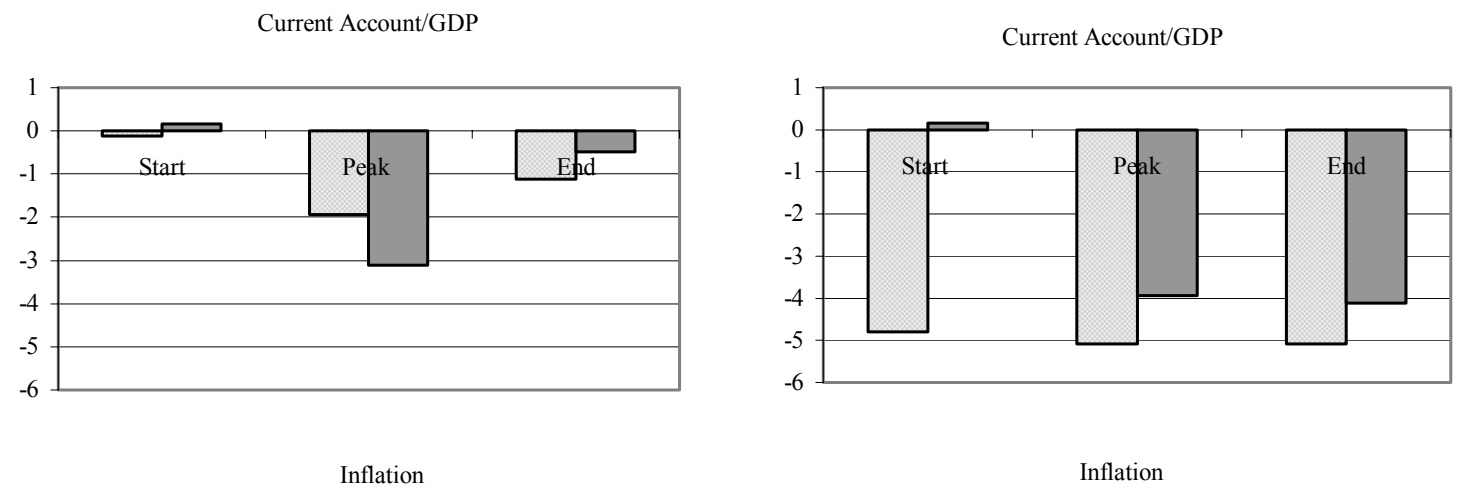

Inflation

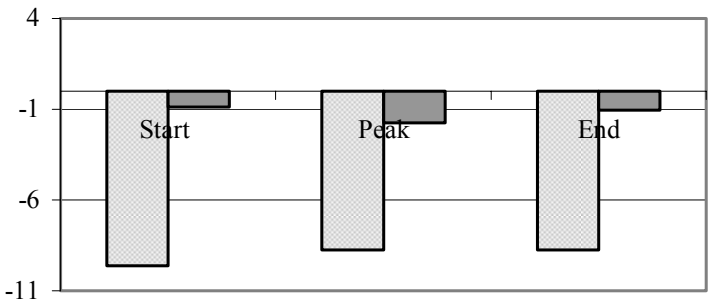
$-11$
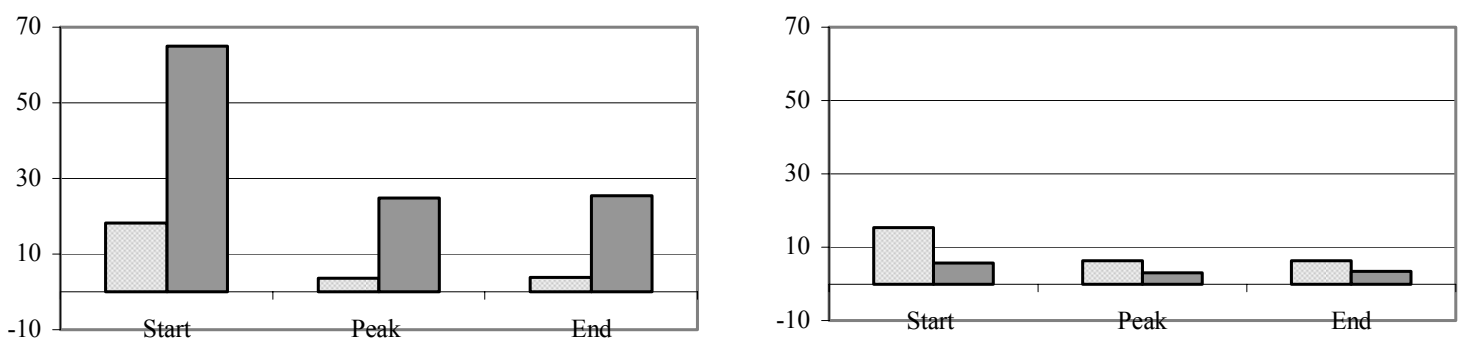

Real Growth of GDP

Real Growth of GDP
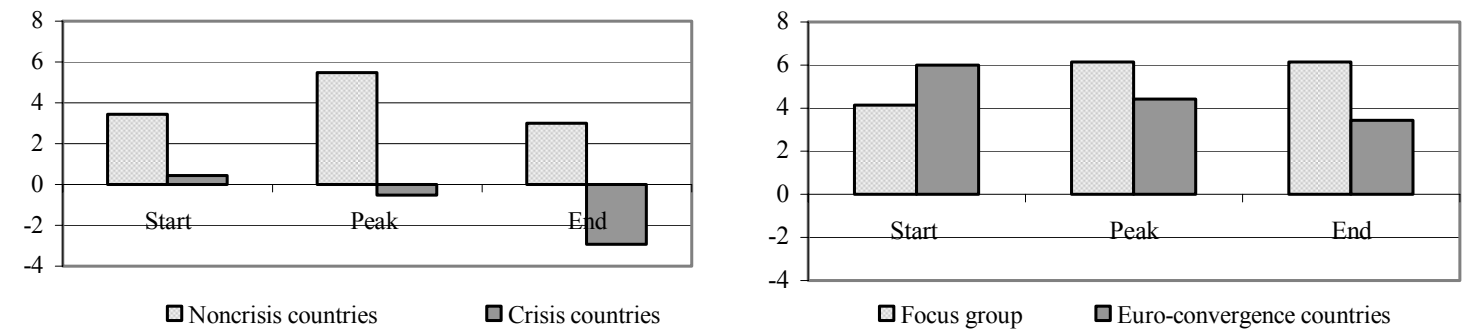

Source: International Financial Statistics, World Economic Outlook, IMF staff calculations

${ }^{1}$ Note that absolute change from start to peak represents average absolute change over the sample.

${ }^{2}$ For the focus group and euro-convergence countries, the end of the credit cycle marks the end of available data, i.e., all of the countries in these groups are experiencing continuing booms. 
Figure 3. Macroeconomic Developments during Credit Boom Episodes (cont.) (averages; in percent)
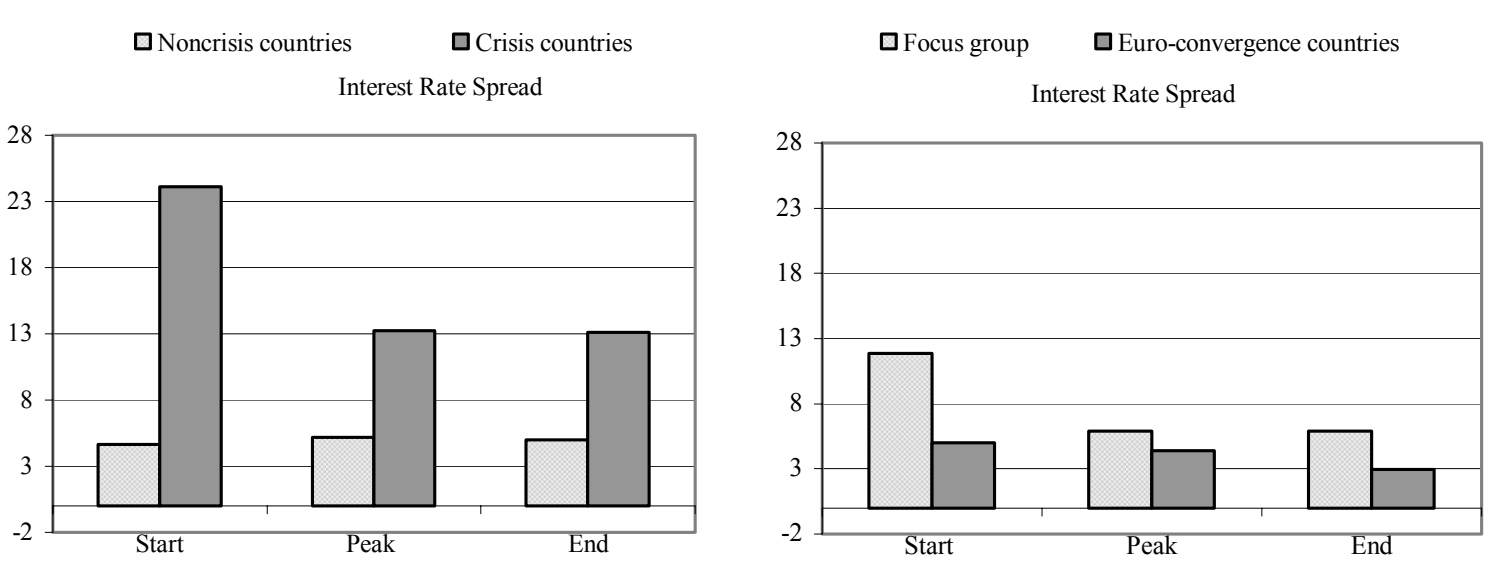

Loans/Deposits

Loans/Deposits
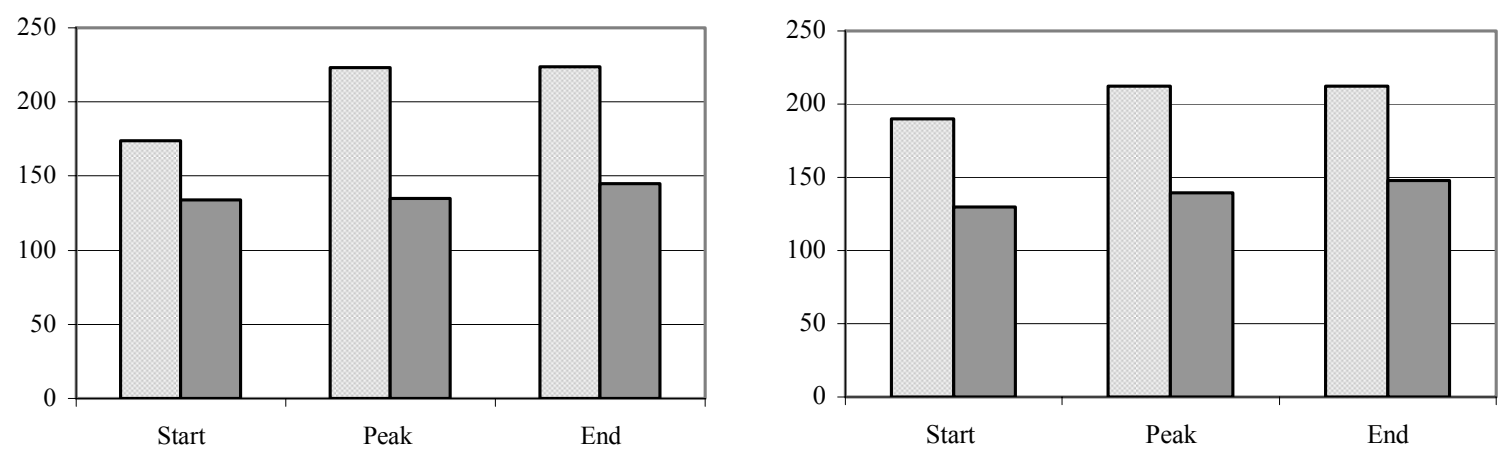

Fiscal Balance / GDP

Fiscal Balance/GDP
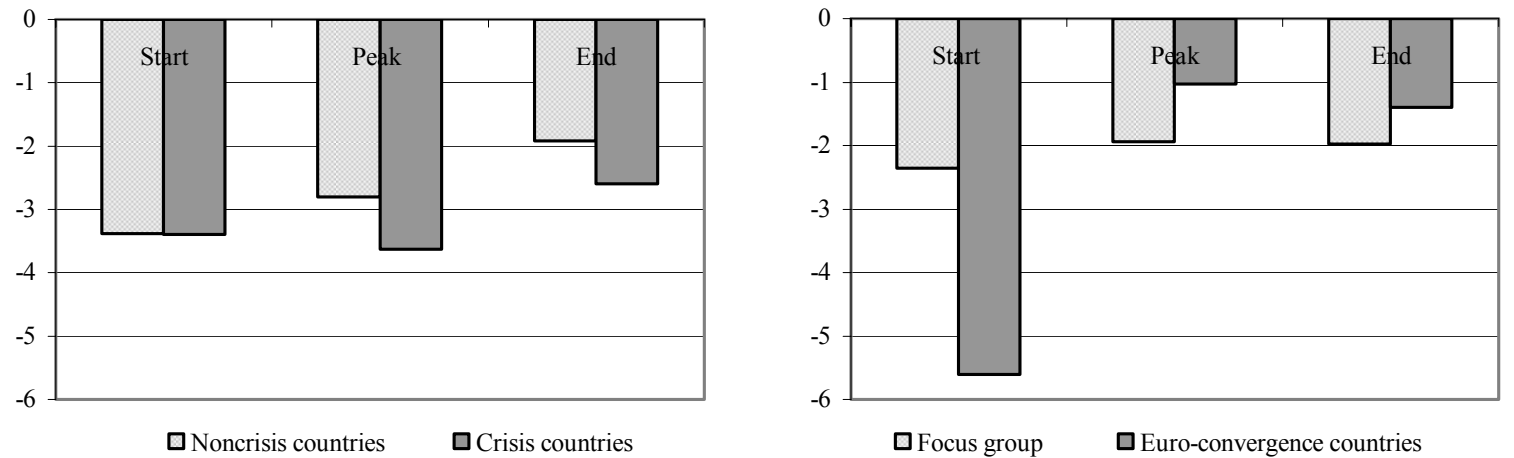

Source: International Financial Statistics, World Economic Outlook, IMF staff calculations

${ }^{1}$ Note that absolute change from start to peak represents average absolute change over the sample.

${ }^{2}$ For the focus group and euro-convergence countries, the end of the credit cycle marks the end of available data, i.e., all of the countries in these groups are experiencing continuing booms. 
Figure 3. Macroeconomic Developments during Credit Boom Episodes (cont.) (averages in percent)
$\square$ Noncrisis countries
$\square$ Crisis countries
$\square$ Focus group
$\square$ Euro-convergence countries
Private Consumption / GDP
Private Consumption/GPD
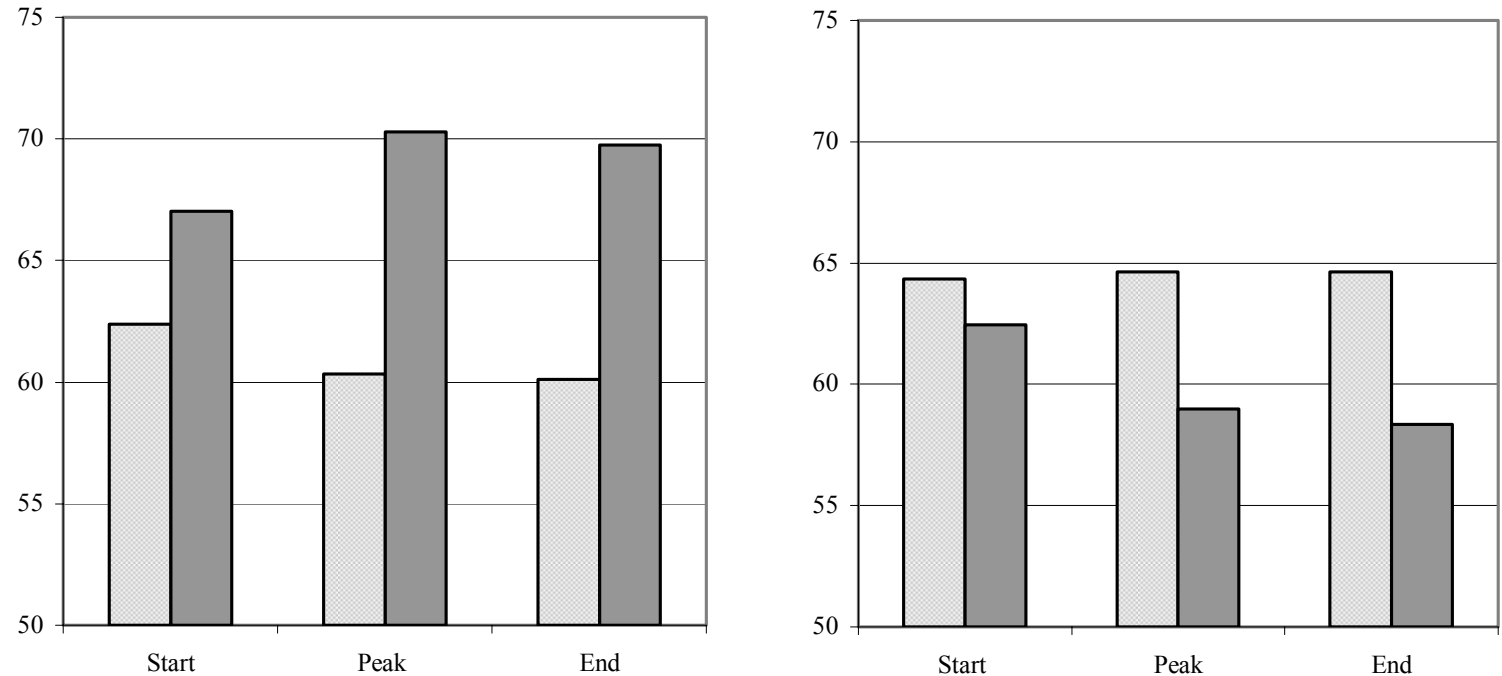

Net Direct Investment / GDP

Net Direct Investment / GDP
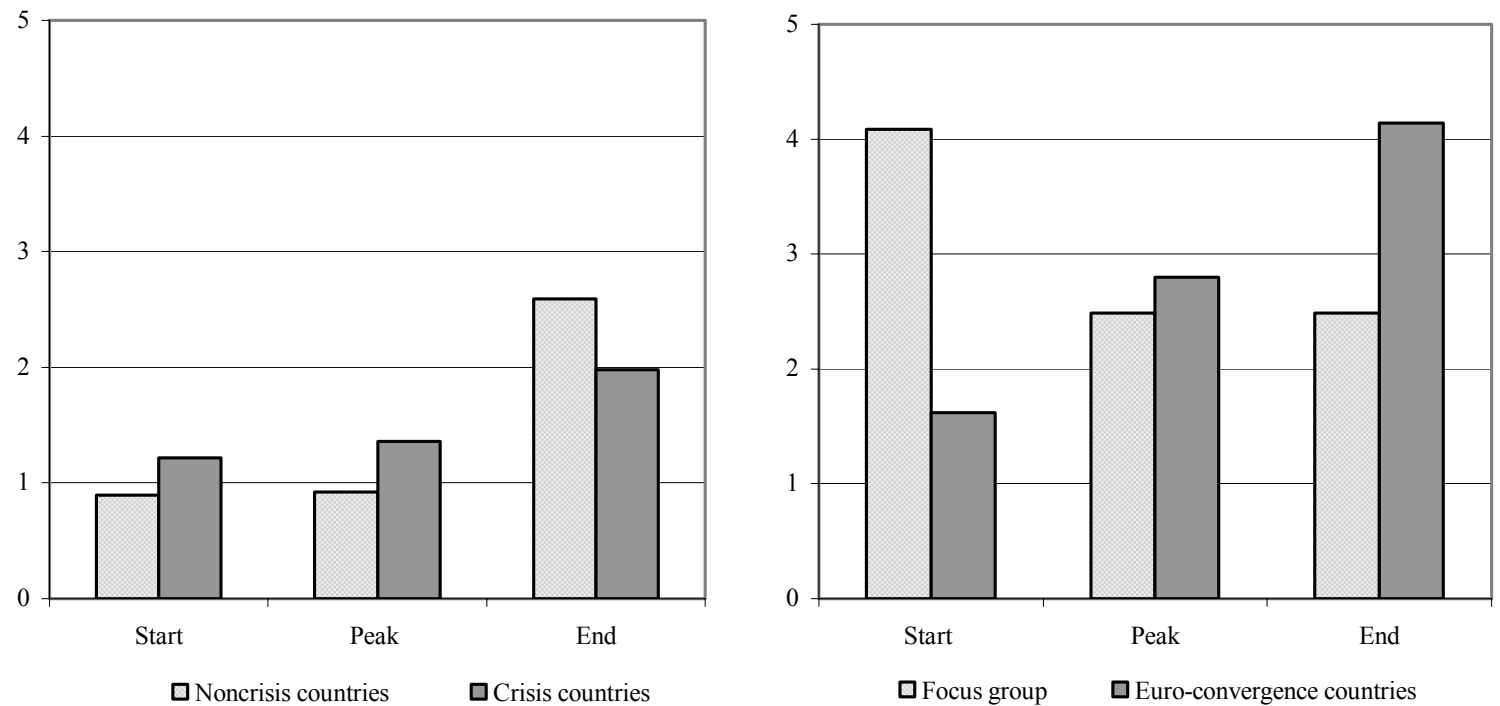

Source: International Financial Statistics, World Economic Outlook, IMF staff calculations

${ }^{1}$ Note that absolute change from start to peak represents average absolute change over the sample.

${ }^{2}$ For the focus group and euro-convergence countries, the end of the credit cycle marks the end of available data, i.e., all of the countries in these groups are experiencing continuing booms. 
Figure 4. CEE Countries: Funding of the Credit Growth (in national currencies)
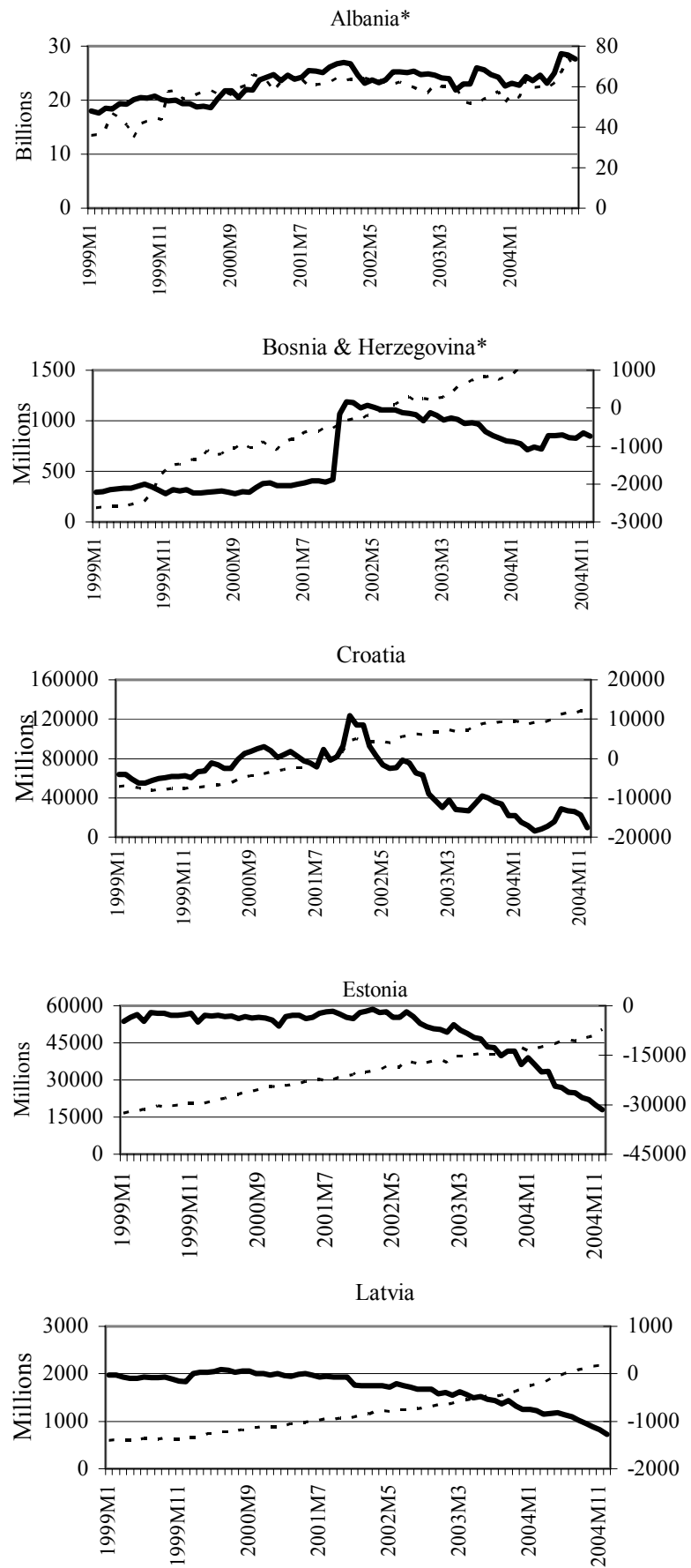

Source: International Financial Statistics

*only demand deposits
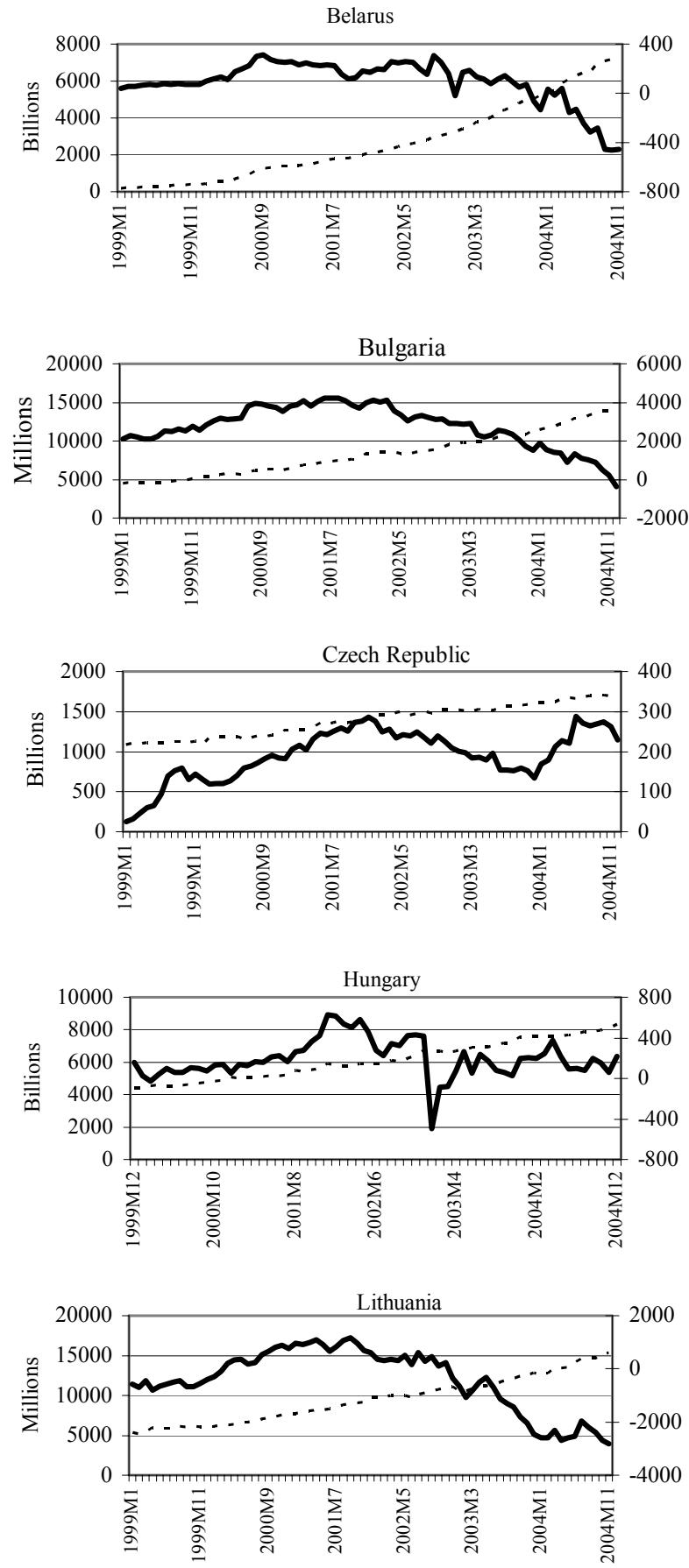
Figure 4. CEE Countries: Funding of the Credit Growth (cont.) (in national currencies)
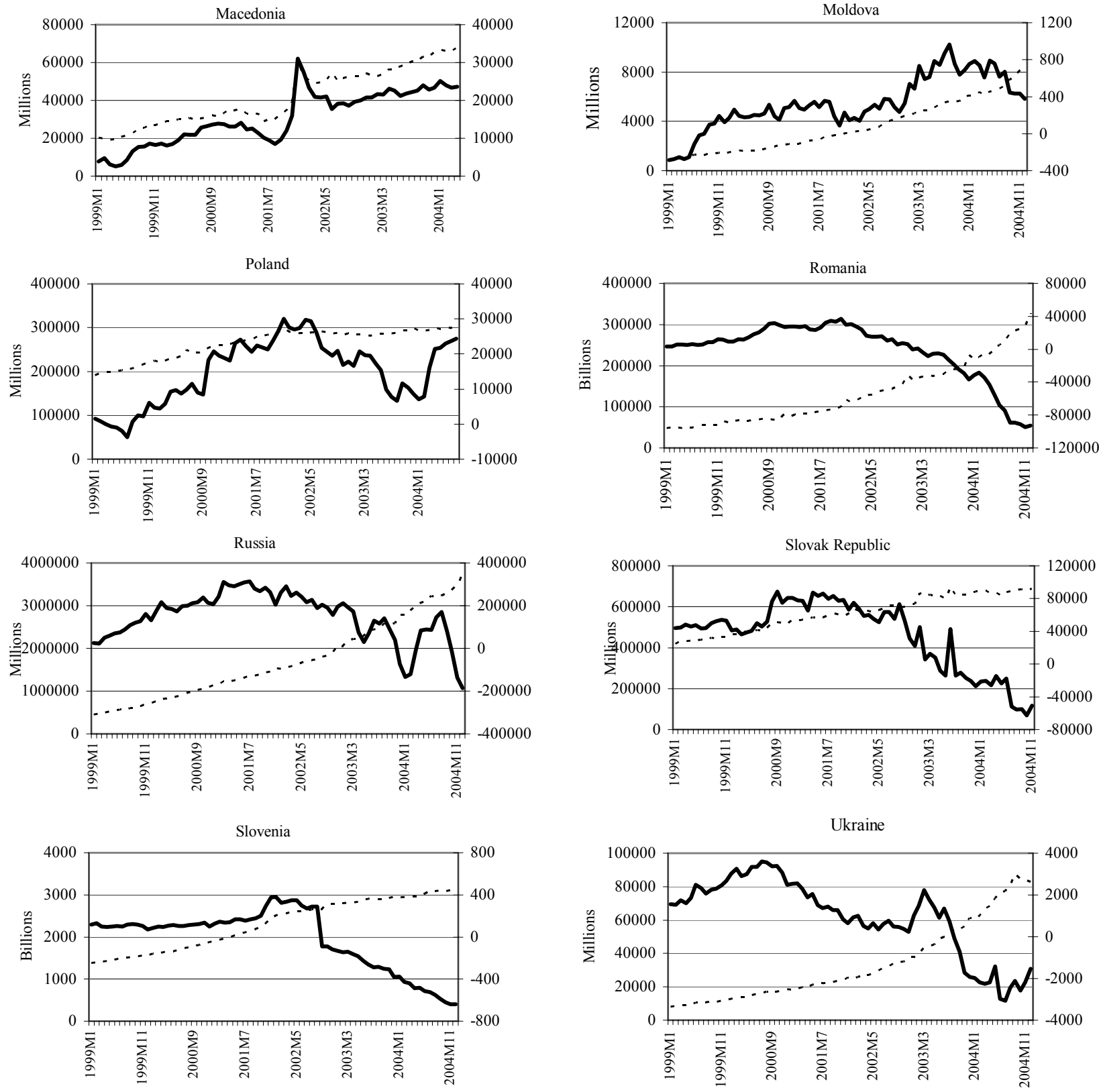

Source: International Financial Statistics 
these deficits (Figure 3). An additional source of vulnerability is that the strength of the credit growth has been sustained by an increase in net foreign liabilities of the banks in many of the countries (Figure 4). Banks have been borrowing funds from abroad (including foreign banks from their parents) and/or have been drawing down their foreign assets.

It is not clear how well the comparatively new and untested credit risk systems of many banks in CEE markets are able to cope with a (potential) lending boom. In most CEE countries, the prudential indicators do not seem to indicate a sizable increase in financial vulnerabilities in the banking system: banks are highly capitalized and profitable, either with relatively low or declining nonperforming loans (Table 4 and Appendix II). However, nonperforming loans are usually a lagging indicator of banking system problems, and there have been some indications of a decline in capital adequacy and some increase in credit risks in many of the countries in the group. Potential risks from greater lending to the household/consumer sector are increasing, and in some cases, rapid credit growth started to put some strain on bank supervisors' and banks' capacity to assess risks. In many CEE countries, banks' potential exposure to indirect foreign exchange risks may have increased: foreigncurrency-denominated lending represents a substantial proportion of total loans in many CEE countries, while information on customers' foreign currency positions and the extent of their hedging has remained limited. There are also indications of potential liquidity risks in some of the countries, as suggested by the maturity of loans.

A decline in margins may also create strains on the banking system. In the medium term, a lower country risk premium (due to convergence) and increased competition should lead to a convergence of margins towards the EU average (a decline in margins has already been observed in some countries for corporate lending but not for consumer and mortgage lending). Competition should increase as countries become EU member states, because entry barriers will decline under the European single passport regime under which any bank registered in an EU member state can establish branches in another EU country without a local banking license (Breyer, 2004). Potential EU accession has led to increased competition among banks (e.g., in Bulgaria and Romania; Duenwald, Gueorguiev and Schaechter, 2005) as these banks have a strong incentive to increase market shares ahead of full membership. The compression of margins in EU accession countries may come to a point where the margins may become too narrow to compensate for the risks in lending.

\section{Policy Responses to Rapid CRedit Growth in the CEE Countries}

Experiences of many countries that underwent financial crises suggest that misperceptions of the evolution of risks over time and inadequate or inappropriate policy responses can have costly consequences. As Borio, Furfine, and Lowe (2001) note, there may be a case for a public policy response if it is likely that rapid credit growth is due to inappropriate responses by financial system participants to changes in risk over time. Policies designed to limit vulnerability of the real and financial sector may hence be necessary to prevent macroeconomic and financial instabilities. While there is a need to avoid "crying wolf" when observed developments may be a simple result of 
catching-up, it would be unduly optimistic to assume that rapid credit growth to a new, and much higher, "equilibrium" level of credit would automatically be without any risks or need for action. ${ }^{16}$

Table 4. Selected Financial Indicators for the CEE Countries with the Fastest Growth of Credit (As of 2003, in percent)

\begin{tabular}{|c|c|c|c|c|c|c|c|c|c|c|}
\hline Country & $\begin{array}{c}\text { Capital } \\
\text { ratio } \\
\text { (CAR) } \\
\end{array}$ & $\begin{array}{c}\text { Absolute } \\
\text { change in } \\
\text { CAR since } \\
1999 \\
\end{array}$ & $\begin{array}{l}\text { NPL/ } \\
\text { total } \\
\text { loans } \\
\end{array}$ & $\begin{array}{c}\text { Absolute } \\
\text { change in } \\
\text { NPLs since } \\
1999 \\
\end{array}$ & $\begin{array}{c}\text { Foreign } \\
\text { bank } \\
\text { share } \\
\end{array}$ & $\begin{array}{l}\text { Share of } \\
\text { loans to } \\
\text { industry }\end{array}$ & $\begin{array}{l}\text { Share of } \\
\text { loans to } \\
\text { household } \\
\text { sector } \\
\end{array}$ & $\begin{array}{l}\text { Share } \\
\text { of FX } \\
\text { loans } \\
\end{array}$ & $\begin{array}{l}\text { Maturity } \\
\text { of loans }{ }^{1}\end{array}$ & $\begin{array}{l}\text { Loan to } \\
\text { deposits }\end{array}$ \\
\hline Belarus & 26.0 & 0.5 & 4.8 & -6.0 & 21 & 38 & 20 & 50 & 28 & 141 \\
\hline Bulgaria & 22.2 & -19.1 & 7.3 & -4.3 & 80 & 70 & 28 & 43 & 70 & 81 \\
\hline Croatia & 15.7 & -4.9 & 5.1 & -5.2 & 90 & 40 & 49 & 75 & .. & 111 \\
\hline Estonia & 14.5 & -1.5 & 0.4 & -1.4 & 90 & 34 & 28 & 60 &.. & 104 \\
\hline Hungary & 13.0 & -1.2 & 2.2 & -2.0 & .. & 46 &.. & 37 &.. & 443 \\
\hline Latvia & 13.0 & -3.3 & 1.9 & -4.3 & 54 &.. & .. & 50 & 80 & 153 \\
\hline Lithuania & 17.0 & -0.6 & 9.0 & -2.6 & 89 & 69 & 21 & 53 & 73 & 114 \\
\hline Moldova & 31.8 & -14.2 & 6.2 & -23.1 & 38 & 46 & 8 & 43 &.. & 105 \\
\hline Romania $^{2}$ & 19.9 & -3.8 & 8.3 & +3.1 & 58 &.$\cdot$ & 22 & 75 & 50 & 84 \\
\hline Slovenia & 11.5 & -2.5 & 6.5 & +1.3 & 35 & 75 & 27 & 25 & 61 & 92 \\
\hline Ukraine $^{3}$ & 15.1 & -4.5 & 28.3 & -7.5 & 13 & 30 & 13 & 38 & 44 & 91 \\
\hline
\end{tabular}

Sources: International Financial Statistics, World Economic Outlook, various IMF country reports.

Explanation: $\mathrm{NPL}=$ non-performing loans; $\mathrm{FX}=$ foreign exchange.

${ }^{1}$ The share of long-term loans in total loans.

${ }^{2}$ The change in NPLs may partly reflect a tightening of the definition of NPLs in 2003.

${ }^{3}$ Under a relatively tight definition of NPLs, a large share of NPLs is serviced timely.

In considering the appropriate policy response, it would be useful to start from a menu of possible measures and consider their pros and cons, negative consequences and limitations in dealing with the problem, and the circumstances under which they could be used. These options include:

macroeconomic policy measures (monetary, fiscal, and exchange rate); prudential, supervisory, and monitoring measures; measures fostering the development of financial markets and institutions; administrative/more direct measures; and measures aimed at an improved understanding of risk (see Figure 5 for a list of measures under each category and Appendix III for more detailed assessments of these measures). The following subsections discuss possible approaches to address rapid credit growth in the CEE countries.

${ }^{16}$ Computing the "equilibrium" level of credit in these economies is not a trivial exercise, given the structural changes that affected these economies and the short time span of economic and financial sector data. Estimation of the equilibrium level for Central and Eastern Europe and Balkan countries in Cottarrelli, Dell'Ariccia, and Vladkova-Hollar (2003) suggests that in most of these countries the current credit-to-GDP ratios are still relatively low compared to the estimated equilibrium levels. Also, Schadler and others (2004) include estimates of equilibrium credit-to-GDP levels and dynamic paths toward them. 


\section{A. Measures Taken in Response to Rapid Credit Expansion}

The authorities in many of the CEE countries have taken measures while facing the dilemma of whether or not to interfere with ongoing rapid credit expansion. In general, a combination of the measures listed in Figure 5 was used, rather than a single instrument. ${ }^{17}$ Monetary measures that have been widely used took the form of interest rate tightening (and in some cases, e.g., in Poland, reduction in domestic interest rates to narrow interest rate differentials), changes in the parameters of reserve requirements, introduction of liquidity requirements, and greater exchange rate flexibility. Fiscal policy has been tightened in some countries or fiscal incentives in the form of mortgage interest deductibility and mortgage subsidies have been reduced (Table 5). Many have taken prudential and supervisory measures in the form of tightening the existing regulations, or close monitoring and assessment of loan underwriting or granting procedures, and/or surveys of banks' direct or indirect foreign exchange exposures. A few have established a credit registry system, credit bureaus, and wider information bases to improve market discipline. In a few countries, administrative measures have been taken through direct credit controls or marginal reserve requirements on foreign borrowing. Moral suasion has also been used on a few occasions. The measures have been, in general, motivated by concerns about emerging signs of external problems as well as the stability of financial systems.

The effectiveness of these policy responses has varied. ${ }^{18}$ In a few of the cases, the measures seem to have been effective in reducing credit growth or certain targeted types of lending (e.g., Bosnia, Croatia, and Poland). As discussed in Section III, in many of the countries concerned, credit growth remains strong, with few signs of abating, and in a few others, despite some indications of a slowdown, the rate of growth remains high. Persistent strength of foreign-currency-denominated lending in several countries has continued to keep banks vulnerable to potential (direct or indirect) foreign exchange rate risk.

Efforts to slow down credit have in general been frustrated by a number of factors. The measures had little impact on banks' sources of funds for lending, given their ability to obtain funding through rapid deposit growth and borrowing from abroad (in particular through parent banks). The process was further supported by high profitability of domestic lending, often in the wake of EU accession.

${ }^{17}$ A combination of instruments has also been used by a number of other European countries that entered the EU earlier and have experienced rapid credit growth during the period of their accession to the euro area (see Appendix IV for details): Greece, for example, imposed direct credit controls, Portugal tightened the prudential and supervisory framework accompanied by a rise in interest rates, while Spain introduced dynamic provisioning. Outside the EU, Iceland has used a combination of moral suasion and monetary measures, including a liquid asset requirement.

${ }^{18}$ Note, however, that many of the CEE countries are still in the midst of a period of rapid credit growth, and some of the measures taken may not yet have demonstrated their full impact. Any assessment of the effectiveness of measures is, therefore, necessarily preliminary. There is also the problem of the counterfactual, that is, the difficulty of determining what could have happened in the absence of these measures. 
- 24 -

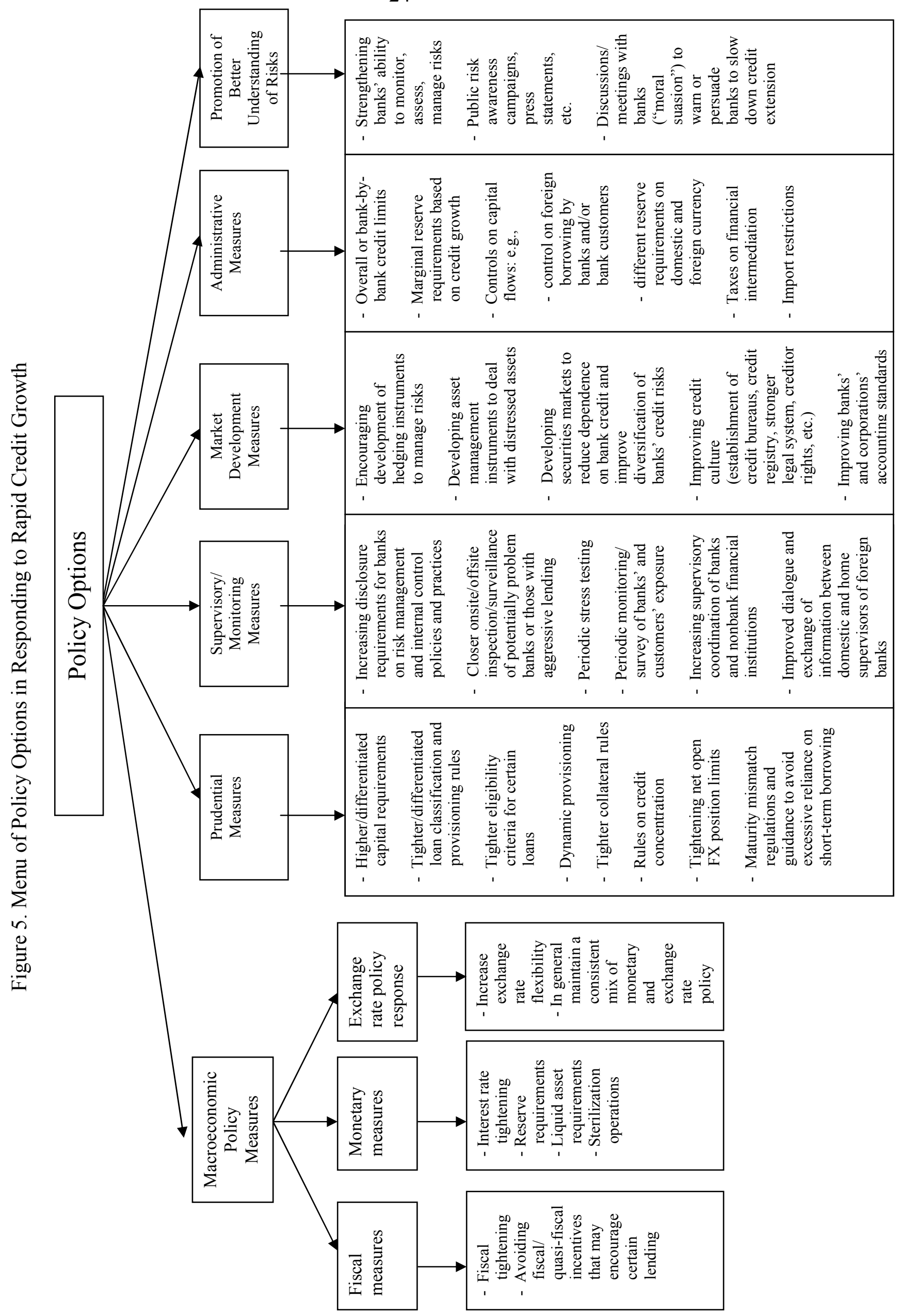


Table 5. Policy Responses to Rapid Credit Growth in Selected CEE Countries

\begin{tabular}{|c|c|c|}
\hline Country & Measures with potential impact on credit growth & Impact to date \\
\hline $\begin{array}{l}\text { Bosnia } \\
(2003)\end{array}$ & $\begin{array}{ll} & \text { Monetary measures (tightening-reserve requirements) } \\
\text { - } & \text { Prudential measures (tightening) }\end{array}$ & $\begin{array}{l}\text { Seems to be effective in easing the credit } \\
\text { growth. }\end{array}$ \\
\hline $\begin{array}{l}\text { Bulgaria } \\
\text { (mid-2003 } \\
- \text { Feb-2005) }\end{array}$ & $\begin{array}{ll}\text { - } & \text { Monetary measures (tightening-reserve requirements) } \\
\text { - } & \text { Fiscal measures (tightening) } \\
\text { - } & \text { Market development measures (credit registry, wider information base) } \\
\text { - } & \text { Administrative/other measures (credit controls - marginal reserve requirement } \\
& \text { for banks exceeding a certain level of credit growth) } \\
\text { - } & \text { Other measures (moral suasion) }\end{array}$ & $\begin{array}{l}\text { Domestic credit growth remains strong } \\
\text { (though with some stabilization in the } \\
\text { growth rate during January-February } \\
\text { 2005). Banks remain vulnerable to } \\
\text { indirect FX risk. Effect of the recent } \\
\text { credit controls remains to be seen. }\end{array}$ \\
\hline $\begin{array}{l}\text { Croatia } \\
(2000-05)\end{array}$ & 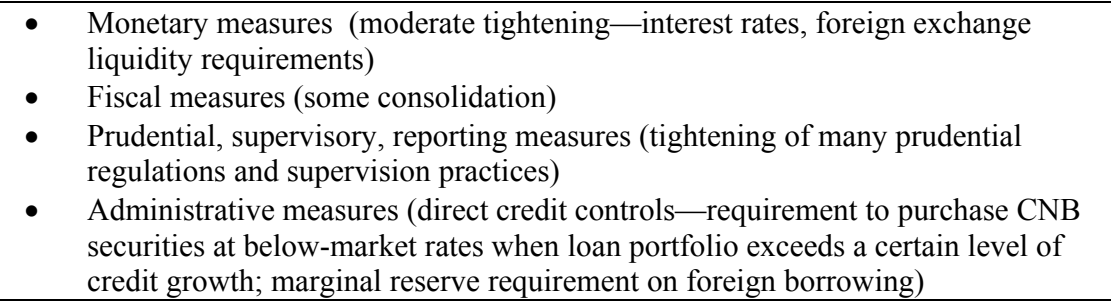 & $\begin{array}{l}\text { Credit growth slowed significantly since } \\
\text { late 2003, but impact on aggregate } \\
\text { demand limited: credit controls } \\
\text { circumvented via switch to nonbank and } \\
\text { foreign borrowing, with potential } \\
\text { adverse impact on soundness of the } \\
\text { financial system. Banks remain } \\
\text { vulnerable to indirect FX risk. }\end{array}$ \\
\hline $\begin{array}{l}\text { Estonia } \\
\text { (2004) }\end{array}$ & $\begin{array}{ll} & \text { Fiscal measures (reducing existing distortions) } \\
\text { - } & \text { Supervisory measures (close monitoring of developments) } \\
\text { - } & \text { Other measures (moral suasion) } \\
\end{array}$ & $\begin{array}{l}\text { Domestic credit growth has remained } \\
\text { strong; continued exposure to potential } \\
\text { FX risk. }\end{array}$ \\
\hline $\begin{array}{l}\text { Latvia } \\
(2004)\end{array}$ & - $\quad$ Monetary measures (tightening — interest rates, reserve requirements) & $\begin{array}{l}\text { Credit growth remained strong. Banks } \\
\text { remain exposed to indirect FX risk. }\end{array}$ \\
\hline $\begin{array}{l}\text { Moldova } \\
(2004)\end{array}$ & $\begin{array}{l}\text { - } \quad \text { Monetary measures (reserve requirement rules) } \\
\text { Prudential/supervisory measures (the central bank required banks to have } \\
\text { separate risk management units to identify and reduce specific risk exposures; } \\
\text { assessment of credit risk is made on a borrower-by-borrower basis, and banks } \\
\text { share information on problem borrowers on an informal basis, in the absence of a } \\
\text { credit registry) }\end{array}$ & $\begin{array}{l}\text { Credit growth slowed somewhat but still } \\
\text { remained strong. Banks remain } \\
\text { vulnerable to indirect FX risk. }\end{array}$ \\
\hline $\begin{array}{l}\text { Poland } \\
(2001)\end{array}$ & $\begin{array}{l}\text { - Monetary measures (narrowing domestic interest rate differentials, increasing } \\
\text { flexibility of the exchange rate) } \\
\text { Prudential, supervisory, reporting measures (adjusting capital requirements for } \\
\text { FX risk, periodic surveys/close monitoring of banks' FX exposure, risk } \\
\text { management, and internal controls) } \\
\text { - Other measures (moral suasion) }\end{array}$ & $\begin{array}{l}\text { Rapid growth of FX-denominated loans } \\
\text { slowed significantly and households } \\
\text { became more careful about unhedged } \\
\text { borrowing. Total credit growth subdued } \\
\text { since } 2000 .\end{array}$ \\
\hline $\begin{array}{l}\text { Romania } \\
(2003-05)\end{array}$ & $\begin{array}{l}\text { - } \quad \text { Monetary and fiscal measures (tightening) } \\
\text { Prudential and supervisory measures (tightening-especially tightening of loan } \\
\text { classification, eligibility criteria, reserve requirement on banks' FX denominated } \\
\text { liabilities) } \\
\text { - } \quad \text { Market development measures (credit bureau, widening information base) } \\
\text { - }\end{array}$ & $\begin{array}{l}\text { Credit growth slowed somewhat from } \\
\text { August } 2003 \text { to April } 2004 \text {. Growth in } \\
\text { lei credit nearly came to a halt, partially } \\
\text { offset by a continuing expansion of } \\
\text { FX-denominated credit. }\end{array}$ \\
\hline $\begin{array}{l}\text { Serbia } \\
(2004-05)\end{array}$ & $\begin{array}{l}\text { - } \quad \text { Monetary measures (tightening - reserve requirements) } \\
\text { Prudential and supervisory measures (tightening): tightening conditions for } \\
\text { consumer loans, broadening the reservable base to include banks' foreign } \\
\text { borrowing, increase in capital adequacy ratio; plan to introduce a regulation on } \\
\text { monitoring/ managing credit risk from borrowers' exposure to FX risk }\end{array}$ & $\begin{array}{l}\text { Monetary measures did not have a } \\
\text { tangible impact, under high euroization. } \\
\text { Given the fairly recent implementation } \\
\text { of the prudential measures, effectiveness } \\
\text { viewed only on a preliminary basis. } \\
\text { Consumer lending and credit to non- } \\
\text { government slowed down after the } \\
\text { tightening measures. Banks vulnerable } \\
\text { to indirect FX risk. }\end{array}$ \\
\hline $\begin{array}{l}\text { Ukraine } \\
\text { (2004) }\end{array}$ & $\begin{array}{l}\text { - } \quad \text { Monetary measures (limited tightening) } \\
\text { Prudential and supervisory measures (tightening-rules on capital adequacy, } \\
\text { quality of bank capital, loan classification, provisioning for FX-denominated } \\
\text { loans, related party lending, risk management etc.) }\end{array}$ & $\begin{array}{l}\text { The rate of growth of bank credit slowed } \\
\text { down significantly, though still at a } \\
\text { relatively high rate. Banks remain } \\
\text { vulnerable to indirect FX risk. }\end{array}$ \\
\hline
\end{tabular}

Source: See Appendix IV for details on these measures, their timing, and the impact to date; FX = foreign exchange. 
Some measures were rendered ineffective by the circumvention of regulations by borrowers (through the ability to borrow directly from abroad or from less supervised/regulated nonbank financial institutions) and by banks (e.g., through window-dressing activities). Integration of domestic markets in the euro environment brought a general easing of monetary conditions that likely stimulated credit demand. The high degree of euroization of the economies, a lack of effective instruments of monetary control, and weaknesses in the monetary transmission mechanism have limited the capacity to effectively use monetary measures.

\section{B. Further Policy Options}

The key question is what further options are left for the CEE countries in dealing with rapid credit growth? In contemplating the appropriate policy response, policymakers need to focus on the nature of the associated risks, in particular of macroeconomic and financial risks. As discussed in Section II, these risks are interrelated: particularly when the growth of credit is very rapid, it is difficult to disentangle macro risks from prudential ones, with one possibly leading to, or reinforcing, the other. The policymakers therefore need to focus on both the macroeconomic and the financial implications of the credit growth. This in turn calls for a package of measures that contains both macroeconomic and prudential tools. Adding to the need for a broader policy package is the fact that macroeconomic and prudential measures affect each other. Prudential measures to preserve credit quality may limit certain types of lending and hence have negative implications for macroeconomic and financial sector health; similarly, an appropriate macroeconomic policy mix may limit incentives for excessive borrowing and lending in foreign exchange, hence limiting the scope for deterioration in credit quality. An appropriate combination of macro and prudential measures could then be used to achieve a desired effect on quality as well as quantity of bank loans.

The choice of particular measures will be affected by an assessment of the nature of risks implied by the nature of the credit growth. As discussed earlier, the starting point for such an assessment should be an analysis of the credit growth on the basis of detailed underlying data, including the speed of the growth, breakdown of aggregate credit in terms of the borrower (households, corporate sector, exporters, etc.), the sectoral concentration and allocation of the loan (mortgages, durable consumer goods, investments), the currency composition of loans (foreign exchange versus local currency), the maturity of the loans, availability of adequate collateral, and the funding sources of the credit.

The appropriate policy response will also be affected by the prevailing macroeconomic policy framework. In this context, managing rapid credit growth has been a significant challenge for some of the CEE countries, since the set of available measures is limited due to the specific characteristics of these countries:

- Tightening monetary conditions in response to credit growth may help dampen overheating pressures by impacting aggregate demand, helping to reduce demand for bank loans, or reducing banks' liquidity base that helps finance the credit growth. However, in many of the CEE countries, the ability to use monetary policy has been constrained 
by the underlying monetary policy regime. Most have pegged or tightly managed exchange rate regimes that limit the use of market-based monetary tools in coping with credit growth. In several, effective monetary instruments are not fully developed, constraining the ability to manage liquidity in the system. The relatively high level of euroization (and other structural factors) weakens monetary transmission mechanisms making it difficult to influence lending and retail rates through changes in policy rates. An open capital account limits the ability to use monetary policy effectively in a number of countries, especially with pegged exchange rate regimes, because interest rate tightening may attract capital inflows that can further boost money and credit. Monetary policy can be used effectively if efforts are put into developing market-based monetary instruments and eliminating obstacles to monetary transmission.

- Where there is a significant increase in foreign-currency-denominated lending and a tendency to borrow from abroad, increasing the flexibility of the exchange rate and maintaining a consistent monetary-exchange rate policy mix would help limit direct and indirect foreign currency exposures by reducing perceptions of low exchange rate risk. ${ }^{19}$ For example, increasing the flexibility of the exchange rate and allowing domestic interest rate differentials to narrow in combination with supervisory tools helped reduce foreign currency denominated bank lending in Poland during the early 2000s. Where the monetary framework is characterized by formal peg commitments (e.g., in a currency board or under ERM II in a run-up to joining the euro area), room for such policy maneuver is limited, however; the first best policy in this case would be to keep domestic interest rates consistent with the exchange rate commitment to limit incentives for excessive lending and borrowing and to address any structural factors that may be contributing to high interest margins (e.g., high risk premium, high transaction or operational costs, tax distortions, etc.).

- $\quad$ Tightening fiscal policy further and maintaining a prudent stance would help counter the expansionary pressures that may be brought by credit expansion in some of the CEE countries. In a number of others, however, where the fiscal position is already tight, the authorities may find limited room to resort to fiscal measures. Where there are fiscal incentives that may be encouraging certain types of borrowing or lending (such as interest deductibility for mortgage loans, explicit subsidies or government guarantees for housing loans, interest rate subsidies, etc.), addressing these distortions would be an appropriate policy response.

${ }^{19}$ Highly predictable exchange rates, combined with large domestic interest differentials that are inconsistent with the exchange rate regime, may create perceptions of low exchange rate risks and encourage foreign borrowing. On-lending in domestic currency creates exposure to direct foreign exchange risks, while on-lending in foreign currency to unhedged borrowers or those with no foreign exchange income raises exposure to indirect foreign exchange risks. 
The key question is whether prudential and supervisory measures could substitute for monetary and fiscal policies in coping with rapid credit growth when the latter policies are not a viable option. When rapid credit growth (e.g., with excessive concentration in certain types of loans such as mortgages or in foreign-currency-denominated lending to unhedged borrowers) is generated by inconsistencies or distortions in macroeconomic/structural policies, the first best policy response should be to eliminate those distortions or inconsistencies. The use of prudential and supervisory measures should be genuinely justified on prudential grounds so as not to inflict undue burden on the supervisory authorities and banks. Given the inter-linkages between macroeconomic and financial concerns discussed above, prudential measures can be used to support macro policies to limit a deterioration of the quality of banks' assets, including when rapid credit growth is encouraged by incentives created by the macroeconomic policy mix. ${ }^{20}$ Since prudential measures, also in these cases, are aimed at ensuring sound lending practices and maintaining the resilience of the financial system to adverse shocks, they need not automatically be relaxed when the threat to macroeconomic stability subsides.

The room for tightening further prudential/supervisory policies varies across the CEE countries. In many of the countries, the frameworks have been strengthened significantly and there may be limited room for further tightening. In others, efforts have been ongoing to strengthen the prudential and supervisory systems, although there is still room for improvement, particularly where there are weaknesses in banks' and supervisors' ability to assess and monitor the risks. Strengthening the capability of banks and supervisors to better assess and manage indirect exposure to foreign exchange risks is an area that needs to be addressed, specifically considering the large proportion of lending in foreign currencies and limited information on the degree of hedging by borrowers in many of the CEE countries. The type of prudential/supervisory measures that could be tightened, or introduced, would in general be guided by the nature of the risks associated with the nature of the credit growth (see Table 6 for a mapping from various features of the credit growth to different types of risks, and Table 7 for the prudential instruments that could be used to deal with each type of risk).

While supervisory and prudential measures alone may not lead to a significant reduction in credit growth, they could contribute to both limiting its growth and preserving banks' asset quality, if implemented along with appropriate macro policies. In fact, there are limits to what prudential policies can do in the absence of prudent fiscal policies, or if monetary/fiscal regimes persistently create perverse incentives that encourage credit growth. Prudential policies should hence be considered as part of a comprehensive package of measures to deal with rapid credit growth. Applied in this manner, such policies can serve to address

${ }^{20}$ Macro policies generally limit credit by raising the price - the interest rate-while prudential policies tend to make such lending decisions more expensive by raising the associated costs for the banks in the form of capital requirements, provisioning rules, and liquidity requirements, or limit the quantity through, for example, loan-to-value ratios. 
distortions in bank lending associated with, for example, risky sectoral loan concentrations, unhedged currency borrowing, imprudent funding behavior by banks, or real estate bubbles. Appropriate disclosure requirements for banks of their risk management and internal control policies and practices can also strengthen market discipline, limiting imprudent lending practices.

Table 6. Key Risks Associated with Credit Growth

\begin{tabular}{|c|c|}
\hline Aspects of Credit Growth & Type of Risk Associated \\
\hline Speed of credit growth & $\begin{array}{l}\text { - Credit risk (from inappropriate loan } \\
\text { assessments, strain on ability to monitor and } \\
\text { assess risks) } \\
\text { - Macro risks }\end{array}$ \\
\hline $\begin{array}{l}\text { Main providers of credit (foreign versus domestic } \\
\text { banks, etc.) }\end{array}$ & $\begin{array}{l}\text { - Credit risk (from aggressive lending strategies) } \\
\text { - Macro risks }\end{array}$ \\
\hline Main borrowers (households, corporate sector, etc.) & $\begin{array}{l}\text { - Credit risk (greater sensitivity of repayment } \\
\text { capacity of corporate loans to the economic } \\
\text { situation, that of consumer loans to collateral } \\
\text { values) } \\
\text { - Macro risks (likely impact of loans on the } \\
\text { current account) } \\
\text { - Market risks (sensitivity to economic activity } \\
\text { and price changes) }\end{array}$ \\
\hline $\begin{array}{l}\text { Sectoral loan concentration/composition of credit } \\
\text { (mortgages, durable consumer goods, investments, } \\
\text { etc.) }\end{array}$ & $\begin{array}{l}\text { - Credit risk (from concentration, collateral } \\
\text { values for mortgages, etc.) } \\
\text { - Macro risks (impact on the current account in } \\
\text { the case of consumer/investment loans, etc.) } \\
\text { - Market risks (e.g., sensitivity to real estate } \\
\text { prices) }\end{array}$ \\
\hline Currency composition of loans & $\begin{array}{l}\text { - Direct (through banks' net open positions) and } \\
\text { indirect (via borrowers') exposure to foreign } \\
\text { exchange risk }\end{array}$ \\
\hline Maturity of loans & $\begin{array}{l}\text { - Maturity/liquidity risks (longer-term loans } \\
\text { financed through shorter-term borrowing by } \\
\text { banks) }\end{array}$ \\
\hline Sources of credit & $\begin{array}{l}\text { - Foreign exchange risk (loans funded by bank } \\
\text { borrowing) } \\
\text { - Maturity risks (when liabilities short-term, } \\
\text { assets longer term) } \\
\text { - Macro risks (from exposure to market } \\
\text { sentiment) }\end{array}$ \\
\hline
\end{tabular}

Effective implementation of the prudential/supervisory measures requires an adequate enforcement capacity, cross-border supervisory cooperation, and an effective coordination between supervisors of nonbank financial institutions. Bank and nonbank supervisory coordination is essential to avoid loopholes (e.g., a shift away from bank lending toward direct foreign borrowing or borrowing from less well-regulated and supervised nonbank financial institutions, which perform quasi-bank activities and fall outside the regulatory 


\section{Table 7. Prudential and Supervisory Measures to Manage Key Risks of Rapid Credit Growth}

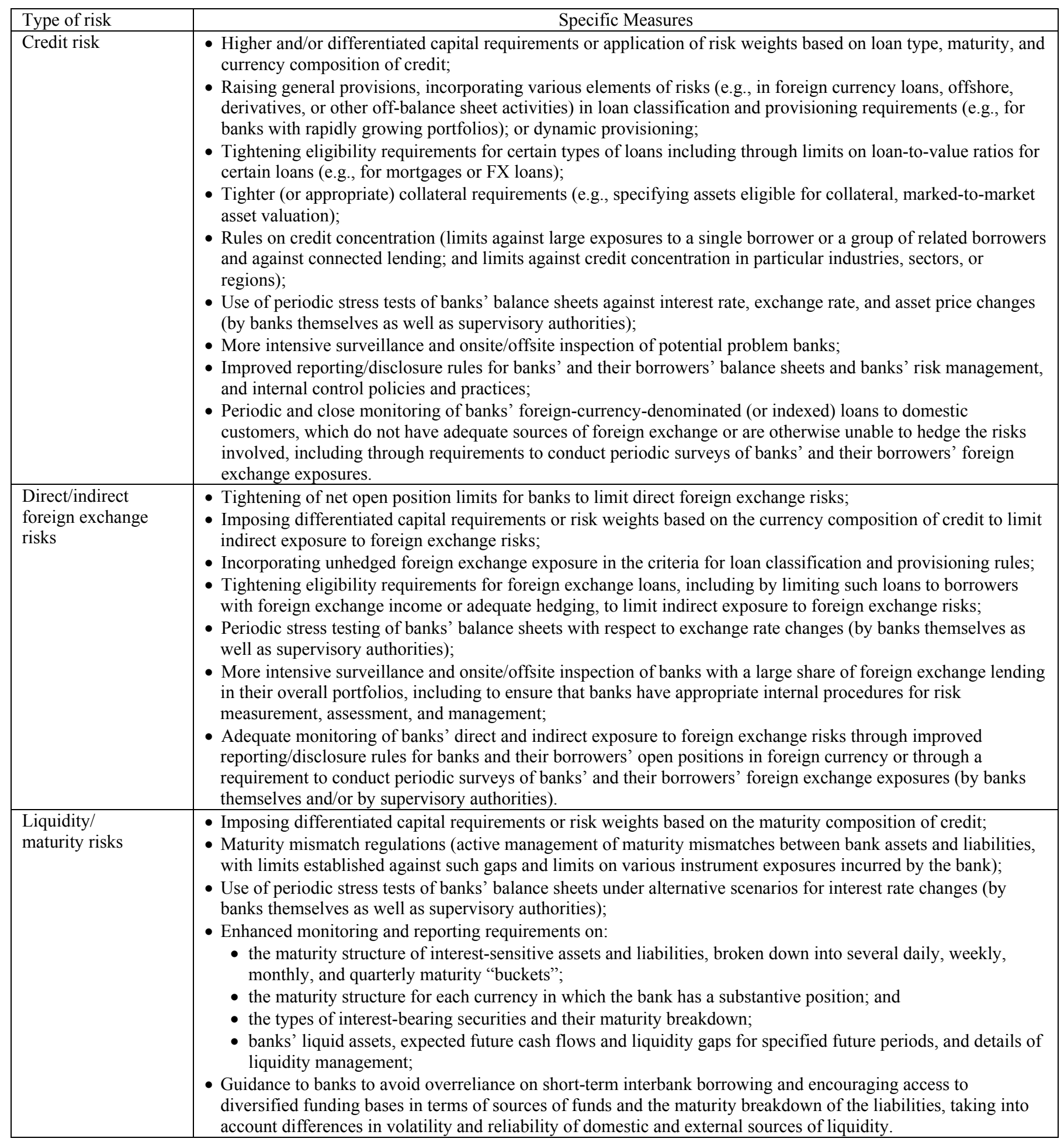

Source: Johnston and Otker-Robe (1999), Delgado and others (2000). 
framework). ${ }^{21}$ Similarly, creating an effective dialogue with home supervisors of foreign banks (e.g., through memoranda of understanding bilaterally or multilaterally or regular exchange of information among supervisors) will be critical in many of the CEE countries where rapid credit growth is dominated by a group of foreign banks regulated and supervised by home-country authorities of parent banks. This is particularly concerning since incentives to expand market share are strong and the relatively small share of the domestic banking market in foreign banks' total portfolio makes their endeavor seemingly a low-risk strategy.

Beside these policies, it is important to promote a better understanding of risks, to help limit excessive risk-taking and potential deterioration in asset portfolios. Public awareness campaigns, press conferences, seminars/workshops, financial stability reports, and "consultative" meetings with banks could be used to warn borrowers and banks against risks of over-borrowing/over-lending (some of the CEE countries have already been using these tools recently, e.g., Bulgaria and Romania). Improving the credit culture, including through credit bureaus and registries, would also help enhance market discipline, while providing a valuable information base to monitor bank loan quality. Together with a better understanding of risks, availability and use of hedging instruments would help protect banks and their customers against risks associated with rapid credit growth. This would also help deepen financial markets and enhance capacity to cope with credit growth. Developing securities markets, for example, could reduce dependence on bank credit and provide banks with alternative assets to diversify risks. ${ }^{22}$

Finally, the authorities could consider administrative measures (such as capital controls on bank borrowing, direct credit controls, financial transaction taxes, etc.), but only as a last resort, if there are significant macroeconomic and prudential risks that justify curbing the amount or growth of credit, and market participants fail to respond appropriately to changing risks over time and to other instruments. ${ }^{23}$ The decision regarding the use and timing of such measures would likely depend on the policymakers' perceptions and judgments on the vulnerability threshold of the perceived imbalances and risks. Although the probability of an adverse shock that may cause these risks to materialize may be small, the expected loss given a possible shock could be large and may prompt policymakers to take preemptive measures (in some cases drastic ones) in order to reduce the vulnerability of the system as a whole.

${ }^{21}$ International Monetary Fund (2004c) points to greater challenges for financial sector regulators brought by growing integration across various types of financial institutions and by cross-border financial integration, and the need, in turn, for closer and more systematic monitoring of cross-border contagion risks and of opportunities for regulatory arbitrage.

${ }^{22}$ A supportive borrowing strategy by the government would be essential to ensure that banks would have the incentive to invest in such instruments.

${ }^{23}$ These measures are steps back in the process of financial liberalization that took place worldwide during the past decades; see Abiad and Mody (2003). 
Since administrative measures are distortionary and entail costs (see, e.g., Alexander, Balino, and Enoch, 1995), including for the stability of the financial system that the measures intend to protect, a careful cost-benefit analysis is needed before such measures are adopted. Such analysis should take the potential risks into consideration and periodically assess the risk of circumvention through balance sheet manipulation by banks and borrowers switching to less supervised and monitored nonbank financial institutions for funding (direct credit controls were used in Croatia, for example, where such effects have been observed, and were subsequently removed). Imposing administrative measures may also send a negative signal of a lack of commitment to market-based policies, and the authorities should have sufficient confidence that the costs of resorting to such measures would not exceed their expected benefits. Since these measures likely have unintended and undesirable side effects, they should be temporary and designed to include some market-based features, to the extent possible, to avoid introducing long-lasting distortions and inefficiencies. ${ }^{24}$

\section{SUMMARY AND CONCLUDING REMARKS}

Rapid growth in credit to the private sector continues to be a key challenge for most of the CEE countries. The rapid pace of credit expansion in these countries, generally from a low base, is likely driven by a "catching up" process. It is supported by an upward revision in income expectations due to improving economic prospects, often related to the prospect of EU accession. On the supply side, foreign financial institutions entering these markets with the objective of rapidly gaining market share have often facilitated funding the rapid expansion of credit. For these foreign institutions, the exposure to any particular country is often still limited. All this, however, does not mean that the process is without danger, and in fact the pattern shows similarities to experiences of other countries where (over)optimism about future earnings led to a boost in asset valuations and a surge in capital inflows that allowed firms and households to borrow and spend.

Key macroeconomic implications of rapid credit growth include inflation and a weakening of the current account; in the CEE countries, the latter has been more prominent. Continued deterioration in external balances of the CEE countries may increase the risk of speculation against the currencies under the prevailing fixed exchange rate regimes. The low savings rates in most of the countries imply that they are highly dependent on the willingness of foreign investors to fund these deficits.

From a microeconomic perspective, it is not clear whether the credit risk systems of banks in the CEE market will be able to cope with a potential lending boom. In most of the CEE countries, the prudential indicators do not signal a significant vulnerability of the banking

${ }^{24}$ Reserve requirements on excessive credit growth or on banks' foreign borrowing (including from their parent banks), for example, may discourage excessive lending by making it more costly for the bank, rather than limiting credit outright. 
system, but many of these are lagging and not leading indicators. Moreover, there have been some indications of a decline in capital adequacy and some increase in credit risks in many of the countries in the group. In these countries rapid credit growth-in particular in cases where the number of credit applications grows rapidly - has started to put a strain on banks' and bank supervisors' capacity to assess risks. Furthermore, a sharper-than-expected decline in interest margins, due to increased competition, may decrease the profitability of the banking system and increase its vulnerability.

These macroeconomic and microeconomic implications of rapid credit growth entail two different but interrelated risks. On the one hand, in a situation of continued macro instability (inflation and/or external imbalances), financial stability will come under pressure. On the other hand, financial instability — a weak and vulnerable financial system - will contribute to macroeconomic imbalances. Addressing these risks generally calls for a comprehensive policy response, in which monetary and fiscal policies should be supplemented and supported by prudential and supervisory policies.

The starting point for any policy response should be an assessment of credit growth on the basis of detailed underlying data. It is important to monitor and analyze a breakdown of aggregate credit data in terms of the borrower, the purpose of the loan, the currency denomination, and other relevant conditions of the loans. Such a breakdown is necessary for an assessment of the possible macroeconomic as well as financial stability risks involved. Without such a comprehensive assessment, it will generally not be possible to determine whether and when an observed rate of credit growth is a cause for concern, given the difficulties in assessing the appropriate rate of growth in countries experiencing substantial structural change. The assessment should also include macroeconomic, macroprudential, and structural factors, including the existence of macroeconomic imbalances, the soundness and strength of the financial system, the effectiveness of supervision and regulation, the structure of the financial system, and the financial health of borrowers.

Once the need for a policy response has been established, the authorities can draw on a variety of instruments at their disposal, and many of the countries in the region have in fact resorted to a number of measures in response to rapid credit expansion. The effectiveness of these measures has varied and has been affected by a number of factors, including the openness of the capital account, the degree of euroization of the economies, the adequacy of monetary instruments and the effectiveness of monetary policy transmission, as well as the fiscal position.

Looking forward, for most countries in the region there seems to be room to use a combination of macro and prudential measures to address causes as well as consequences of credit growth. Monetary policy could be used effectively, provided that efforts are put into developing effective market-based monetary instruments and to eliminating obstacles to a smooth functioning of the transmission mechanism. Yet for other countries, the set of available measures may be more limited due to their specific characteristics. In particular, in some of the CEE countries the ability to use monetary policy is constrained by the prevailing exchange rate regimes and the openness of the capital account. Fiscal policy can also be used 
to reduce demand pressures. However, the scope for a fiscal policy response may be limited in cases where the fiscal position is already relatively strong and overfunding is politically difficult.

It is clear that the use of prudential measures needs to be justified by prudential considerations, with a particular focus on ensuring sound lending practices. This should be the case regardless of the rate of credit growth. As noted above, in cases where there exist serious concerns about macroeconomic stability, that is likely to have a bearing on financial stability as well. If so, prudential and supervisory measures can support macro policies to stem credit growth. The supervisory authorities first need to make sure that the existing prudential and supervisory rules are adequately enforced. Additional prudential and supervisory measures could be introduced depending on the types of risks involved. In order to ensure the effectiveness of these measures, there should be effective coordination between the supervision of bank and nonbank financial institutions as well as close and strong cross-border supervisory cooperation. The exposure of foreign banks to individual CEE countries may be small, but to the region as a whole it is rapidly growing, which makes cross-border exchange of information and cooperation between supervisors a key requirement.

Moreover, it is essential to promote a good understanding of risk, including through public awareness campaigns against overborrowing and overlending. This applies in particular to borrowing in foreign exchange, where foreign exchange risks for unhedged borrowers can easily translate into credit risks for the banks. Credit bureaus can help banks' assessment of the quality of borrowers. Furthermore, further developing financial markets in these countries would help improve the transmission mechanism, as well as facilitating hedging by banks and their customers against various risks associated with credit growth. Developing financial markets, including securities markets, could also provide banks with alternative investment opportunities and reduce the pressure on lending.

Administrative measures should be considered only as a last resort. Since these measures have unintended and undesirable side effects - such as impeding competition and circumvention through nonbank and foreign institutions, as well as undermining market confidence - they should at most be imposed temporarily and designed carefully to avoid introducing long-lasting distortions and inefficiencies. Also in this case, effective coordination between of bank and nonbank supervision and cross-border supervisory cooperation would be critical to ensure the effectiveness of such measures. 


\section{References}

Abiad, A., and A. Mody, 2003, "Financial Reform: What Shakes It? What Shapes It?" IMF Working Paper 03/70 (Washington: International Monetary Fund).

Alexander, W. E., T. J.T. Balino, and C. Enoch, 1995, The Adoption of Indirect Instruments of Monetary Policy, IMF Occasional Paper 126 (Washington: International Monetary Fund).

Ariyoshi, A., K. Habermeier, B. Laurens, I. Otker-Robe, J. Canales-Kriljenko, and A. Kirilenko, 2000, Capital Controls: Country Experiences with their Use and Liberalization, IMF Occasional Paper 190 (Washington: International Monetary Fund).

Banco de España, 2002, “Asset Price Bubbles: Implications for Monetary, Regulatory, and International Policies", Speech by the Governor given at the Federal Reserve Bank of Chicago, http://www.bde.es/prensa/intervenpub/gobernador/220402e.htm.

Banco de Espana, 2002, "Dynamic Provisioning in Spain: Impacts of the New Spanish Statistical Provision in the Second Half of 2000," http://www.bde.es/provesta/impactoe.htm.

Bank for International Settlements, 2005, Real Estate Indicators and Financial Stability, BIS Papers No. 21 (Basle: Bank for International Settlements).

Bernanke, B., and M. Gertler, 1995, "Inside the Black Box: Credit Channel of Monetary Policy Transmission,” 1995, NBER Working Paper No. 5146 (Cambridge, Massachusetts: National Bureau of Economic Research), pp.1-43.

Bernanke, B., M. Gertler, and S. Gilchrist, 1999, "The Financial Accelerator in Quantitative Business Cycle Framework," Handbook of Macroeconomics, Vol. 1C, pp. 1341-93, Handbooks in Economics, Vol. 15. (New York: Elsevier Science, North-Holland).

Borio, C., C. Furfine, and P. Lowe, 2001, "Procyclicality of Financial Systems and Financial Stability," BIS Papers No. 1 (Basle: Bank for International Settlements).

Borio, C., and P. Lowe, 2002, “Asset Prices, Financial and Monetary Stability: Exploring the Nexus,” BIS Working Paper No. 114 (Basle: Bank for International Settlements).

Breyer, P., 2004, "Central and Eastern Europe - the Growth Market for Austrian Banks," Monetary Policy and the Economy, Issue Q3/04 (Vienna: Austrian National Bank).

Caprio, G. and D. Klingebiel, 2003, Episodes of Systemic and Borderline Crises (Washington: World Bank).

Cottarelli, C., G. Galli, P. Marullo Reedtz, and G. Pittaluga, 1986, "Monetary Policy Through Ceilings on Bank Lending," Economic Policy (October). 
Cottarelli, C., G. Dell'Ariccia, and I. Vladkova-Hollar, 2003, “Early Birds, Late Risers, and Sleeping Beauties: Bank Credit Growth to the Private Sector in Central and Eastern Europe and the Balkans," IMF Working Paper No. WP/03/213 (Washington: International Monetary Fund).

Delgado F. L., D. S. Kanda, G. Mitchell Casselle, and R. A. Morales, 2000, “Banks’ Domestic Lending in Foreign Currency," MAE Operational Paper, No. OP/00/4 (Washington: International Monetary Fund).

Demirguc-Kunt, A., and E. Detragiache, 1997, “The Determinants of Banking Crises Evidence from Developing and Developed Countries," IMF Working Paper No. WP/97/106 (Washington: International Monetary Fund).

Drees, B., and C. Pazarbasioglu, 1995, “The Nordic Banking Crisis: Pitfalls in Financial Liberalization?” IMF Working Paper No. WP/95/61 (Washington: International Monetary Fund).

Duenwald, Christoph, Nikolay Gueorguiev, and Andrea Schaechter, "Too Much of A Good Thing? Credit Booms in Transition Economies: The Cases of Bulgaria, Romania, and Ukraine," IMF Working Paper No. WP/05/128 (Washington: International Monetary Fund).

Esquivel, G., and F.. Larrain B., 1998, "Explaining Currency Crises," Development Discussion Paper, No. 666 (Cambridge, Massachusetts: Harvard Institute for International Development), pp. 1-36 (November).

Favara, G., 2003, "An Empirical Reassessment of the Relationship Between Finance and Growth,” IMF Working Paper No. WP/03/123 (Washington: International Monetary Fund).

Feldman, R. A., and C. M. Watson, 2002, Into the EU-Policy Frameworks in Central Europe (Washington: International Monetary Fund).

Fernandez de Lis, S., J. M. Pages, and J. Saurina (2000), "Credit Growth, Problem Loans, and Credit Risk Provisioning in Spain,” Paper prepared for the Bank for International Settlements Autumn Central Bank Economists’ Meeting (Madrid: Banco de Espana).

Fuerst, T., 1995, "Monetary and Financial Interactions in the Business Cycle," Journal of Money, Credit and Banking, Vol. 27 (November), pp. 1321-38.

Goldfajn, I., and R. Valdes, 1997, "Capital Flows and the Twin Crises: Role of Liquidity," IMF Working Paper No. WP/97/87 (Washington: International Monetary Fund).

Goldstein, M., 2001, “Global Financial Stability: Recent Achievements and Ongoing Challenges," Global Public Policies and Programs: Implications for Financing and Evaluation, Proceedings from a World Bank Workshop (Washington: World Bank), pp. 157-61. 
Gourinchas, P., R. Valdes and O. Landerretche, 2001, "Lending Booms: Latin America and the World," Economia, Vol. 1., pp. 47-99.

Gulde, A., 1995, “Liquid Asset Ratios as a Tool?” MFD Operational Paper (Washington: International Monetary Fund).

Hilbers, P., Q. Lei, and L. Zacho, 2001, "Real Estate Market Development and Financial Sector Soundness," IMF Working Paper No. WP/01/129 (Washington: International Monetary Fund).

Hodrick, R. J., and Prescott, E. C.,1997, "Postwar U.S. Business Cycles: An Empirical Investigation," Journal of Money, Credit and Banking, Vol. 29, No. 1, pp. 1-16.

International Monetary Fund, 2004a, "Are Credit Booms in Emerging Markets a Concern?" World Economic Outlook, April 2004, Chapter IV.

International Monetary Fund, 2004b, “Bulgaria's Credit Boom: Characteristics, Consequences and Policy Options", Selected Issues and Statistical Appendix,Country Report 04/177.

International Monetary Fund, 2004c, Financial Sector Regulation: Issues and Gaps (August) (Washington: International Monetary Fund).

International Monetary Fund, 2005a, Financial Sector Assessment Program-Review, Lessons and Issues Going Forward (Washington: International Monetary Fund).

International Monetary Fund, 2005b, "Credit Boom in Ukraine: Risks for Banking Sector Stability," Selected Issues and Statistical Appendix, Country Report 05/20.

Johnston, B., and I. Otker-Robe, 1999, "A Modernized Approach to Managing the Risks in Cross-Border Capital Movements," IMF Policy Discussion Paper, PDP/99/6 (Washington: International Monetary Fund).

Kaminsky, G., and C. Reinhart, 1999, “The Twin Crises: The Causes of Banking and Balanceof-Payments Problems," American Economic Review Vol. 89, No. 3, pp. 473-500.

Kaminsky, G., S. Lizondo, and C. Reinhart, 1997, "Leading Indicators of Currency Crises," IMF Working Paper No. WP/97/79 (Washington: International Monetary Fund).

Kindleberger, C. P.,1996, "The Lender of Last Resort: Pushing the Doctrine Too Far?," Monetary Economics in the 1990s: The Henry Thornton Lectures, Numbers 9-17 (New York: St. Martin's Press), pp. 122-36.

King, R. G., and R. Levine, 1993, "Finance and Growth: Schumpeter May Be Right," Quarterly Journal of Economics Vol. 108, No. 3, pp. 717-37. 
Kiyotaki, N., and J. Moore, 1997, "Credit Cycles," Journal of Political Economy Vol. 105, No. 2, pp. 211-48.

Kraft E., and L. Jankov, 2005, "Does Speed Kill? Lending Booms and Their Consequences in Croatia," Journal of Banking and Finance 29, pp. 105-21.

Lukonga, I., and K. Nakamura, 2003, "Private Sector Credit Expansion in Selected Eastern European Countries: Developments, Risks, and Policy Issues," (Washington: International Monetary Fund), unpublished.

Levine, R., 1997, "Financial Development and Economic Growth: Views and Agenda," Journal of Economic Literature, Vol. 35, No. 2, pp. 688-726.

Maechler, A., and M. Swinburne, 2005, Rapid Credit Growth and Policy Responses, Monetary and Financial Systems Department, (Washington: International Monetary Fund), unpublished.

Mann, F., and I. Michael, 2002, "Dynamic Provisioning: Issues and Application," Financial Stability Review, Issue No. 13 (London: Bank of England).

Minsky H. P., 1992, Profit, Deficits and Instability (London: Macmillan Academic and Professional), pp. 11-22.

Otker, I., and C. Pazarbasioglu, 1997, "Speculative Attacks and Macroeconomic Fundamentals: Evidence From Some European Currencies," European Economic Review, Vol. 41, No. 3-5, pp. 847-60 (April).

Romain R., A. Tornell, and F. Westermann, 2005, "Systemic Crisis and Growth,” NBER Working Paper No. 11076 (Cambridge, Massachusetts: National Bureau of Economic Research).

Schadler, S., P. Drummand, L. Kuijs, Z. Murgasova, and R. van Elkan, 2004, Adopting the Euro in Central Europe-Challenges of the Next Step in European Integration, IMF Occasional Paper 234 (Washington: International Monetary Fund).

Sundararajan, V., C. Enoch, A. San Jose, P. Hilbers, R. Krueger, M. Moretti, and G. Slack, 2002, Financial Soundness Indicators: Analytical Aspects and Country Practices, IMF Occasional Paper 212 (Washington: International Monetary Fund).

Watson, M., 2004, "Financial Stability in Converging Economies: Macro-prudential Challenges," unpublished. 


\section{Data and Methodology}

\section{Data}

The dataset is comprised of two groups of countries: a focus group and a benchmark group. The focus group is a set of 18 countries defined as having been involved in the transition process from centralized planning to a market economy, primarily located in Central and Eastern Europe. The focus group forms a panel of annual data from 1990 to 2004. The benchmark group is a panel of annual data of 37 countries through the period 1980-2004. The benchmark group was selected from countries within the Organization for Economic Cooperation and Development (OECD) that have experienced above average economic growth and countries that did experience rapid credit growth during the period. Financial crisis countries are those countries which Caprio and Klingenbiel (2003) identified as having experienced systemic banking crisis during 1980-2003.

Most variables in the sample were obtained from International Financial Statistics (IFS). Measures of GDP and CPI were taken from the World Economic Outlook Database. Financial soundness indicators were taken from an IMF database.

Bank credit to the private sector is measured as claims that commercial banks have on the private sector, i.e., line $22 \mathrm{~d}$ in the IFS, and GDP in current prices of each country's national currency. Note, however, that line $22 \mathrm{~d}$ is a conservative measure of credit. Credit extended by leasing companies and other nonbank financial institutions is not included. Due to lack of data in various countries, as well as to permit cross-country comparisons, line $22 \mathrm{~d}$ has been used to assess credit expansion in the countries covered in the paper. ${ }^{25}$ Since credit is a stock variable and GDP is a flow variable the ratio is determined by bank credit to the private sector at the end of time $t$ divided by the simple average of GDP over time $t$ and $t+1$ :

$$
\text { Credit_ratio }=\frac{B C P R S_{t}}{\left(G D P_{t}+G D P_{t+1}\right) / 2}
$$

\section{How to detect credit booms?}

The study follows the method developed by Gourinchas, Valdes, and Landerretche (2001) when identifying credit booms and rapid credit growth episodes. In order to determine the cycles, they establish a trend of credit to GDP over time, using the recursive (or rolling) Hodrick Prescott filter ("HP filter"). The HP filter decomposes a series into a trend $\left(\mathrm{x}_{\mathrm{t}}\right)$ and a

\footnotetext{
${ }^{25}$ Country reporting of credit extended to the economy varies substantially. Using only line $22 \mathrm{~d}$ as a measure of credit to the private sector may, of course, underestimate the extent of credit growth, where most credit to the private sector is intermediated by leasing companies and other nonbank financial institutions (as in the case of Romania, for example).
} 
stationary component $\left(\mathrm{y}_{\mathrm{t}}-\mathrm{x}_{\mathrm{t}}\right)$, where $\mathrm{y}_{\mathrm{t}}$ represents the actual credit ratio, by choosing $\mathrm{x}_{\mathrm{t}}$ such that the following formula is minimized (Hodrick and Prescott, 1997):

$\min \left\{\sum_{t=1}^{T}\left(y_{t}-x_{t}\right)^{2}+\lambda \sum_{t=2}^{T-1}\left(\left(x_{t+1}-x_{t}\right)-\left(x_{t}-x_{t-1}\right)\right)^{2}\right\}$

$\lambda$ is a smoothing parameter, usually set at 1600 for quarterly data and 1000 for annual data. If $\lambda=0, x_{t}$ will be minimized when $x_{t}=y_{t}$.

The recursive HP filter sets a trend at each data point by de-trending the first 5 years, then calculating a trend for the first 6 years, and another for the first 7 years, etc. The last trend point for each exercise makes up the trend for the whole series. This method enables the policymaker to identify whether a boom has occurred up until the time a decision has to be made, hence identify where the economy is located in the cycle at any given point in time.

Gourinchas, Valdes and Landerretche (2001) calculate the relative difference and absolute difference between the actual series and the trend, where the relative difference

equals $\frac{\left(y_{t}-x_{t}\right)}{x_{t}}$. In our analysis, we opted for the relative difference approach rather than the absolute difference, to take into consideration the level of financial deepening in assessing how concerning credit growth could be (e.g., a rise in private credit to GDP from 10 percent to the 20 percent will have a much different expansionary effect on macroeconomic variables than a rise from 100 percent to 110 percent).

To identify the start of a rapid credit growth episode and a possible boom in credit extended to the private sector, Gourinchas, Valdes and Landerretche (2001) set an arbitrary limit threshold at 5 percent relative difference and 2 percent absolute difference. They rank in a descending order the relative and absolute difference of all observations in their dataset and set a cut-off point for the credit boom at the $60^{\text {th }}$ highest deviation, the $80^{\text {th }}$ and the $100^{\text {th }}$ cases, which yield cut-off points in terms of relative difference at 24.0 percent, 19.5 percent, and 16.4 percent of relative difference, respectively. The observations that exceed the threshold made by the cut-off points are identified as booms. The cut-off points for our dataset are at 34.5 percent, 28.0 percent, and 22.2 percent for the $60^{\text {th }}, 80^{\text {th }}$ and the $100^{\text {th }}$ case; hence all observations with the relative difference exceeding 22.2 percent are considered as booms in our analysis.

A word of caution may be warranted regarding the identification process. The method described above, although widely used, has certain shortcomings. The identification of a boom in a given country is highly dependent on the dataset at hand. Should one particular country experience a profound and longlasting credit boom, it may crowd out credit booms in other countries from the list of 60,80 , or 100 cases that the method suggests. That indeed was observed as the credit crisis in the Nordic countries in the late 1980s and early $1990 \mathrm{~s}$ were not included in the 100 case list as the data from 1980-2004 were explored. Our examination provides evidence that the cut-off point, which defines the limit threshold, has 
risen over time, hence the credit expansion in the Nordic countries is not defined as a boom in our exercise.

Furthermore, if an output shock occurs but credit remains unchanged, one may detect a credit boom where there is no such boom. Further work is needed to develop a methodology to identify credit booms which takes the above mentioned weaknesses into account. 
-42 -

\begin{tabular}{|c|c|c|}
\hline 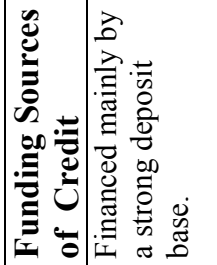 & 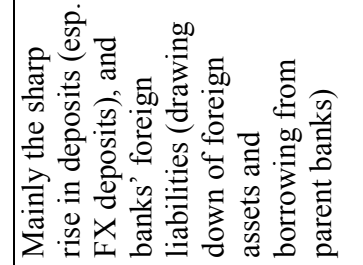 & 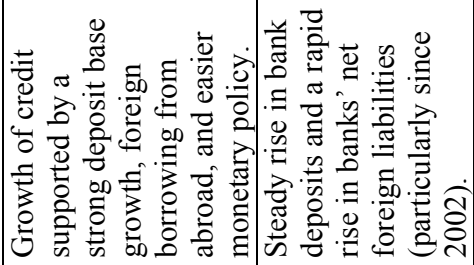 \\
\hline
\end{tabular}

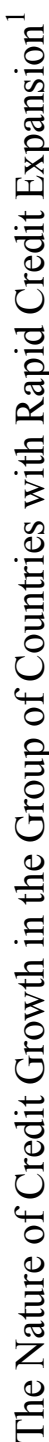

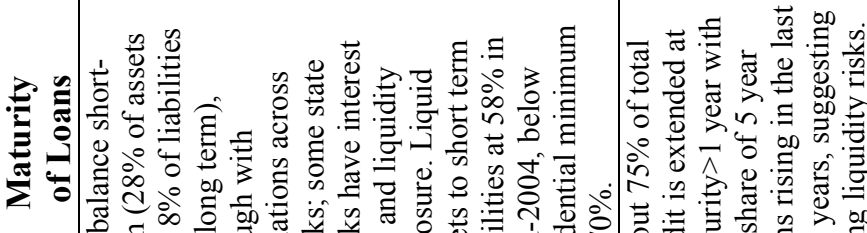

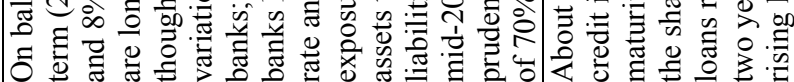

里

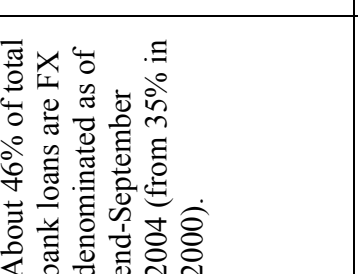

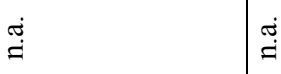

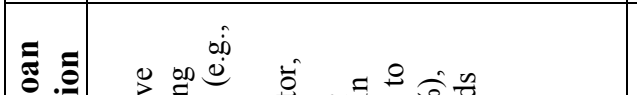

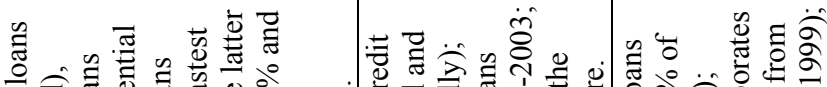

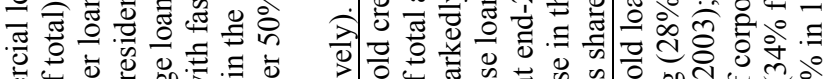

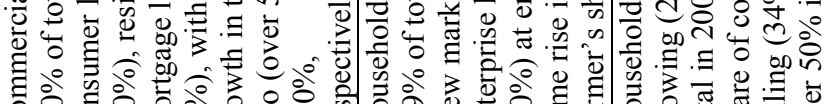

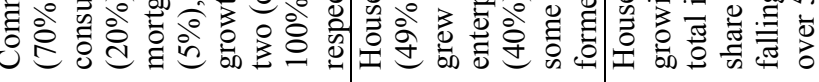

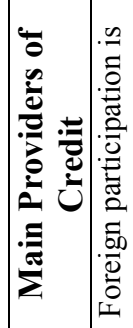

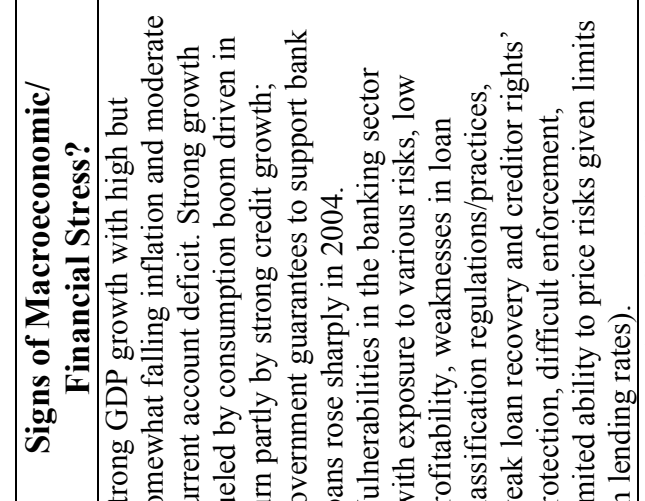

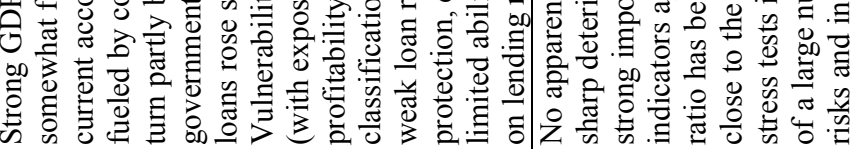

\begin{tabular}{|c|c|c|c|c|}
\hline 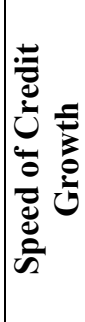 & 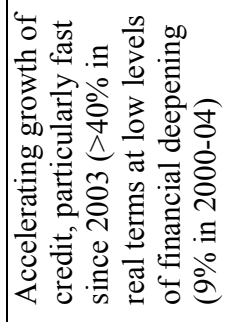 & 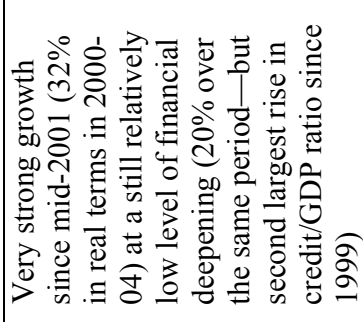 & 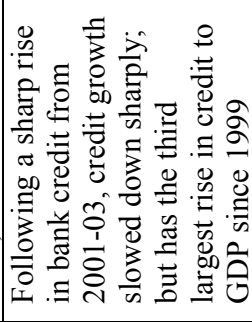 & 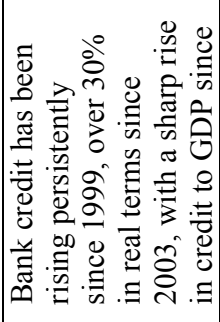 \\
\hline & 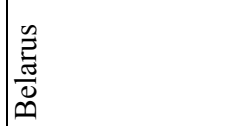 & 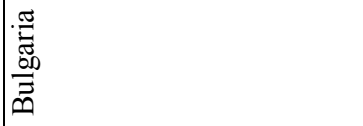 & 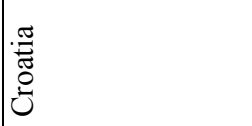 & 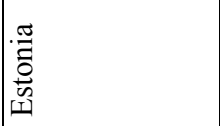 \\
\hline
\end{tabular}




\begin{tabular}{|c|c|c|c|c|c|}
\hline 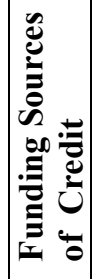 & 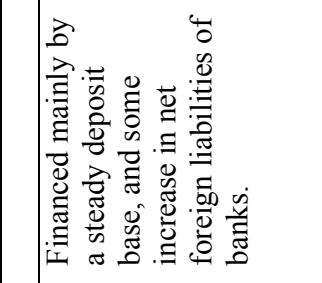 & 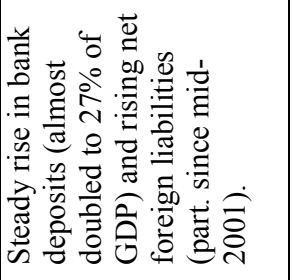 & 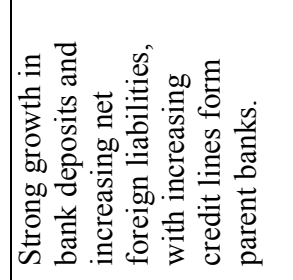 & 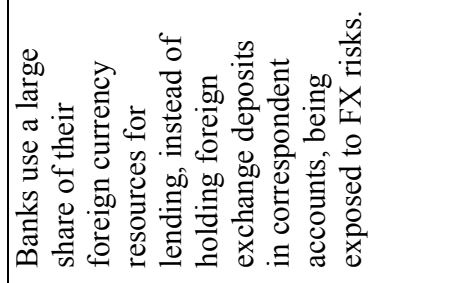 & $\sum_{\bar{\pi}}^{\bar{\pi}}$ \\
\hline 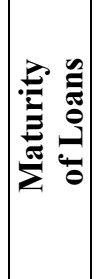 & 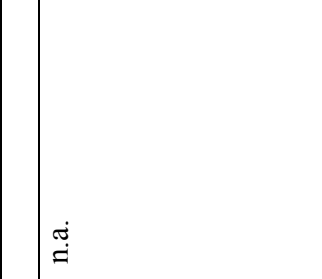 & 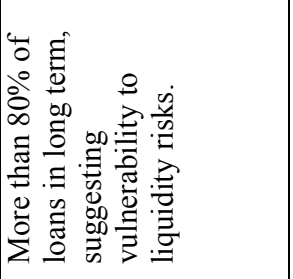 & 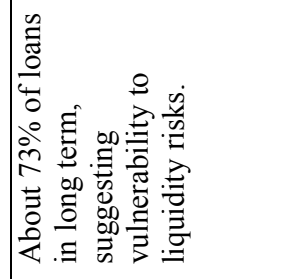 & 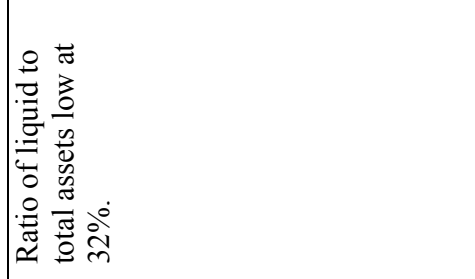 & 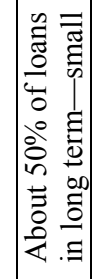 \\
\hline 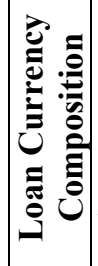 & 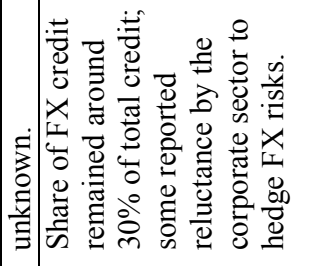 & 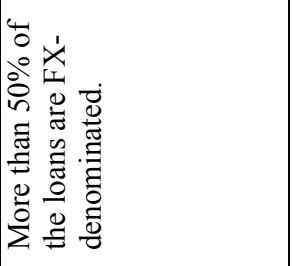 & 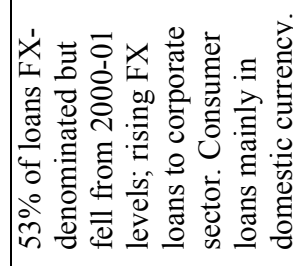 & 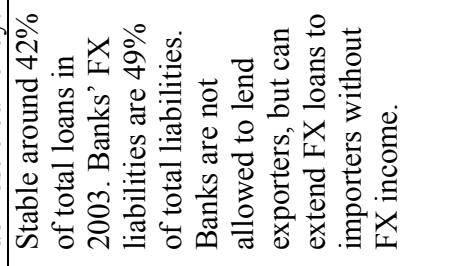 & \\
\hline 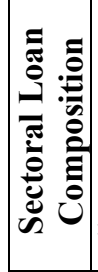 & 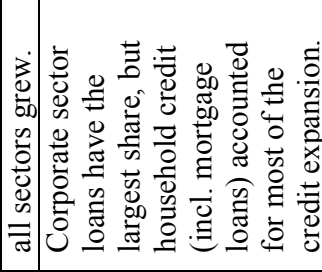 & 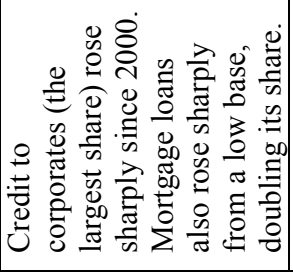 & 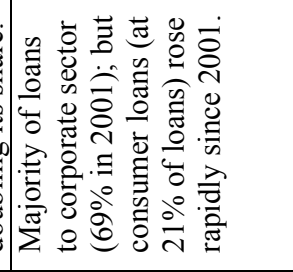 & 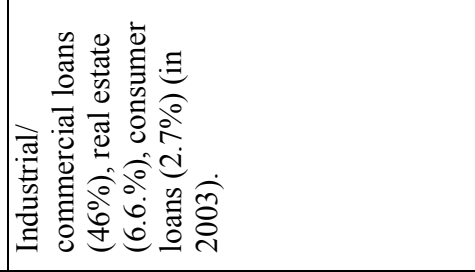 & \\
\hline 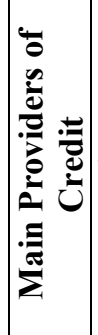 & 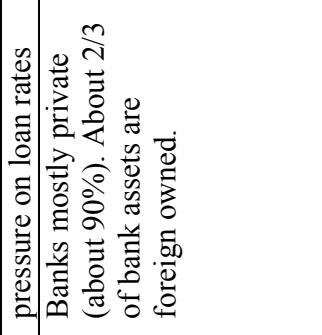 & 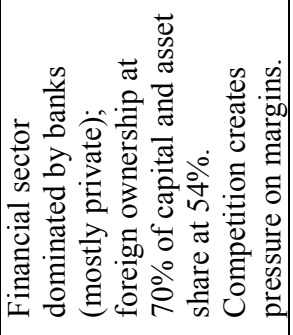 & 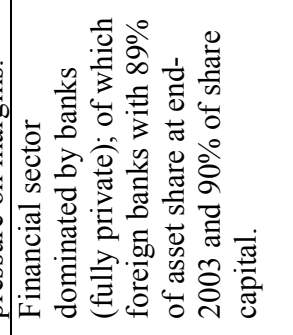 & 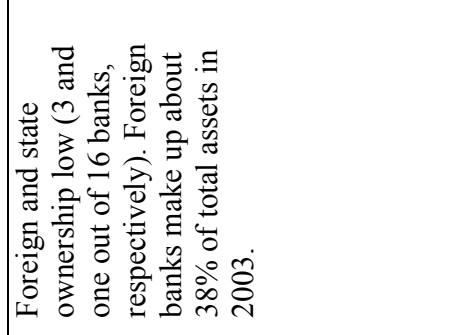 & \\
\hline 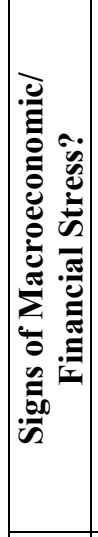 & 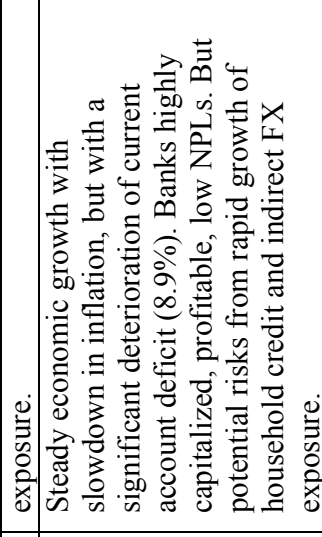 & 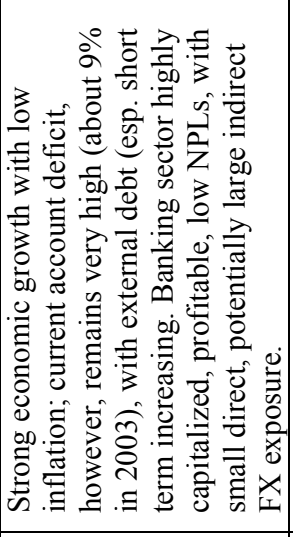 & 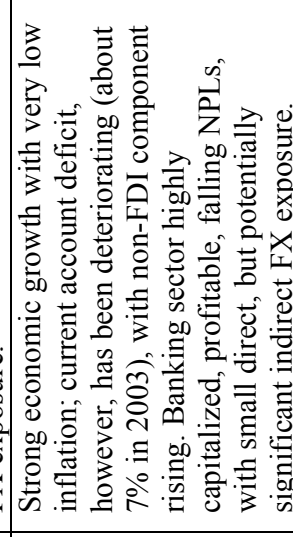 & 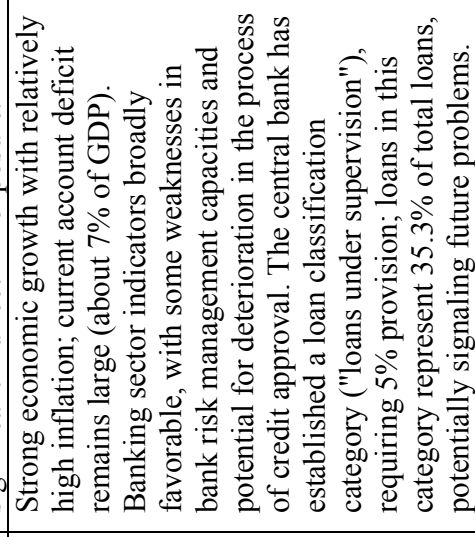 & \\
\hline 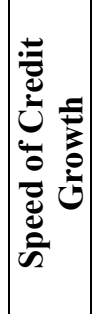 & 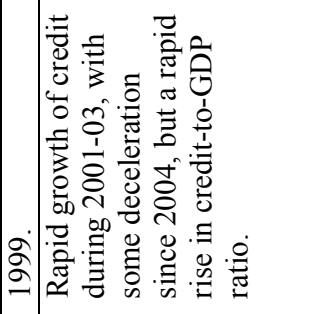 & 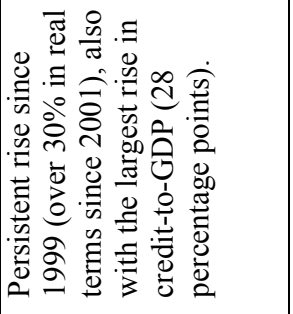 & 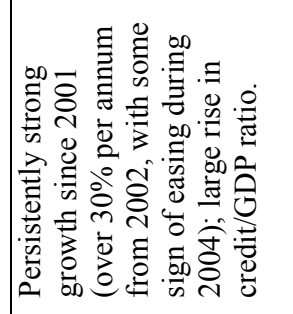 & 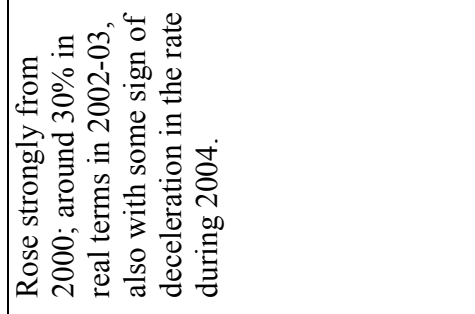 & Ũ. \\
\hline & $\begin{array}{l}\text { 志 } \\
\text { o. } \\
\Xi \\
\text { 至 }\end{array}$ & 离 & 墨 & $\frac{\dot{z}}{\frac{0}{0}}$ & (2) \\
\hline
\end{tabular}




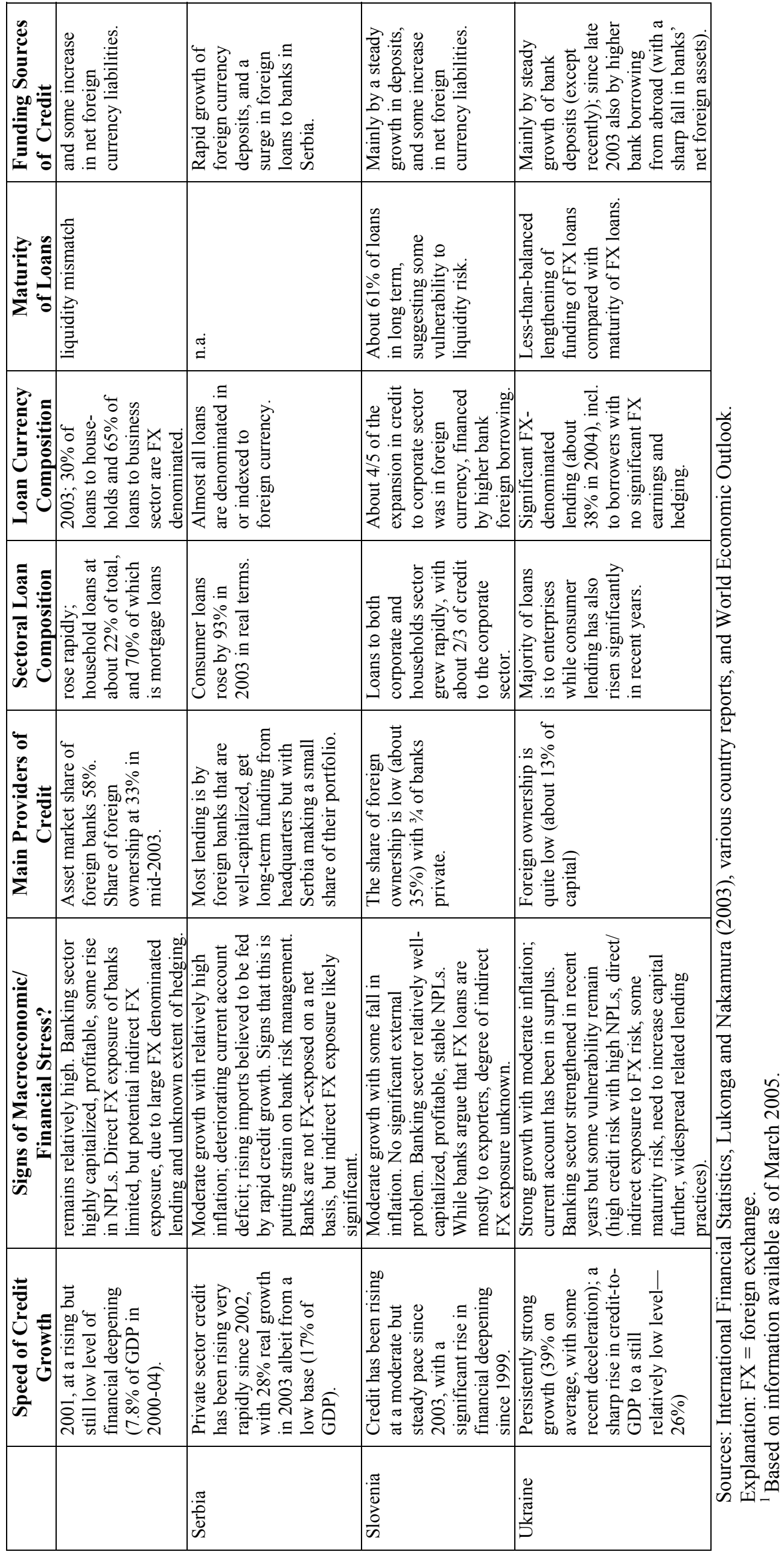




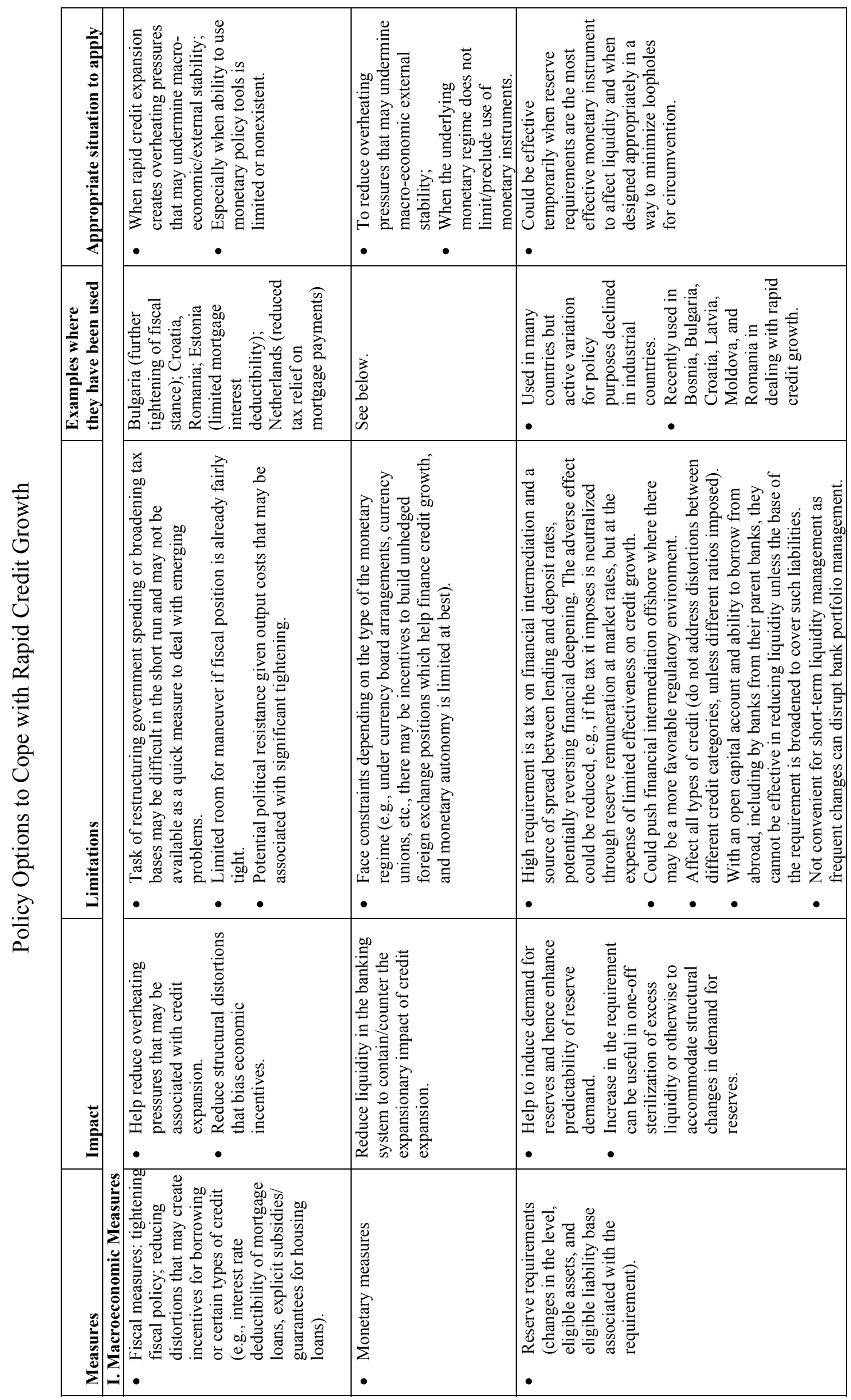




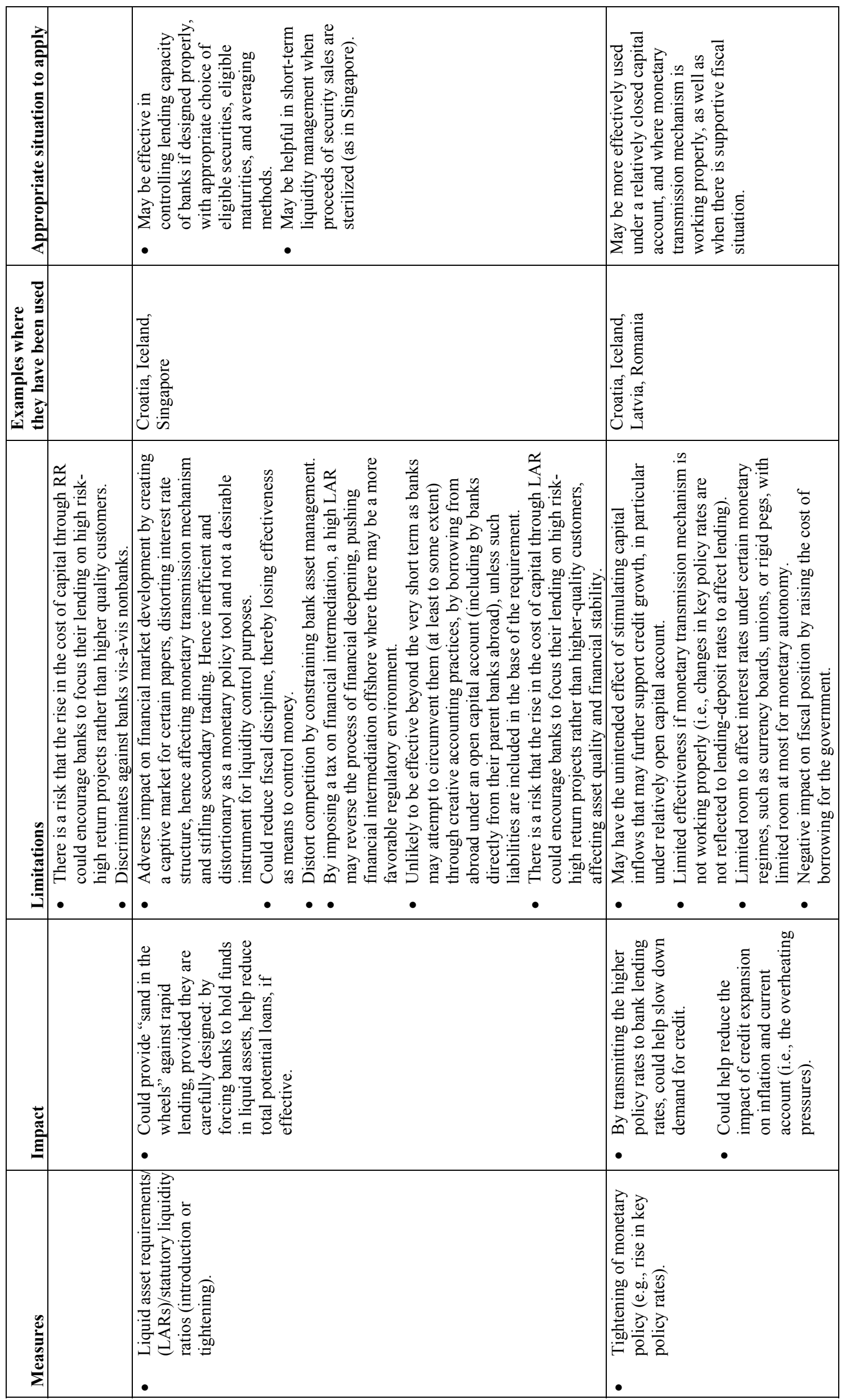




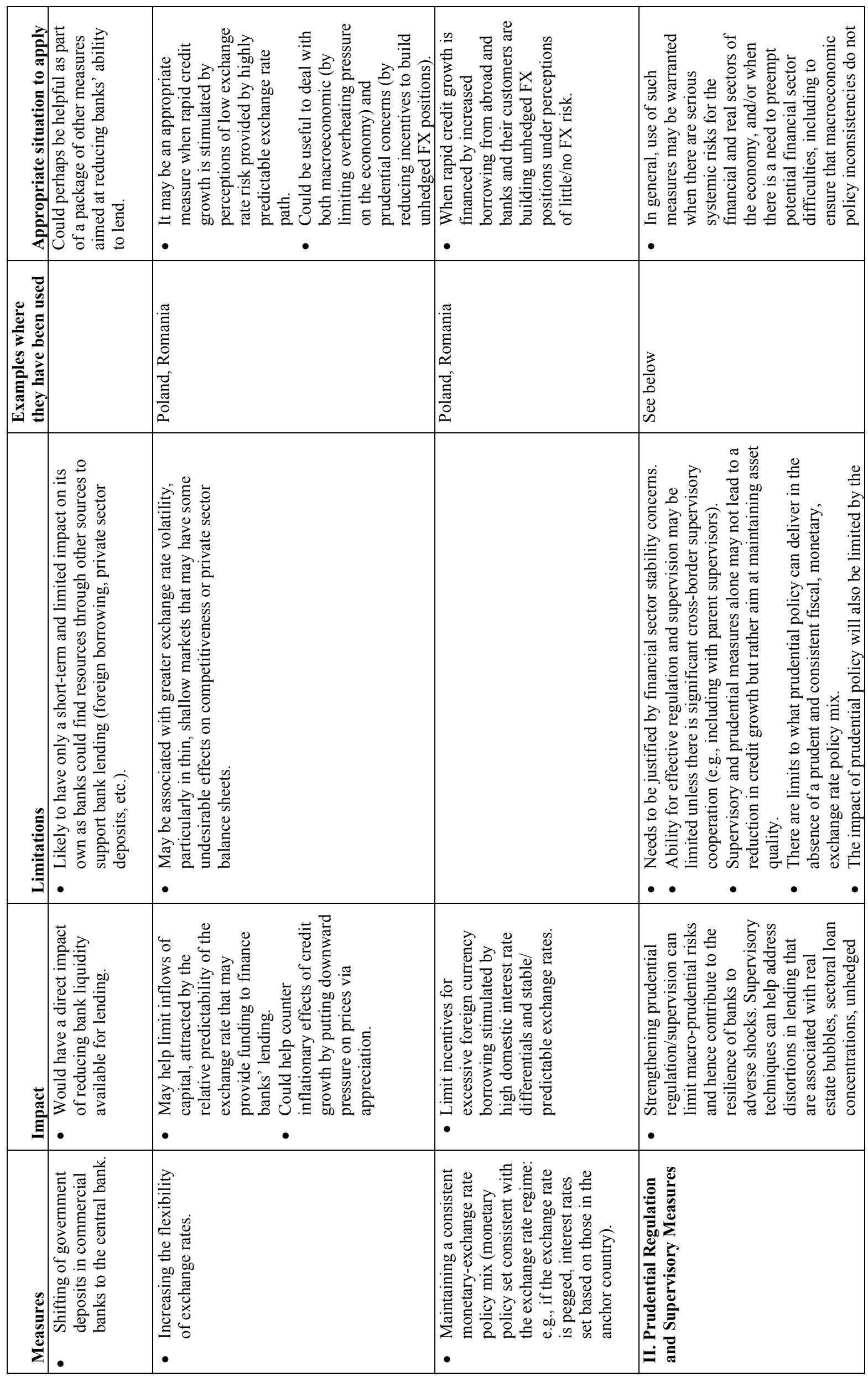




\begin{tabular}{|c|c|c|c|c|c|}
\hline & 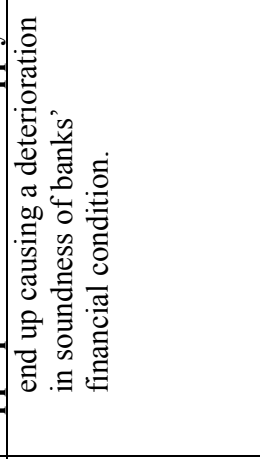 & & 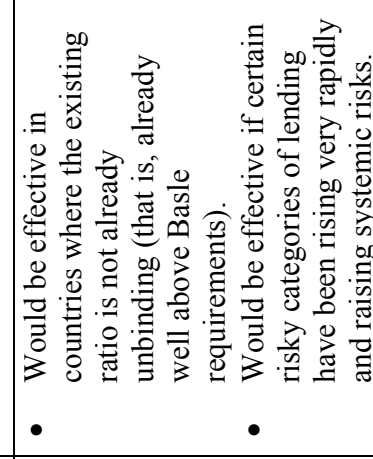 & 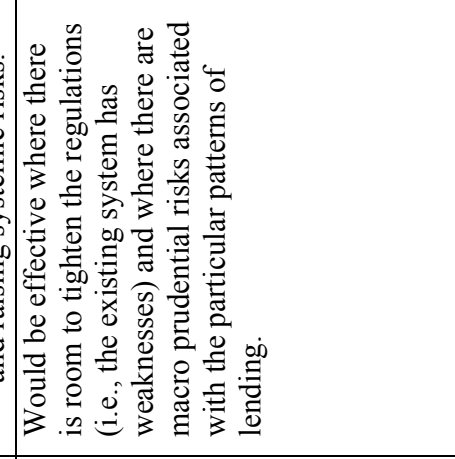 & 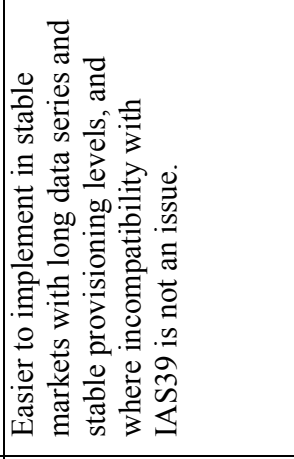 \\
\hline & & & 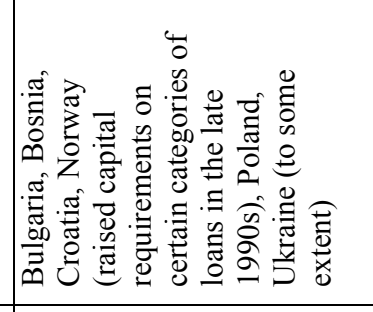 & 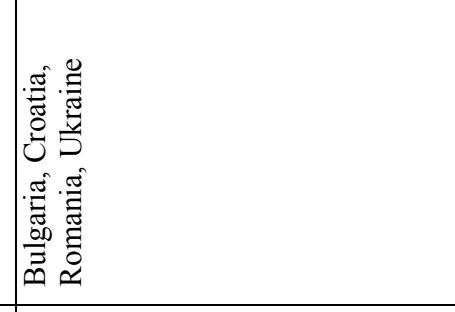 & 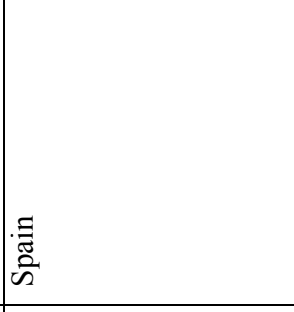 \\
\hline & 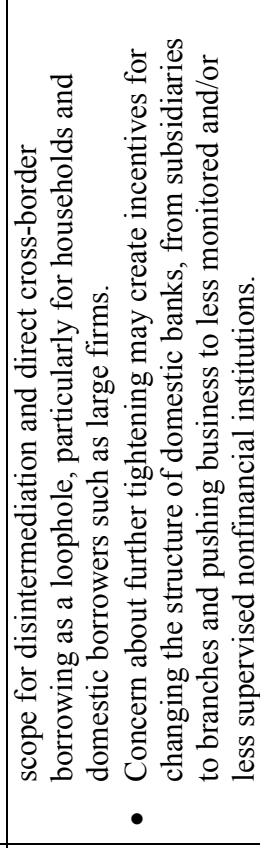 & & 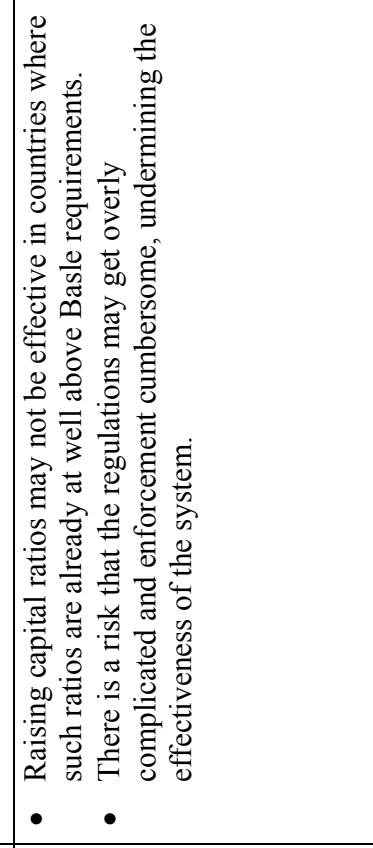 & 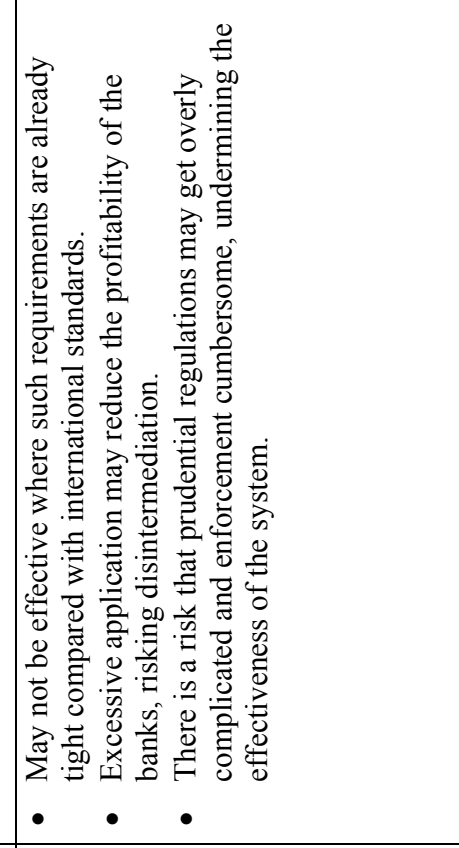 & 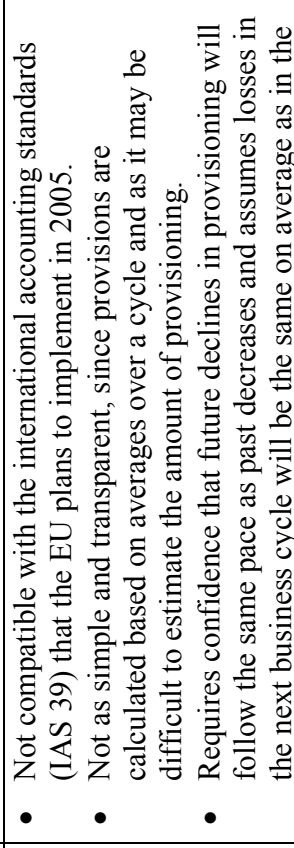 \\
\hline & 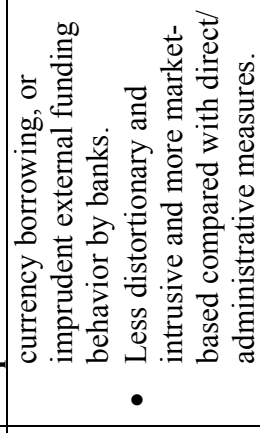 & & 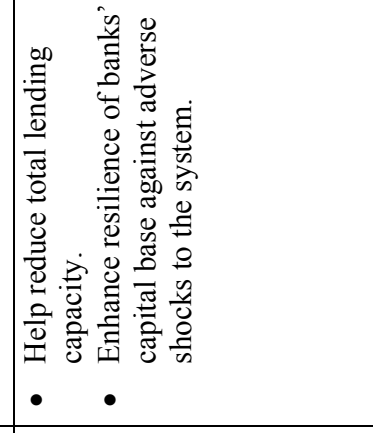 & 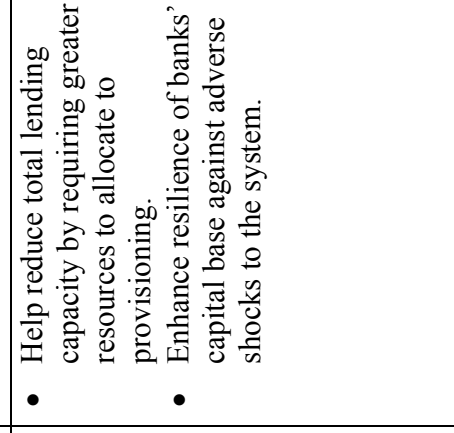 & 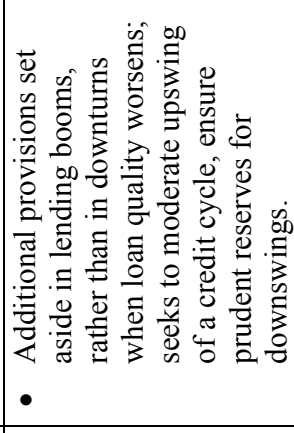 \\
\hline & & 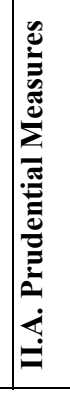 & 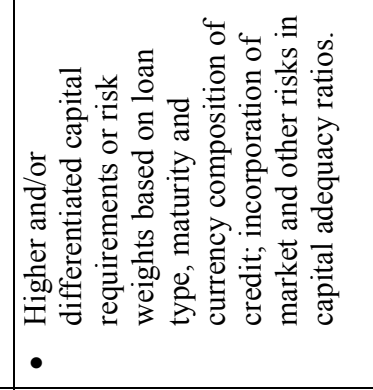 & 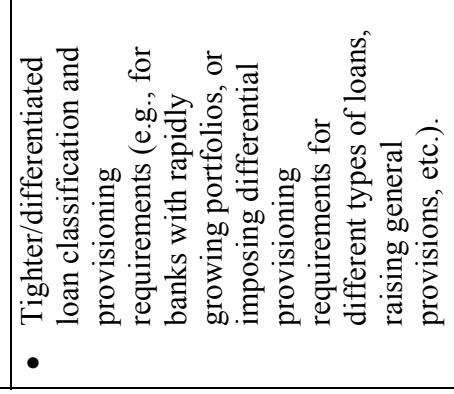 & 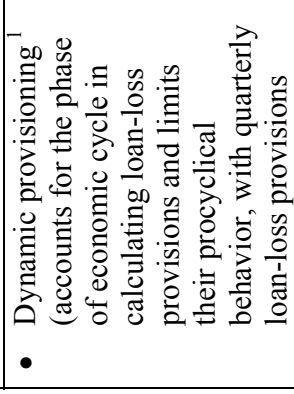 \\
\hline
\end{tabular}




\begin{tabular}{|c|c|c|c|c|c|c|}
\hline 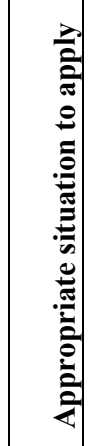 & & 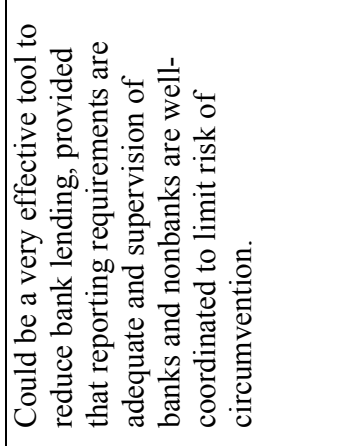 & 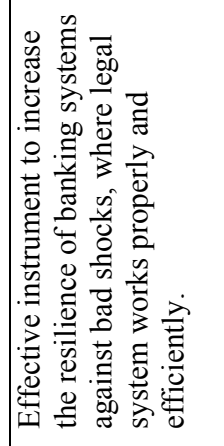 & 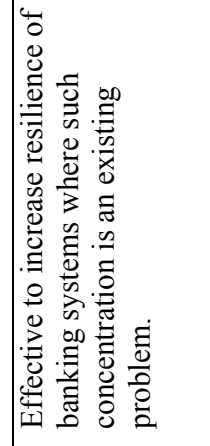 & 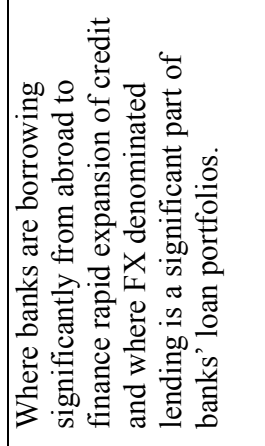 & 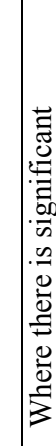 \\
\hline 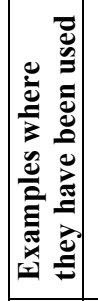 & & 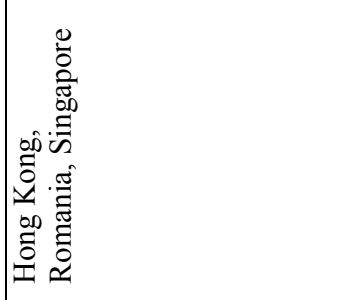 & 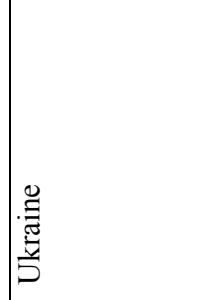 & 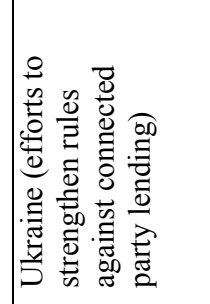 & 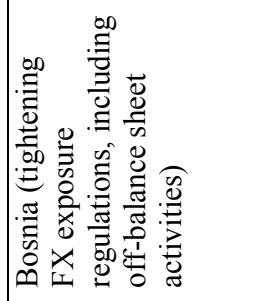 & \\
\hline 号 & 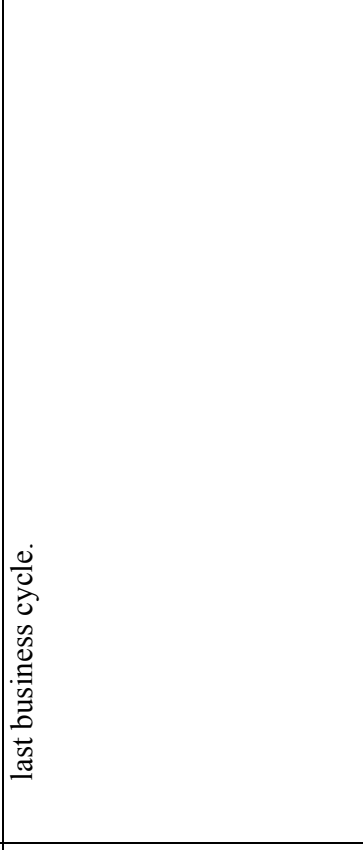 & 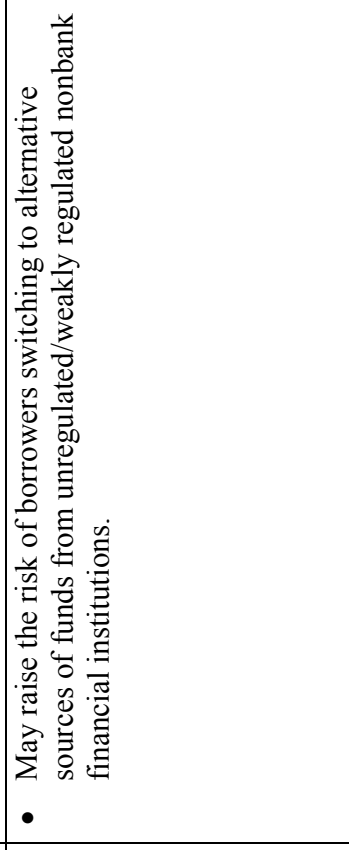 & 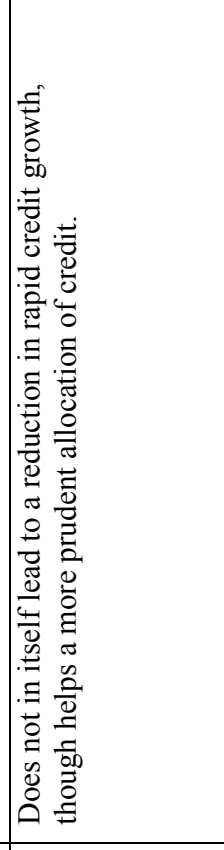 & 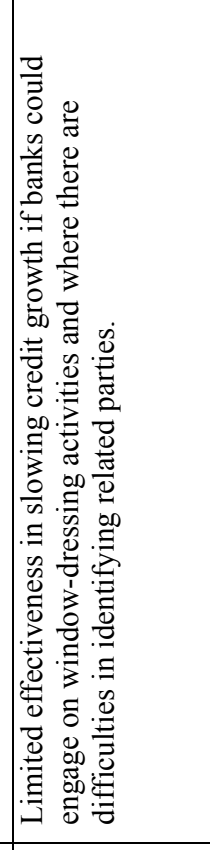 & 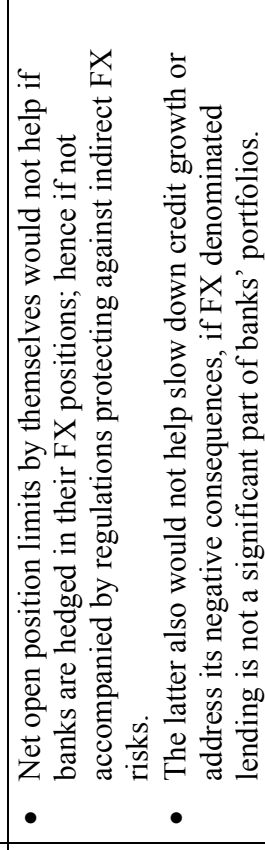 & \\
\hline . & 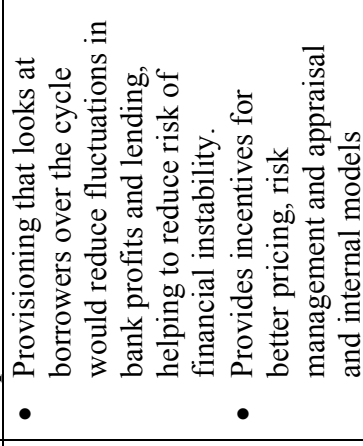 & 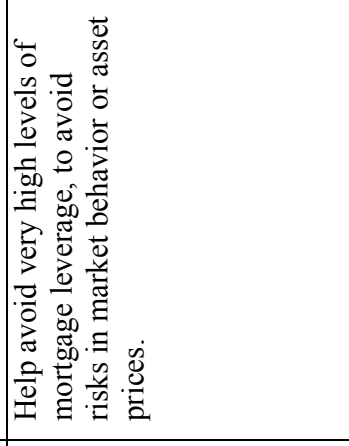 & 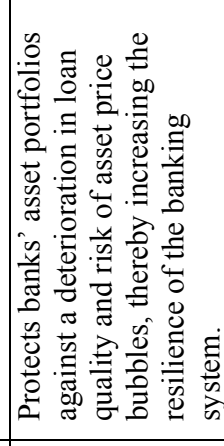 & 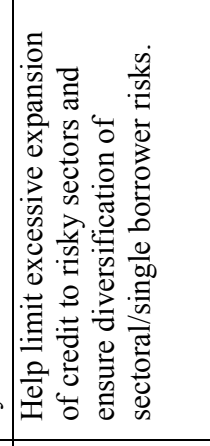 & 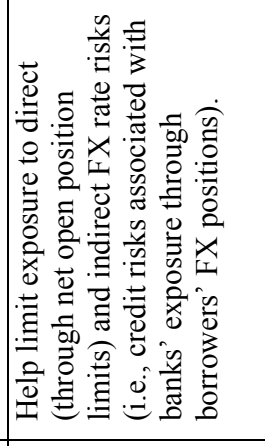 & 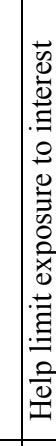 \\
\hline 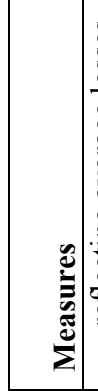 & 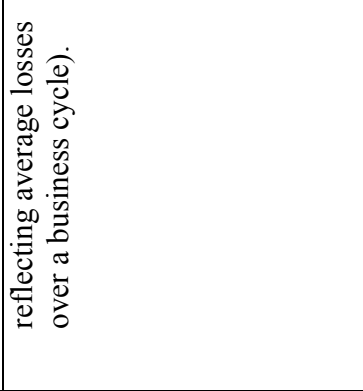 & 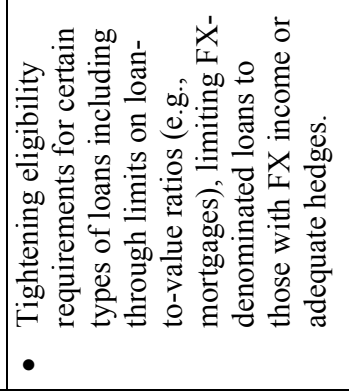 & 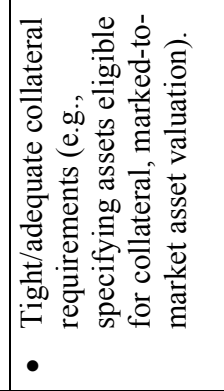 & 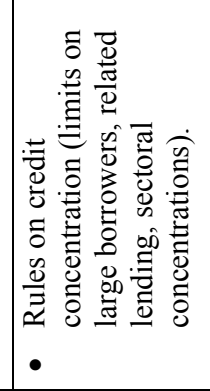 & 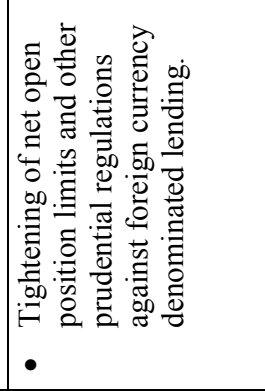 & 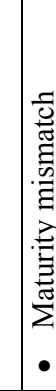 \\
\hline
\end{tabular}




\begin{tabular}{|c|c|c|c|c|c|c|}
\hline & 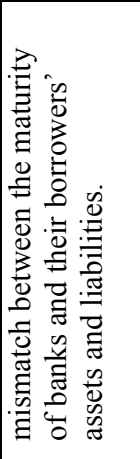 & 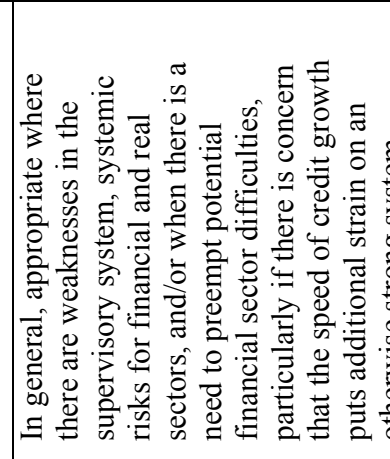 & 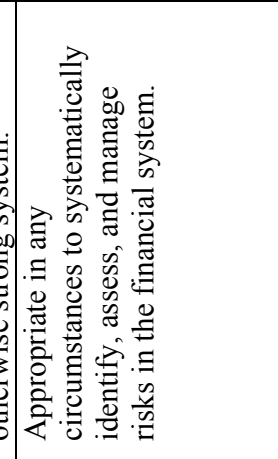 & 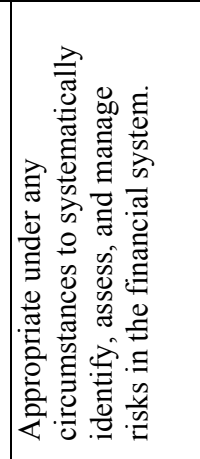 & 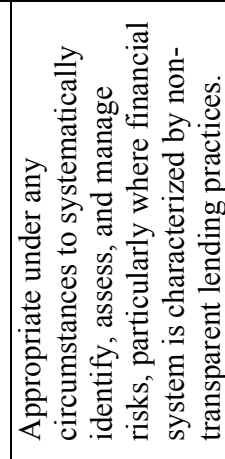 & 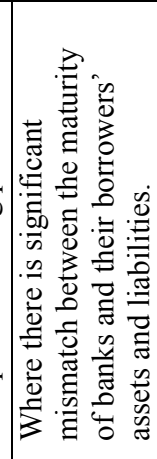 \\
\hline & & & & 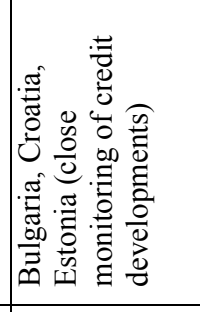 & 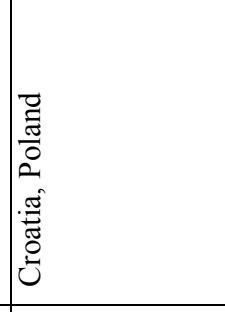 & \\
\hline & & 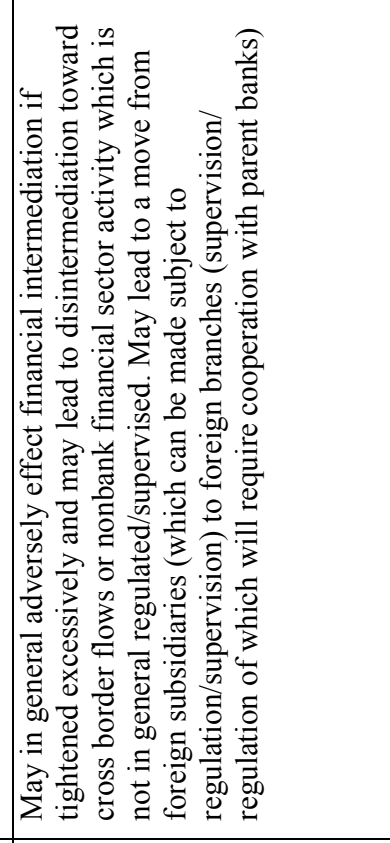 & 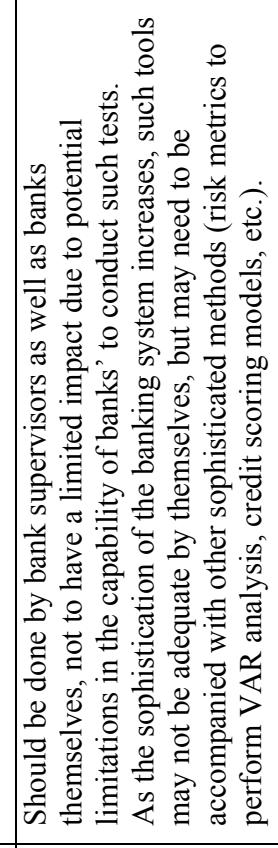 & 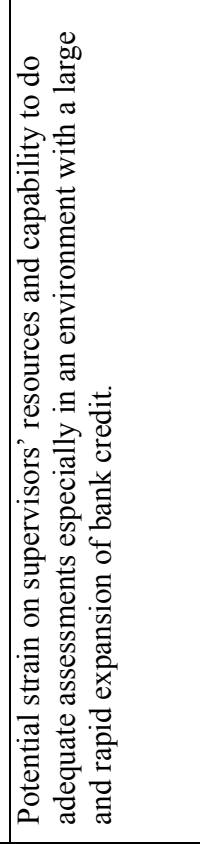 & 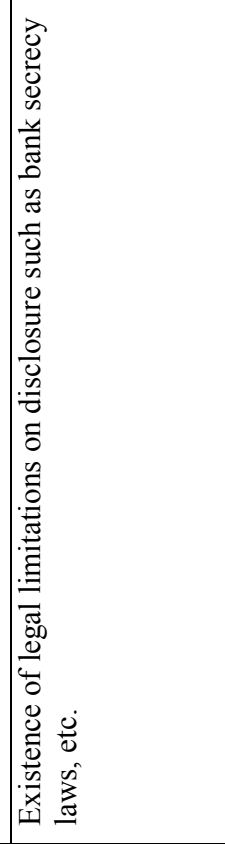 & 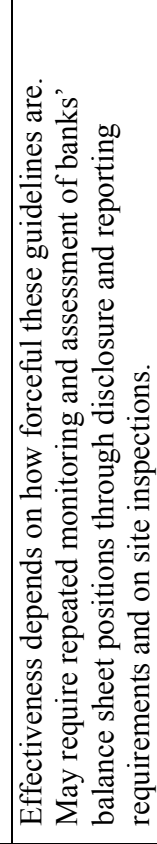 \\
\hline & 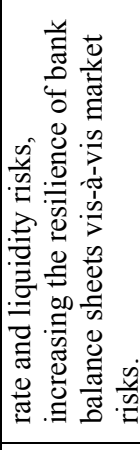 & & 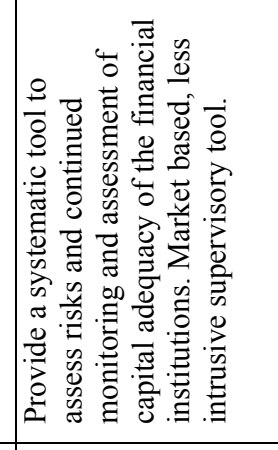 & 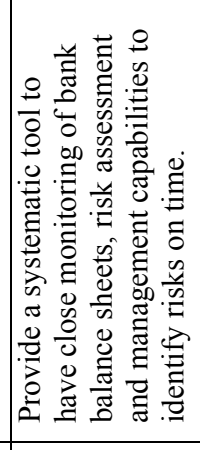 & 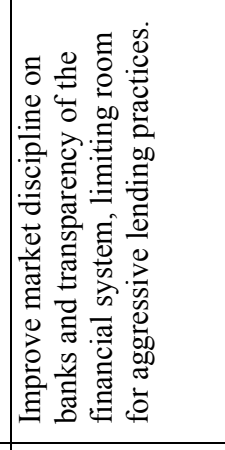 & 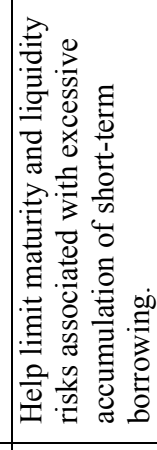 \\
\hline & & 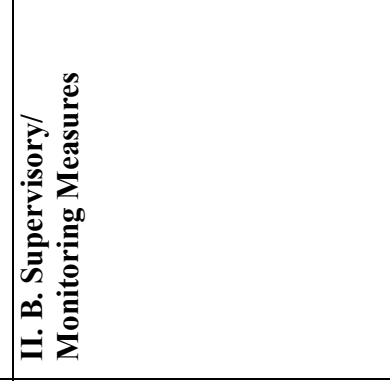 & 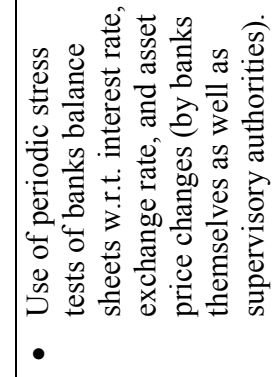 & 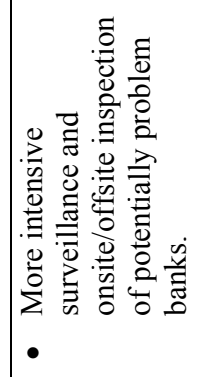 & 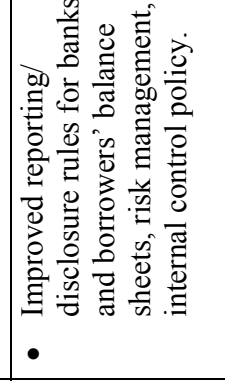 & 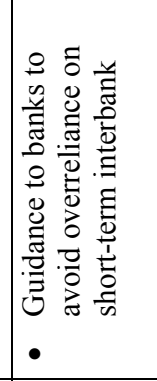 \\
\hline
\end{tabular}




\begin{tabular}{|c|c|c|c|c|c|c|}
\hline 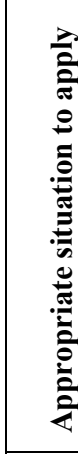 & 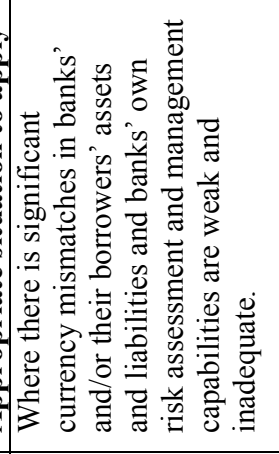 & 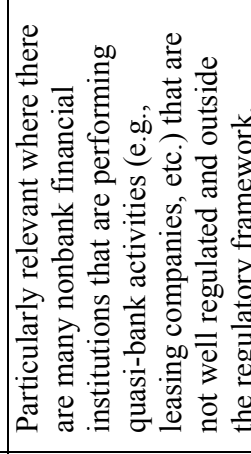 & 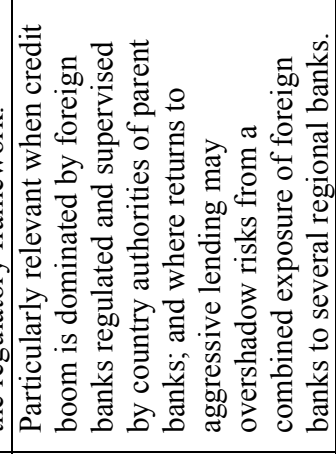 & & 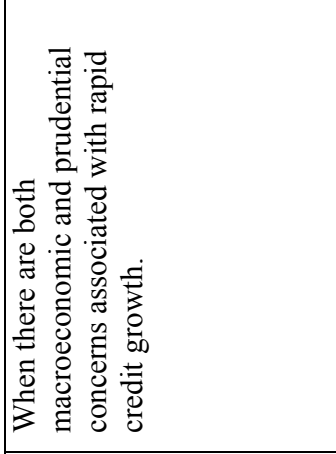 & 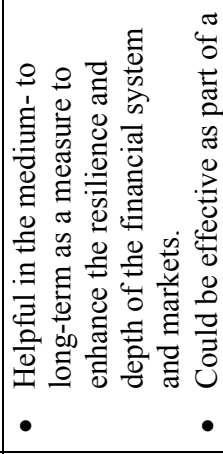 \\
\hline 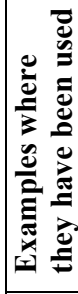 & 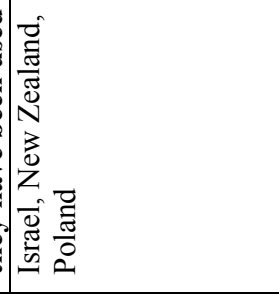 & 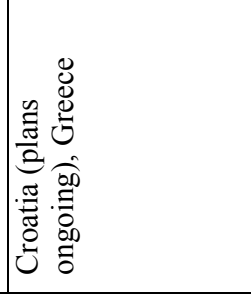 & 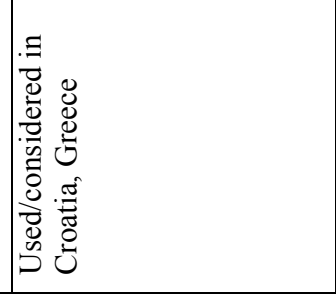 & & & 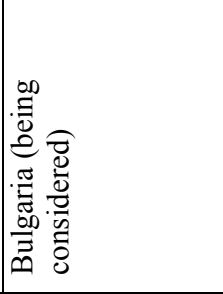 \\
\hline 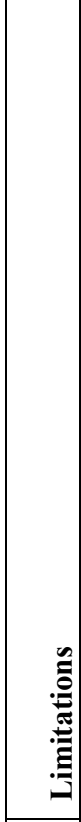 & $\stackrel{0}{0}$ & 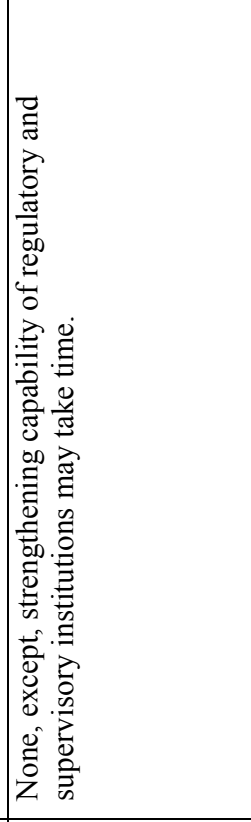 & & & 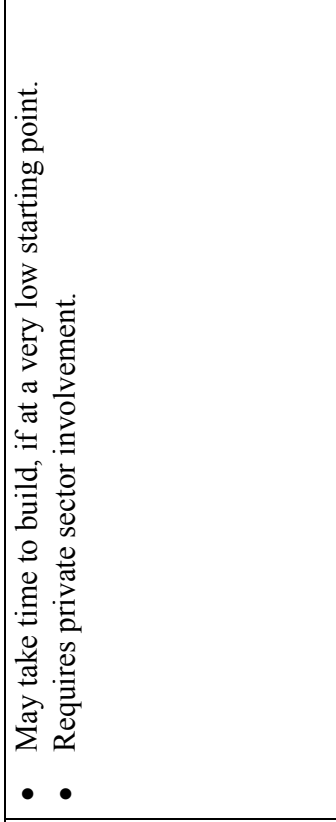 & 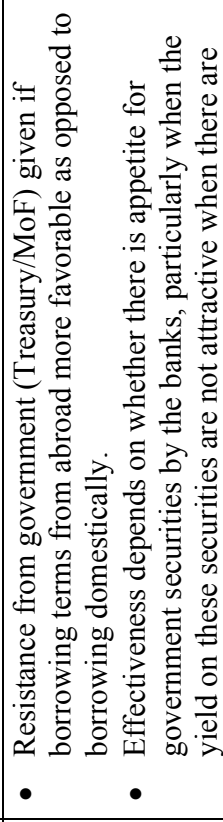 \\
\hline 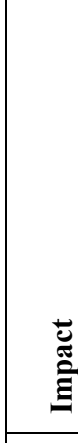 & 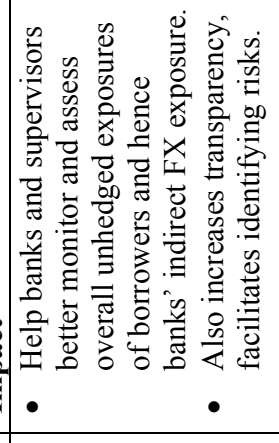 & 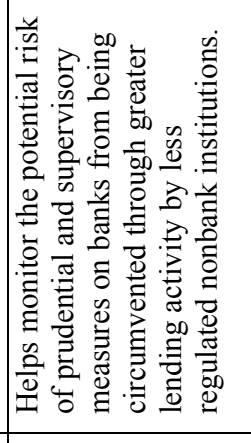 & 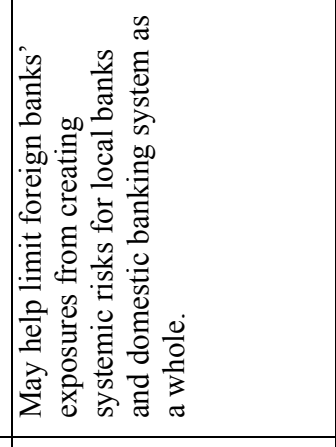 & 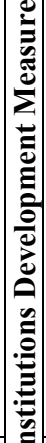 & 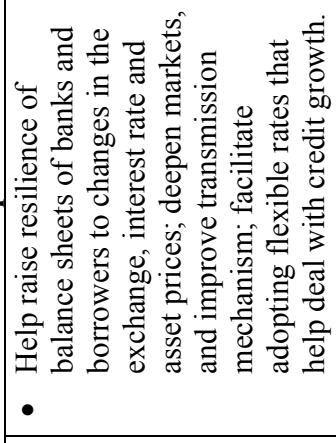 & 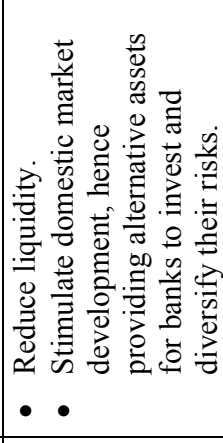 \\
\hline 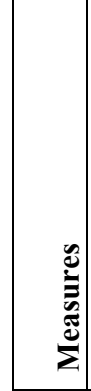 & 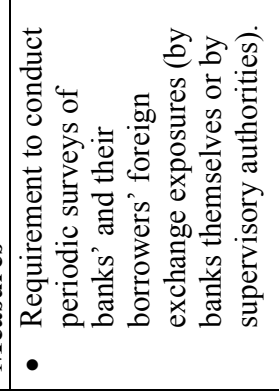 & 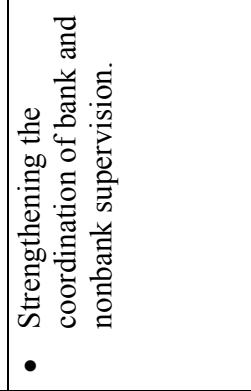 & 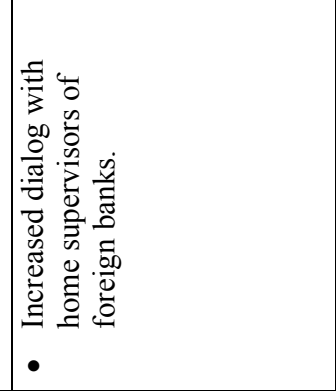 & 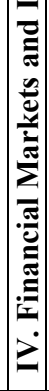 & 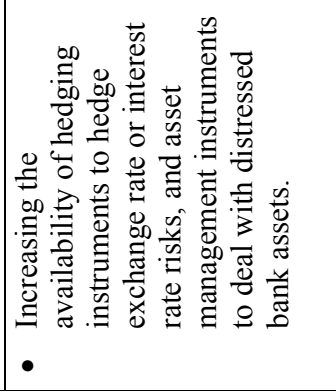 & 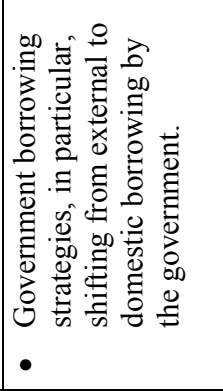 \\
\hline
\end{tabular}




\begin{tabular}{|c|c|c|c|c|c|c|c|}
\hline 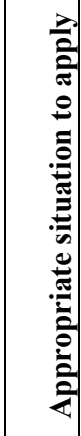 & 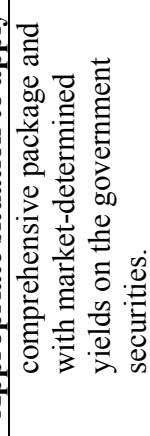 & 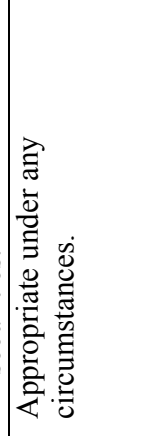 & 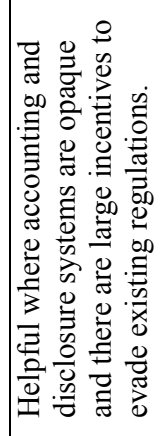 & 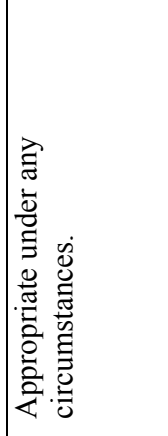 & & 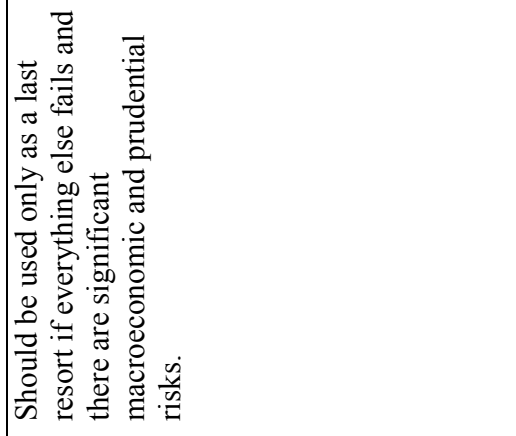 & 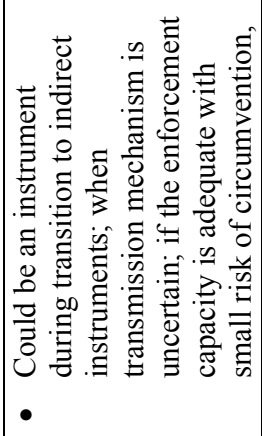 \\
\hline 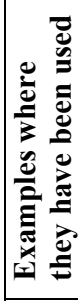 & & 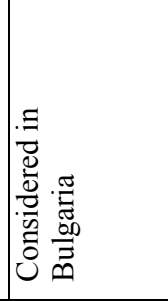 & 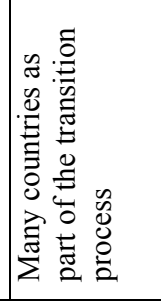 & 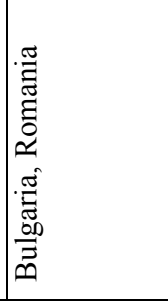 & & 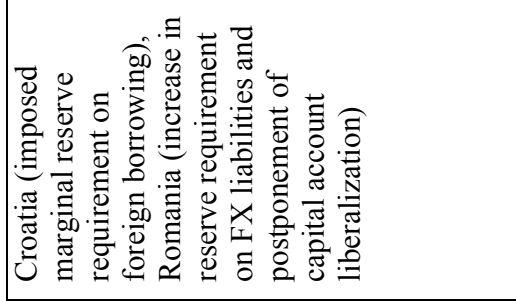 & 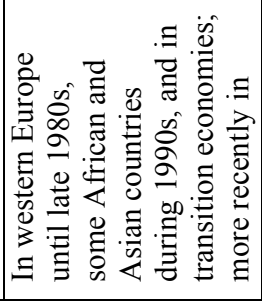 \\
\hline 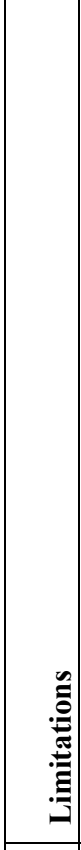 & 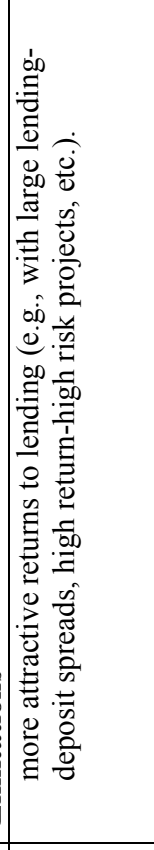 & 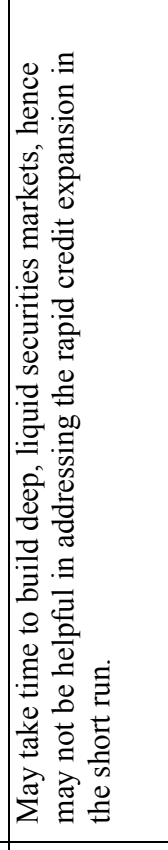 & 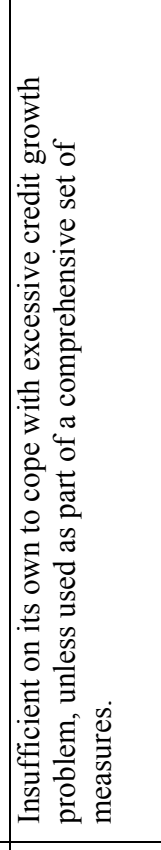 & है & & 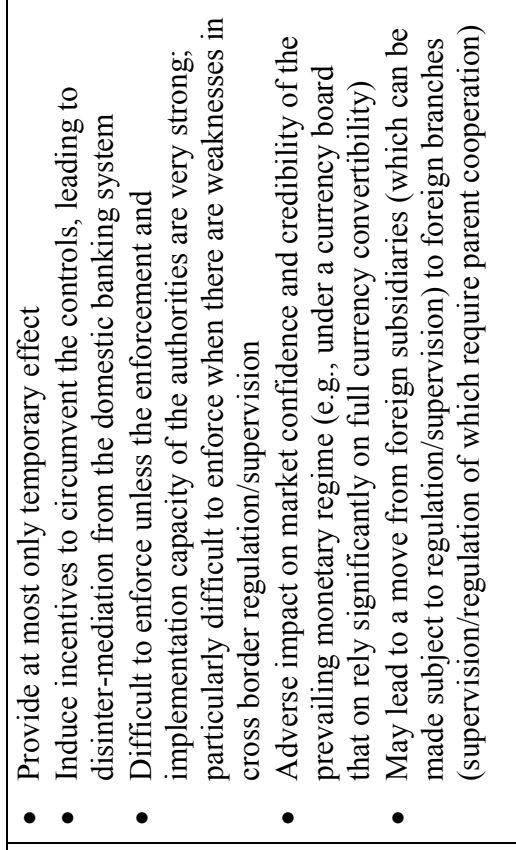 & 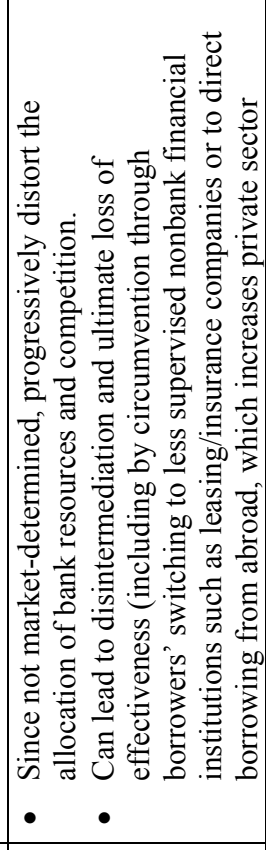 \\
\hline $\begin{array}{l}\overline{\tilde{U}} \\
\overline{\tilde{w}} \\
\bar{\Xi}\end{array}$ & & 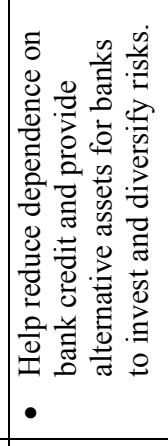 & 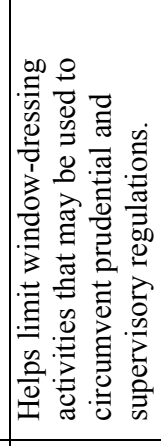 & 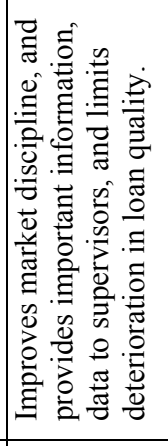 & & 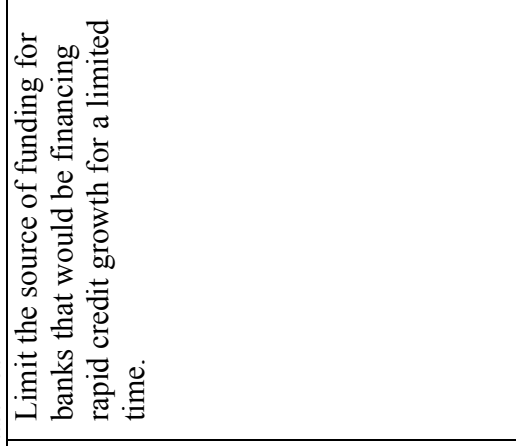 & 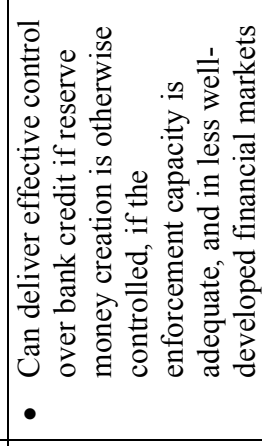 \\
\hline$\Sigma$ & & 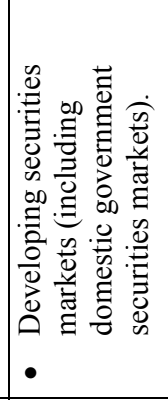 & 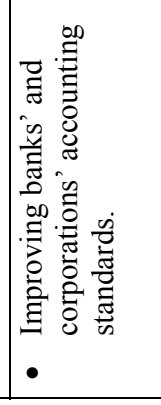 & 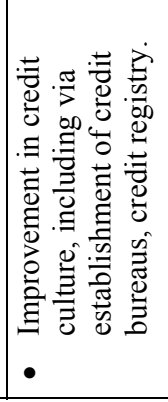 & 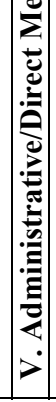 & 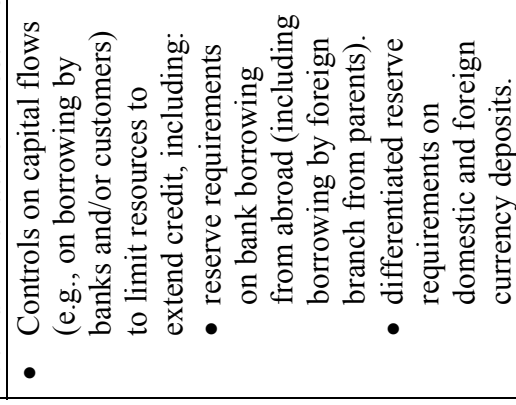 & 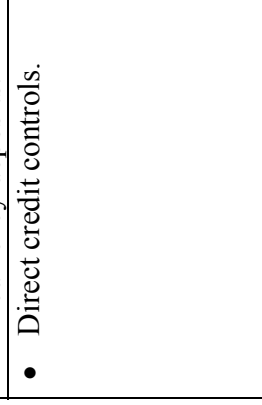 \\
\hline
\end{tabular}




\begin{tabular}{|c|c|c|c|c|c|c|}
\hline 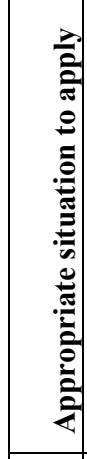 & 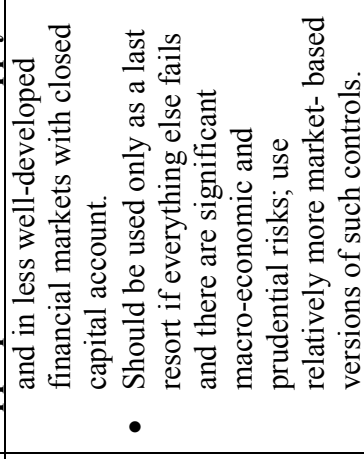 & & & 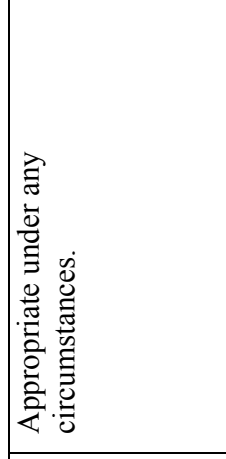 & 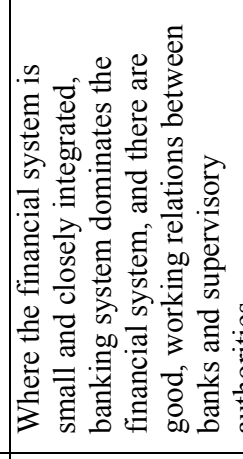 & 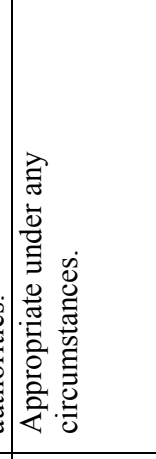 \\
\hline 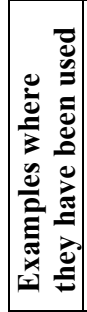 & 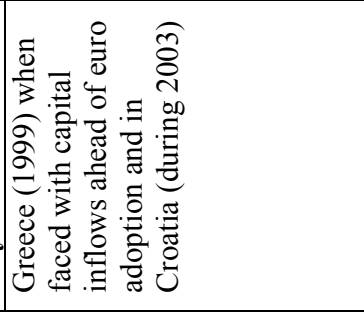 & 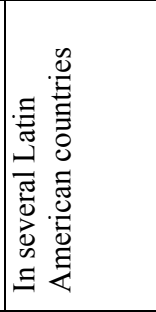 & & 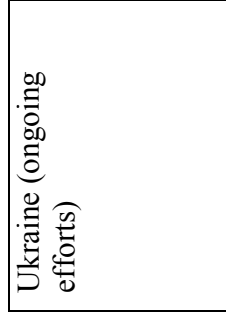 & 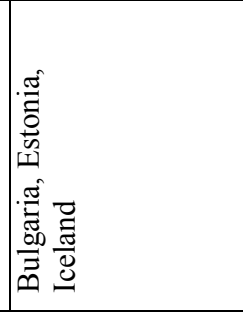 & 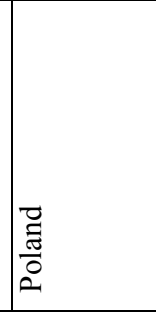 \\
\hline 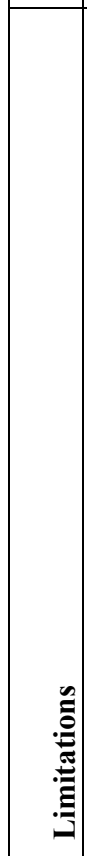 & 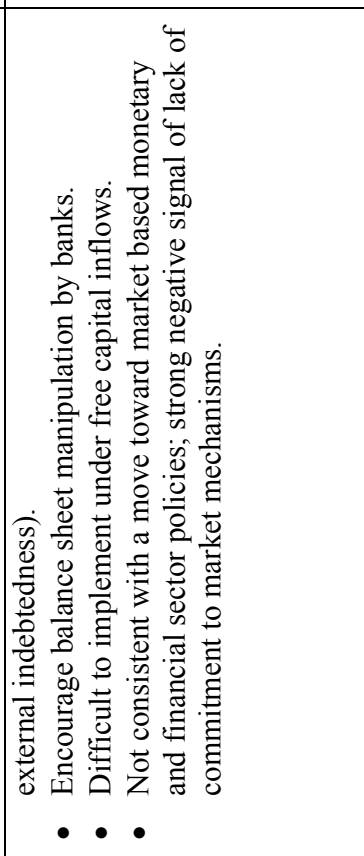 & 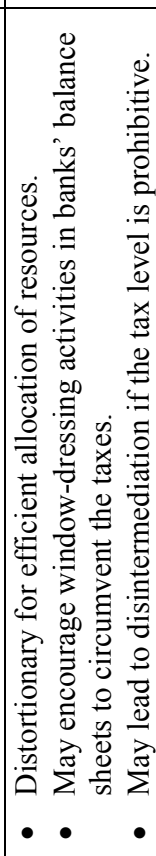 & & 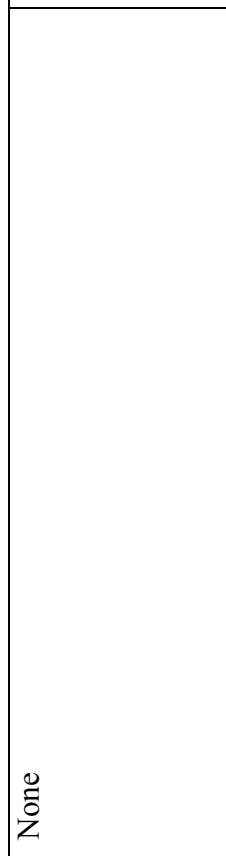 & 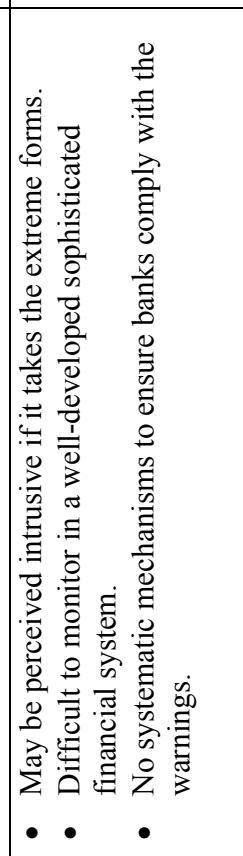 & 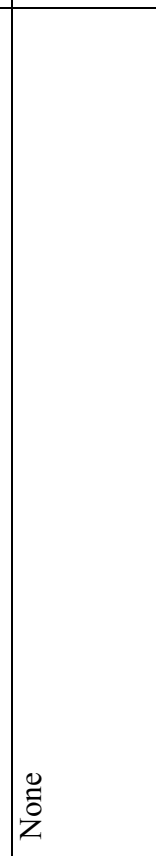 \\
\hline $\begin{array}{l}\overline{\tilde{w}} \\
\bar{w} \\
\bar{\Xi}\end{array}$ & 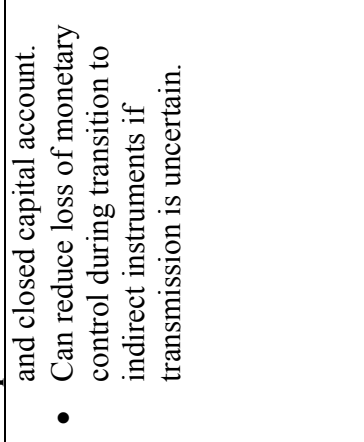 & 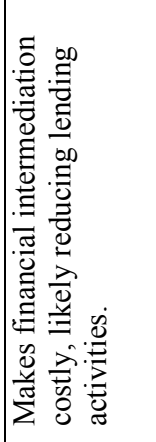 & 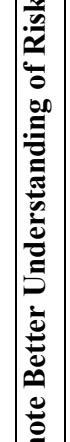 & 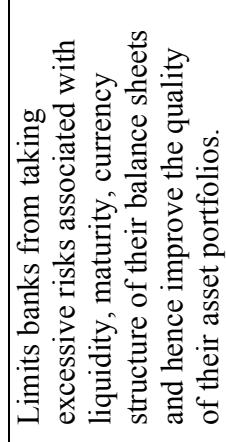 & 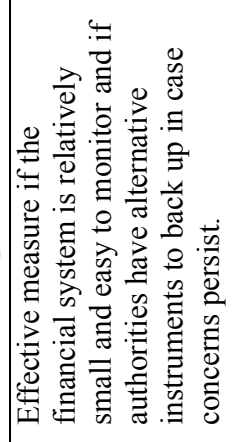 & 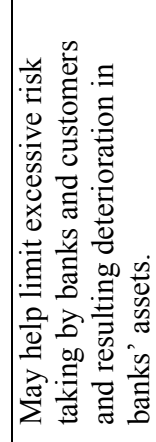 \\
\hline$\sum^{\frac{\pi}{2}}$ & & 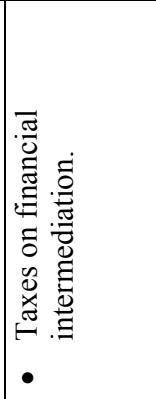 & 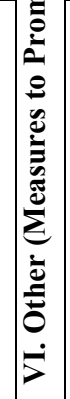 & 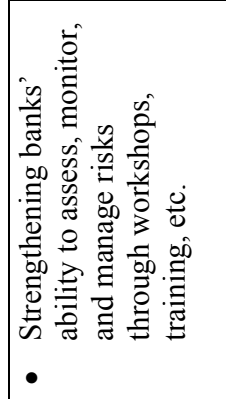 & 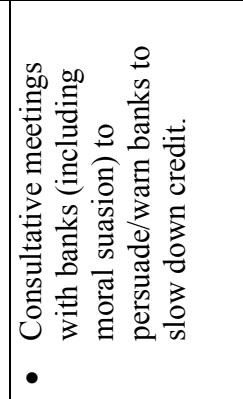 & 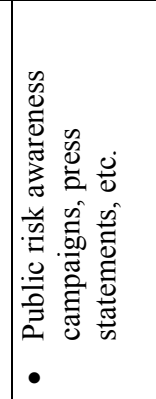 \\
\hline
\end{tabular}

을

E.

荧总

돌

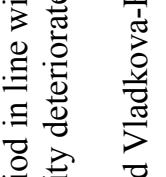

远

司芯

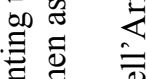

言

导 昰

ङ

.$\Xi 0$

플 ڤ

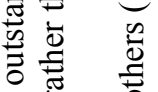

氙

के

品.

잉

可

ष

원

割

응

을

ㄹ.

可

흔 흥

照

흘 훌

पर हो प्र

施部

论占造

ज्ञ

on. 흘 च

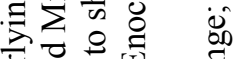

密

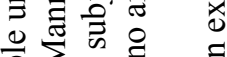

응 $\sum_{n}$

르의

可 娄

可 8

틍

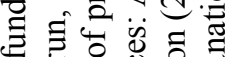

일 


\section{Measures Used to Deal with Credit Growth in Selected European Countries}

\begin{tabular}{|c|c|c|}
\hline Country & Measures with potential impact on credit growth & Impact to date \\
\hline Bosnia & $\begin{array}{l}\text { Reform of reserve requirements in mid- and end-2003 (including foreign } \\
\text { currency in the base, excluding vault cash from assets eligible to meet } \\
\text { reserve requirements) to withdraw bank liquidity, and a reduction in the } \\
\text { remuneration of excess reserves at the central bank (twice); } \\
\text { New tighter bank core capital requirements, tighter foreign exposure } \\
\text { regulations (including off-balance sheet activities) and strengthened } \\
\text { application of bank liquidity regulations. }\end{array}$ & $\begin{array}{l}\text { The credit boom that followed the surge in bank } \\
\text { deposits since } 2001 \text { has eased somewhat (as of } \\
\text { early 2004), in the wake of the mid- } 2003 \\
\text { monetary and regulatory tightening that has been } \\
\text { stimulated by macroeconomic concerns. Banks } \\
\text { seemed to comply with these measures and } \\
\text { overall credit to private sector slowed down } \\
\text { (from about } 26 \% \text { in } 2002 \text { to } 21 \% \text { in November } \\
2003 \text { as a whole, although credit to enterprises } \\
\text { accelerated). The regulatory reforms also raised } \\
\text { banks' demand for excess central bank deposits, } \\
\text { stemming the growth of credit. }\end{array}$ \\
\hline Bulgaria & $\begin{array}{l}\text { - As a first phase in their strategy to deal with credit growth, the } \\
\text { authorities also used suasion through public statements and meetings } \\
\text { with banks, especially those with aggressive lending behavior. More } \\
\text { recently, the NBB embarked on a series of meetings with CEOs of } \\
\text { commercial banks to discuss the ongoing credit expansion and possible } \\
\text { measures to dampen credit. } \\
\text { - Since mid-2003, the BNB has been implementing a set of sequential } \\
\text { measures to strengthen bank supervision, including tightening of loan } \\
\text { classification and provisioning requirements; increasing the frequency } \\
\text { and focus of onsite inspections, and restricting conditions under which } \\
\text { current profits can be included in regulatory capital. } \\
\text { On the fiscal side, the authorities tightened their fiscal stance, in } \\
\text { response to the widening of the current account deficit. } \\
\text { On the monetary side, given the limited options under a currency board, } \\
\text { the authorities try to reduce banking system liquidity by tightening } \\
\text { reserve requirements (by reducing the share of vault cash in eligible } \\
\text { assets and broadening the liability base subject to RR by including } \\
\text { deposits and securities with longer term maturity and repos); considered } \\
\text { also to introduce a liquid asset requirement as a further measure to } \\
\text { reduce bank liquidity to limit banks' capacity to lend. } \\
\text { To reduce information asymmetries and their adverse impact, the } \\
\text { authorities also aim to strengthen information on retail lending } \\
\text { conditions (e.g., overall indebtedness of particular households). } \\
\text { Consistent with its overall strategy to raise the share of domestic debt in } \\
\text { total debt, as well as to limit credit growth by reducing bank liquidity } \\
\text { while stimulating domestic market development, the government plans } \\
\text { to shift from external borrowing to domestic borrowing (which is } \\
\text { envisaged to be mostly absorbed by banks). } \\
\text { Introduced marginal reserve requirements for banks exceeding certain } \\
\text { rate of credit growth (Feb 2005). }\end{array}$ & $\begin{array}{l}\text { Domestic credit growth has remained strong (as } \\
\text { of late 2004). Financed by a sharp rise in } \\
\text { deposits (in particular FX deposits) and in bank } \\
\text { foreign liabilities, } 12 \text {-month growth in claims to } \\
\text { the non-government sector rose to } 521 / 2 \% \text { in } \\
\text { July, after having fallen to } 47.8 \% \text { in June. } \\
\text { Financing of the credit expansion relied more on } \\
\text { the rapid increase in banks' foreign liabilities } \\
\text { than drawing down their foreign assets which } \\
\text { was the case before. The share of corporate credit } \\
\text { continued to fall gradually, but still remained at } \\
\text { about two-thirds of the total; corporate credit } \\
\text { rose nearly } 42 \% \text {, while consumer credit by } \\
76.3 \% \text {, down from the January-July average of } \\
80.7 \text { percent. } \\
\text { The anticipated impact of the various credit and } \\
\text { prudential measures has been reduced by rapid } \\
\text { deposit growth (much of it from non-residents) } \\
\text { and greater-than-expected bank foreign } \\
\text { borrowing, with banks being able to obtain loans } \\
\text { from abroad much easier than assumed (mostly } \\
\text { from parent banks to their Bulgarian subsidiaries, } \\
\text { given the continued high profits Bulgarian banks } \\
\text { are generating, the investment grade rating } \\
\text { recently given to Bulgarian sovereign debt, and } \\
\text { rising confidence in timely EU accession). }\end{array}$ \\
\hline $\mathbf{C r}$ & 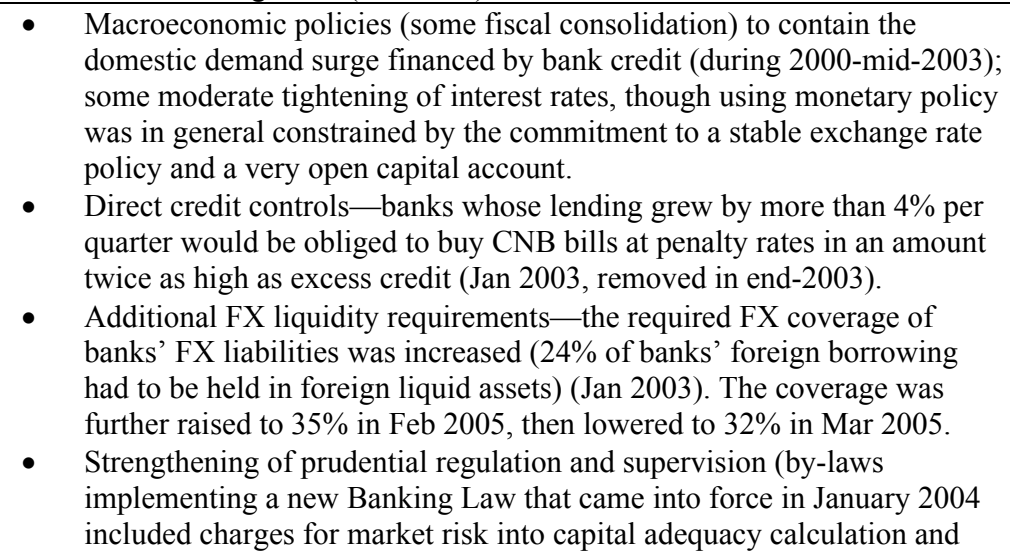 & $\begin{array}{l}\text { - Macroeconomic policies did not manage to } \\
\text { contain the surge in domestic demand, as fiscal } \\
\text { consolidation was not sufficient to offset the } \\
\text { growth in private consumption and investment; } \\
\text { current account deficit rose sharply (above } 8 \% \text { of } \\
\text { GDP). But credit boom unwound in } 2002 \text { and } \\
\text { early } 2003 \text {, likely reflecting debt carrying } \\
\text { constraints as well as credit controls imposed by } \\
\text { CNB, although lack of data precludes a full } \\
\text { assessment of trends. } \\
\text { Direct credit controls were not successful in } \\
\text { controlling aggregate demand or current account } \\
\text { deficit: bank credit decelerated significantly } \\
\text { since mid-2003), possibly affecting spending by } \\
\text { households that do not have easy access to }\end{array}$ \\
\hline
\end{tabular}




\begin{tabular}{|c|c|c|}
\hline Country & Measures with potential impact on credit growth & Impact to date \\
\hline & $\begin{array}{l}\text { increased provisioning for banks with rapidly growing portfolios. The } \\
\text { CNB's banking supervision department was reorganized to operate more } \\
\text { on risk basis, and its staffing was strengthened. } \\
\text { CNB introduced regulations requiring rapidly growing banks to meet } \\
\text { even higher capital adequacy standards or be subject to mandatory } \\
\text { retention of a portion of profits (early 2004). } \\
\text { Attempts to introduce counterparty exposure reporting systems, but with } \\
\text { limited success due to weak reliability of data from the corporate sector. } \\
\text { Introduction of marginal reserve requirement on foreign borrowing (July } \\
\text { 1, 2004) to reduce external vulnerability (from 11\% of foreign borrowing } \\
\text { to } 35 \% \text { of their new foreign borrowing). } \\
\text { The authorities saw introduction of (price-based) capital controls as last- } \\
\text { resort policy option, in case of unexpected capital inflows that may } \\
\text { threaten macroeconomic stability. } \\
\text { The authorities appointed a working group (Oct 2004) to unify } \\
\text { supervision of nonbank institutions to cover supervision gaps (due to the } \\
\text { rapid expansion of unregulated and unsupervised leasing companies and } \\
\text { significant risk transfer from banks to insurance companies with limited } \\
\text { risk management capacity and supervisory capacity in the insurance } \\
\text { sector). The group is actively planning to implement the reform. } \\
\text { Recent agreement with the Fund on the need to closely monitor } \\
\text { customers' FX risk during onsite inspections (including asking banks to } \\
\text { inquire and report on the largest customers' FX exposure). }\end{array}$ & $\begin{array}{l}\text { foreign borrowing, but corporates moved } \\
\text { significantly out of borrowing from domestic to } \\
\text { foreign banks (local banks typically directed } \\
\text { most of their best corporate customers to their } \\
\text { parent banks abroad) and used leasing and other } \\
\text { forms of financing provided by unsupervised and } \\
\text { unregulated leasing companies. Foreign debt rose } \\
\text { strongly in } 2003 \text { with borrowing by banks and } \\
\text { nonfinancial enterprises. } \\
\text { The limits hence also had a negative impact on } \\
\text { the soundness of the financial sector. Anecdotal } \\
\text { evidence suggests that insurance companies have } \\
\text { taken on a substantial part of the credit risks } \\
\text { associated with banks' retail portfolios, which is } \\
\text { a concern given the limited risk management and } \\
\text { supervisory capacity in the insurance sector. Also } \\
\text { transparency of monetary and banking statistics } \\
\text { deteriorated as banks engaged in some activities } \\
\text { designed mainly to circumvent the limits, such as } \\
\text { asset swaps, collateralization, and accelerated } \\
\text { NPLs write-offs. } \\
\text { Private sector borrowing in FX remains a } \\
\text { concern. Banks are vulnerable to indirect FX risk } \\
\text { (credit risk due to currency mismatch between } \\
\text { assets and liabilities of some clients) (about } 78 \% \\
\text { of bank loans are denominated in or linked to FX } \\
\text { and a significant share of those loans (about } \\
60 \% \text { ) is extended to borrowers with kuna- } \\
\text { denominated sources of income and often with } \\
\text { limited access to hedging instruments). }\end{array}$ \\
\hline Estonia & $\begin{array}{l}\text { The authorities recently reduced borrowing incentives by limiting } \\
\text { mortgage interest deductibility to address the rise in households' real } \\
\text { estate related borrowing, with plans for further reduction. } \\
\text { Moral suasion: the central bank and the financial supervisory authority } \\
\text { repeatedly discussed and stressed with banks the need for continuing } \\
\text { conservative lending practices. } \\
\text { - Close monitoring of developments in credit. }\end{array}$ & $\begin{array}{l}\text { Domestic credit growth has remained robust to } \\
\text { date (Oct 2004), financed increasingly by bank } \\
\text { borrowing from abroad, mainly from foreign } \\
\text { parent banks. Bank credit to household sector } \\
\text { (mainly to acquire real estate) at } 50 \% \text { y/y in } \\
\text { Q104 and credit to enterprises at } 30 \% \text { in } \mathrm{H} 104 \text {. } \\
\text { Around } 65 \% \text { of household loans and } 78 \% \text { of } \\
\text { enterprise credits are in FX ( } 95 \% \text { in euros). }\end{array}$ \\
\hline Greece & $\begin{array}{l}\text { - In response to an acceleration of credit growth (in particular credit to } \\
\text { households expanded by around 30\%), stimulated by the favorable } \\
\text { economic environment ahead of EU accession, Greece imposed credit } \\
\text { controls in the form of non-remunerated deposits for an amount } \\
\text { equivalent to the growth of credit above specified rates (mid-April } \\
\text { 1999); at end-July 1999, in the face of still rapid consumer lending, } \\
\text { penalty for excess lending in this category was doubled. Non- } \\
\text { remunerated deposits were extended through the end of March } 2000 \text {. } \\
\text { Restrictions were lifted in April } 2000 \text {. } \\
\text { Additional measures were taken to prevent a surge in liquidity when } \\
\text { reserve requirements were reduced to the euro area's } 2 \% \text {, with freed-up } \\
\text { reserves converted into blocked interest bearing deposits at the central } \\
\text { bank, to be gradually released until end-2001. } \\
\text { Attention was then given more to greater monitoring of qualitative } \\
\text { aspects of banks' activities, notably their credit management processes } \\
\text { through stress testing and scenario analysis, to enhancing market } \\
\text { discipline through greater public disclosure, improvement of } \\
\text { coordination between supervisory agencies, and strengthening the } \\
\text { independence of the supervisors. }\end{array}$ & $\begin{array}{l}\text { - Credit growth has remained robust following the } \\
\text { April } 1999 \text { measures, which necessitated further } \\
\text { tightening several times until April 2000. In } \\
\text { general the extent of slowdown in bank credit } \\
\text { was limited by the increasingly accommodative } \\
\text { monetary conditions in the run-up to the } \\
\text { monetary union with a general decline in interest } \\
\text { rates, easing of reserve requirements, lifting of } \\
\text { credit restrictions in April } 2000 \text { and integration } \\
\text { into the interbank euro market. }\end{array}$ \\
\hline Ic & $\begin{array}{l}\text { In response to a rapid rise of credit growth by deposit money banks } \\
\text { during } 1998-99 \text {, which was being increasingly financed by foreign }\end{array}$ & $\begin{array}{l}\text { - As a result of the liquidity requirements, the } \\
\text { commercial and savings banks' liquidity }\end{array}$ \\
\hline
\end{tabular}




\begin{tabular}{|c|c|c|}
\hline Country & Measures with potential impact on credit growth & Impact to date \\
\hline & $\begin{array}{l}\text { borrowing by banks (with high proportion being short-term), the central } \\
\text { bank took a few measures: } \\
\text { Moral suasion: it issued cautionary remarks to parties capable of } \\
\text { influencing this development (management of banks and government } \\
\text { authorities as the main owners of some of the players); } \\
\text { Tightening of interest rates: the central bank raised its key policy rate } \\
\text { three times during 1999; } \\
\text { It set liquidity requirement ratios for credit institutions (February 1999) } \\
\text { to counter the deteriorating liquidity position of credit institutions and } \\
\text { their increasing use of short-term foreign capital. }\end{array}$ & $\begin{array}{l}\text { positions improved significantly and the share of } \\
\text { short-term foreign borrowing in liabilities were } \\
\text { reduced. } \\
\text { The real growth of bank lending also slowed } \\
\text { down somewhat (from } 30 \% \text { in } 1998 \text { to } 15 \% \text { until } \\
\text { about early 2000), but it picked up again } \\
\text { subsequently and remained at high levels during } \\
\text { 2000. Whether the initial decline could be } \\
\text { entirely attributed to the new liquidity rules was } \\
\text { also uncertain, since the decline could also reflect } \\
\text { the warnings and the impact of interest rate rises. } \\
\text { The liquidity rules, along with other factors, also } \\
\text { led to some reduction in trading in bank and } \\
\text { treasury bills. }\end{array}$ \\
\hline Latvia & $\begin{array}{l}\text { - Raised interest rates - refinancing rate (March 2004), and increased } \\
\text { reserve requirements (July 2004) partially reversing an earlier decline to } \\
\text { bring them in line with European Central Bank (ECB) requirements to } \\
\text { stem private sector credit growth and inflation. }\end{array}$ & $\begin{array}{l}\text { - So far the measures had limited effect, since } \\
\text { banks' funding is mainly derived from abroad } \\
\text { (Eurobond floatation and credit from parent } \\
\text { banks) and domestic loans are extended mainly } \\
\text { in foreign currencies. } \\
\text { - Higher interest rates likely attracted additional } \\
\text { capital inflows. }\end{array}$ \\
\hline Moldova & $\begin{array}{l}\text { - Responding to rapid bank credit growth over the past four years, the } \\
\text { National Bank of Moldova (NBM) gradually implemented a system } \\
\text { where required reserves for FX deposits are held in FX (since July 04). } \\
\text { The NBM required banks to have separate risk management units to } \\
\text { identify and reduce specific risk exposures. The assessment of credit risk } \\
\text { is generally made on a borrower-by-borrower basis, and the banks share } \\
\text { information on problem borrowers on an informal basis, in the absence } \\
\text { of a credit registry. }\end{array}$ & $\begin{array}{l}\text { - Credit growth decelerated somewhat in } 2004 \text { but } \\
\text { still remained strong. }\end{array}$ \\
\hline Poland & $\begin{array}{l}\text { - In response to increased foreign currency lending by banks from mid- } \\
\text { 2000, the supervisory authorities adopted a new capital adequacy } \\
\text { regulation (in line with EU standards) that expanded the existing FX } \\
\text { regulation to cover other risks (market, interest rate, commodity price } \\
\text { and equity or debt instruments price risks), and required banks to } \\
\text { increase capital to incorporate the aforementioned risks (this is in } \\
\text { addition to the regulatory capital for credit risk). The previous limits on } \\
\text { FX open positions were hence replaced with capital charges, implying } \\
\text { higher capital for higher FX risks. } \\
\text { Periodic surveys of banks' FX exposure by supervisors to obtain specific } \\
\text { information on banks' foreign currency lending, including borrowers' } \\
\text { appetite for foreign currency loans, percentage of customers hedging } \\
\text { their exchange rate risks, the form of hedging offered to customers, } \\
\text { foreign currency loans protected by guarantees, costs for hedging loans } \\
\text { as ratio to the loan, loan classification and provisions made, foreign } \\
\text { exchange positions, by currency, receipts/costs of foreign exchange } \\
\text { transactions, extent of engagement in arbitrage transactions. surveys } \\
\text { followed up by action on procedures and banks stress tests. } \\
\text { Close monitoring of banks' exposure to FX risk and quality of FX risk } \\
\text { management, internal controls. The authorities developed a credit } \\
\text { information database and formed a unit to monitor vulnerabilities from } \\
\text { credit risk associated with FX denominated lending. } \\
\text { Some form of moral suasion: From 2001, supervisors' warning of banks } \\
\text { and written guidance from head of supervision, and press coverage of } \\
\text { risks to households. }\end{array}$ & $\begin{array}{l}\text { The rapid increase in FX-denominated credit } \\
\text { since mid-2000 reversed in late } 2002 \text { (at an } \\
\text { average of around } 26 \% \text { of total loans during } \\
2000-2003 \text { ). The depreciation of the zloty against } \\
\text { the euro and the narrowing of the spreads } \\
\text { between zloty and foreign interest rates were also } \\
\text { believed to have reduced foreign currency } \\
\text { borrowing. The rapid growth of FX-denominated } \\
\text { housing loans slowed significantly in the last } \\
\text { quarter of } 2003 \text { as zloty interest rates declined } \\
\text { and households became more careful about } \\
\text { unhedged borrowing. Nonetheless, about half of } \\
\text { the outstanding stock of housing loans was still } \\
\text { FX denominated or -indexed. }\end{array}$ \\
\hline
\end{tabular}




\begin{tabular}{|c|c|c|}
\hline Country & Measures with potential impact on credit growth & Impact to date \\
\hline Portugal & $\begin{array}{l}\text { The authorities strengthened regulatory measures further by tightening } \\
\text { rules governing general provisions, large exposures, connected lending, } \\
\text { and capital adequacy. } \\
\text { However, in response to the rise in private sector bank borrowing, which } \\
\text { led to a surge in domestic demand and a widening of the current account } \\
\text { deficit financed by reduced holdings of government paper and increased } \\
\text { borrowing from abroad, the authorities took further measures: } \\
\text { (i) the authorities tightened further prudential and supervisory measures } \\
\text { to safeguard continued soundness of the financial sector, tightening of } \\
\text { capital requirements for housing loans with loans-to-value ratios } \\
\text { exceeding 75\% as well as tightening provisioning requirements for } \\
\text { consumer loans in early } 1999 \text {-with household credit growth rising } \\
\text { strongly from mid-1996 and helping finance the ongoing boom in } \\
\text { housing and durables consumption through imports; } \\
\text { (ii) new reporting requirements for liquidity monitoring purposes were } \\
\text { put in place, as well as guidance for controlling the reliance on short- } \\
\text { term market borrowing; } \\
\text { (iii) the authorities increased reporting and disclosure requirements for } \\
\text { banks on their risk management and control policies and practices to } \\
\text { enhance market discipline, undertook impact studies within the scope of } \\
\text { amending capital and provisioning requirements, and strengthened } \\
\text { coordination between different supervisory agencies of the financial } \\
\text { sector, forming in } 2000 \text { the National Council of Supervisors comprising } \\
\text { all financial sector supervisors. Promoting the coordination of the action, } \\
\text { facilitating and coordinating the exchange of information, and } \\
\text { formulating proposals for the regulation of matters undertaken by the } \\
\text { financial system's supervisory authorities are among the responsibilities } \\
\text { of the Council. Since its establishment, the Council has had regular } \\
\text { meetings. Supervision of financial conglomerates, anti-money laundering } \\
\text { rules, and structured deposits were some of the main issues discussed. }\end{array}$ & $\begin{array}{l}\text { - During the second half of the } 1990 \mathrm{~s} \text {, the marked } \\
\text { fall in interest rates contributed to the strong } \\
\text { growth in loans granted to the non-financial } \\
\text { private sector. These developments resulted in } \\
\text { large borrowing requirements, which translated } \\
\text { into a large current and capital account deficit. } \\
\text { - In } 1999 \text {, following the ECB interest rate rise, a } \\
\text { significant decline in credit growth was } \\
\text { observed. The economic slowdown that } \\
\text { culminated in the } 2003 \text { recession implied a } \\
\text { further reduction in the pace of growth of credit } \\
\text { to non-financial corporations and consumer } \\
\text { credits. However, housing loans' growth slowly } \\
\text { declined but persisted growing at a nominal rate } \\
\text { in excess of or around } 10 \text { percent. } \\
\text { Initially, banks financed the rapid credit growth } \\
\text { by disposing government debt holdings and } \\
\text { resorting to money market borrowing. Later in } \\
\text { the process, an increase in the maturity of bank } \\
\text { debt stock has been observed, in particular by } \\
\text { substituting interbank liabilities by longer-term } \\
\text { debt securities issues. In addition, the } \\
\text { possibilities opened by securitizations also } \\
\text { expanded the banks' liquidity management } \\
\text { options. }\end{array}$ \\
\hline Romania & 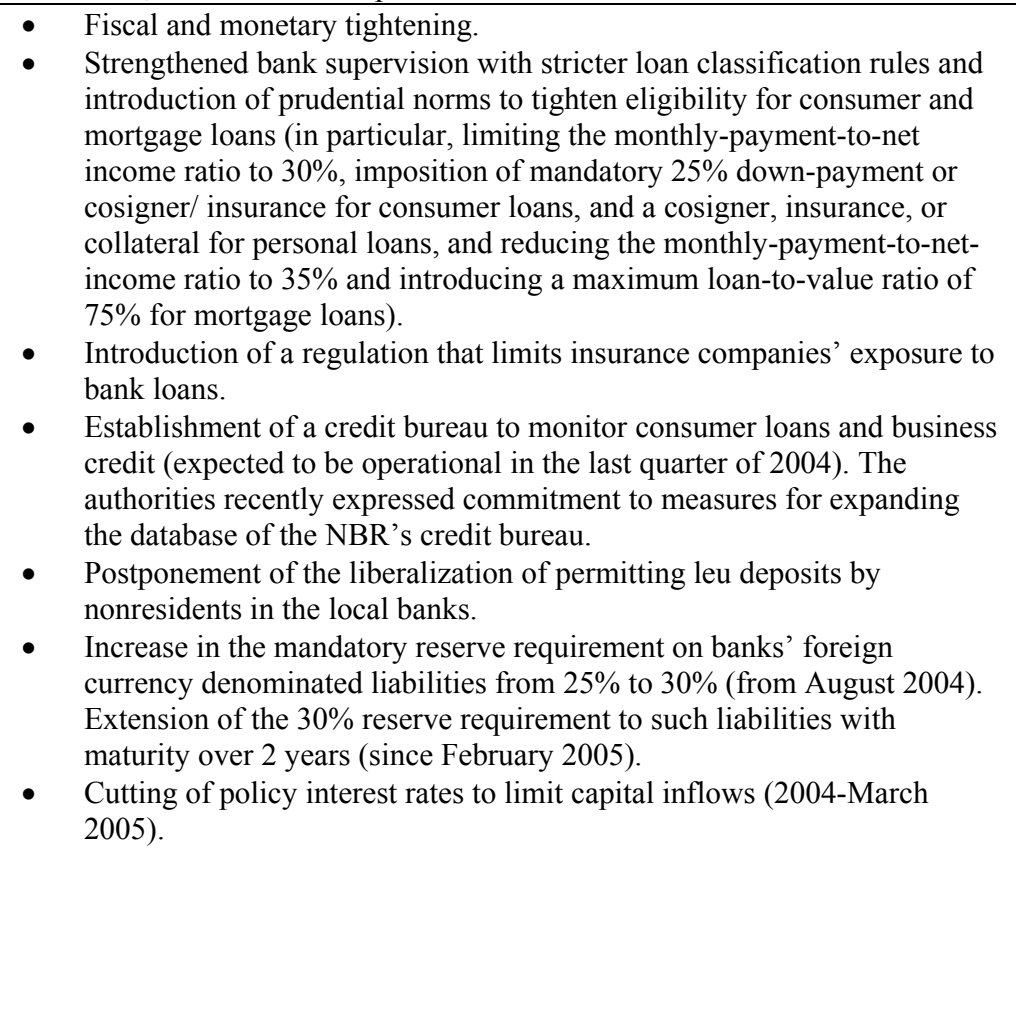 & $\begin{array}{l}\text { - Private sector credit growth has slowed from } \\
\text { August } 2003 \text { to April } 2004 \text {, but picked up again } \\
\text { afterwards. Growth in lei credit nearly came to a } \\
\text { halt, reflecting high interest rates and the effects } \\
\text { of the regulatory measures approved in late } 2003 \text {. } \\
\text { But, the FX-denominated credit has started to } \\
\text { pick up again, driven by strong mortgage } \\
\text { demand and a switch for some consumer } \\
\text { durables from lei to foreign currency credit, } \\
\text { though the end-August increase in RR on FX- } \\
\text { denominated loans seems to have helped slow } \\
\text { down its growth. About } 75 \% \text { of the growth is in } \\
\text { FX credit, out of which } 30 \% \text { is to households, } \\
\text { and } 70 \% \text { of this comprises mortgage loans. } \\
\text { The authorities remain alert to persistent strength } \\
\text { of credit growth in FX-denominated credit; } \\
\text { additional measures being contemplated (e.g. the } \\
\text { introduction of a marginal reserve requirement } \\
\text { on FX liabilities, higher provisioning } \\
\text { requirements against FX loans, introduction of } \\
\text { currency specific liquidity requirements at } \\
\text { binding levels) to slow credit growth. } \\
\text { - Cutting of policy interest rates through } 2004 \text { to } \\
\text { Mar } 2005 \text { has not have a major effect on lei- } \\
\text { denominated credit, owing to the large interest } \\
\text { rate differential between lei- and FX- } \\
\text { denominated loans and the expectations for } \\
\text { exchange rate appreciation. }\end{array}$ \\
\hline
\end{tabular}




\begin{tabular}{|c|c|c|}
\hline Country & Measures with potential impact on credit growth & Impact to date \\
\hline Serbia & $\begin{array}{l}\text { - Tightening of monetary policy by raising the required reserve ratio on all } \\
\text { dinar and enterprise FX deposits by } 3 \text { percentage points to } 21 \% \text { and } \\
\text { stepping up open market operations (August 2004) as a result of a strong } \\
\text { growth in bank credit to non-government sector (25.8\% real growth year } \\
\text { on year in July 2004). } \\
\text { The authorities issued a guideline tightening conditions for bank } \\
\text { consumer loans and requested the banks to adopt the guideline in } \\
\text { December 2004. They have also increased the capital adequacy ratio to } \\
10 \text { percent (effective March 2005) and broadened the reservable base to } \\
\text { include commercial banks' foreign borrowing (effective January 2005). } \\
\text { Specifically, the reservable base now includes the stock of all foreign } \\
\text { borrowing with a maturity of up to } 4 \text { years and all new foreign } \\
\text { borrowing independent if the maturity. In addition, they are currently } \\
\text { preparing a regulation on monitoring and managing credit risk resulting } \\
\text { from borrowers' exposure to exchange rate risk. Moreover, they are } \\
\text { exploring possibilities to start regulating and supervising leasing } \\
\text { companies. }\end{array}$ & $\begin{array}{l}\text { - The monetary tightening in mid-2004 did not } \\
\text { have any tangible impact on credit growth, which } \\
\text { accelerated further in the second half of the year, } \\
\text { reaching } 32.9 \text { percent in real terms in November. } \\
\text { This largely reflects the limited effectiveness of } \\
\text { monetary policy under the conditions of high } \\
\text { euroization, with } 67 \text { percent of total credit to } \\
\text { non-government being extended in foreign } \\
\text { currencies or indexed to foreign currencies, and } \\
\text { limited instruments for indirect monetary control. } \\
\text { - Given the fairly recent implementation of the } \\
\text { prudential measures, effectiveness can only be } \\
\text { assessed on a preliminary basis. Consumer } \\
\text { lending slowed down significantly in the three } \\
\text { months after the tightening measures. Credit to } \\
\text { nongovernment also slowed down, but in a less } \\
\text { pronounced manner. Banks remain vulnerable to } \\
\text { indirect FX risk. }\end{array}$ \\
\hline Spain & $\begin{array}{l}\text { - Dynamic provisioning: Concerned that banks' loan portfolios continued } \\
\text { to expand and that loan provisions were not keeping pace with potential } \\
\text { credit losses latent in new lending, the Bank of Spain introduced a new } \\
\text { "statistical provisioning" method, effective July 2000. The provision is } \\
\text { dynamic as it is envisaged to increase when specific provisions (i.e., } \\
\text { actual losses) for a year are lower than expected credit losses, and used } \\
\text { to set against specific provisions in years when specific provisions are } \\
\text { higher than expected credit losses. The statistical provisions are subject } \\
\text { to an upper limit and are not tax deductible. } \\
\text { With continued growth of housing credit, the authorities closely } \\
\text { monitored forward looking indicators of potential debt-servicing } \\
\text { difficulties, placing emphasis on continued vigilance, accompanied with } \\
\text { moral suasion, to ensure that credit institutions exercised adequate } \\
\text { caution, with effective credit approval and monitoring processes in place. }\end{array}$ & $\begin{array}{l}\text { The statistical provisions grew significantly over } \\
2000 \text { to } 2002 \text {. While growth of housing credit } \\
\text { slowed down temporarily from } 2000 \text { to } 2002 \text {, it } \\
\text { resumed its pace of growth, from } 14 \% \text { in } 2002 \text { to } \\
\text { about } 21 \% \text { in } 2004 \text {. The share in total credit to } \\
\text { the private sector from credit institutions rose } \\
\text { from } 28 \% \text { in } 1997 \text { to around } 34 \% \text { in } 2004 \text {. } \\
\text { - Dynamic provisioning was eliminated in } \\
\text { December } 2004 \text {. }\end{array}$ \\
\hline Ukraine & $\begin{array}{l}\text { - In response to a very rapid growth of banking system credit to the private } \\
\text { sector (from about } 33 \% \text { y/y in early } 2002 \text { to a peak of } 64 \% \text { in Nov 2003) } \\
\text { and with a view to reducing the credit risk in the economy and } \\
\text { strengthening the banking sector a number of prudential and supervisory } \\
\text { measures were taken: the minimum capital adequacy ratio was raised } \\
\text { from } 8 \text { percent to } 10 \text { percent (March } 2004 \text { ); resolutions were issued in } \\
\text { early April to increase and improve the quality of bank capital; loan } \\
\text { classification rules were somewhat strengthened; related-party lending } \\
\text { regulations were tightened by requiring lending to related-parties at } \\
\text { favorable terms to be fully matched by set-aside capital; methodological } \\
\text { guidelines were introduced on the inspection of banks based on a "Risk } \\
\text { Assessment System" in March } 2004 \text {. While they may not be specifically } \\
\text { aimed at addressing rapid credit growth, a number of measures taken } \\
\text { may contribute to strengthening creditor rights and integrity of the } \\
\text { financial system (a law on mortgages was passed, new civil and } \\
\text { commercial codes were adopted, amendments were made to anti-money } \\
\text { laundering (AML) legislation, and a regulator for nonbank financial } \\
\text { institutions established). } \\
\text { Limited monetary measures during } 2004 \text { : an increase in the overnight } \\
\text { refinancing rates, a change in reserve requirements to reduce the eligible } \\
\text { amount of vault cash in reserve requirements, elimination of the long- } \\
\text { term refinancing facility that could potentially distort the credit market, } \\
\text { and a change in the requirements for banks' access to NBU resources. }\end{array}$ & $\begin{array}{l}\text { - The rate of growth of bank credit slowed down } \\
\text { significantly from early } 2004 \text {, to about } 45 \% \text { as of } \\
\text { Oct } 2004 \text {, though still at a relatively high rate. }\end{array}$ \\
\hline
\end{tabular}

Sources: IMF Country Reports (Staff Reports and Selected Issues), Annual Reports of Central Banks, Kraft and Jankov (2005), and Fernandez de Lis, Pages, and Saurina (2000).

Explanation: $\mathrm{FX}=$ foreign exchange; $\mathrm{RR}=$ reserve requirements. 